Cochrane Database of Systematic Reviews

\title{
Comparison of routes for achieving parenteral access with a focus on the management of patients with Ebola virus disease (Review)
}

Ker K, Tansley G, Beecher D, Perner A, Shakur H, Harris T, Roberts I

Ker K, Tansley G, Beecher D, Perner A, Shakur H, Harris T, Roberts I.

Comparison of routes for achieving parenteral access with a focus on the management of patients with Ebola virus disease.

Cochrane Database of Systematic Reviews 2015, Issue 2. Art. No.: CD011386.

DOI: 10.1002/14651858.CD011386.pub2.

www.cochranelibrary.com 
TABLE OF CONTENTS

ABSTRACT

PLAIN LANGUAGE SUMMARY

SUMMARY OF FINDINGS

BACKGROUND

OBJECTIVES

METHODS

RESULTS

Figure 1.

Figure 2.

DISCUSSION

AUTHORS' CONCLUSIONS

ACKNOWLEDGEMENTS

REFERENCES

\section{CHARACTERISTICS OF STUDIES}

DATA AND ANALYSES

Analysis 1.1. Comparison 1 Intravenous versus intraosseous access, Outcome 1 Insertion failures.

Analysis 1.2. Comparison 1 Intravenous versus intraosseous access, Outcome 2 Insertion failures (subgroup analysis child vs adult).

Analysis 1.3. Comparison 1 Intravenous versus intraosseous access, Outcome 3 Time to infusion/placement.

Analysis 1.4. Comparison 1 Intravenous versus intraosseous access, Outcome 4 Average number of insertion attempts.

Analysis 1.5. Comparison 1 Intravenous versus intraosseous access, Outcome 5 Dislodgement of device during infusion. ........

Analysis 1.6. Comparison 1 Intravenous versus intraosseous access, Outcome 6 Local site reactions.

Analysis 1.7. Comparison 1 Intravenous versus intraosseous access, Outcome 7 Clinician's perception of ease/feasibility of administration.

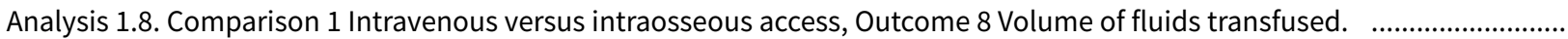

Analysis 1.9. Comparison 1 Intravenous versus intraosseous access, Outcome 9 Electrolyte level.

Analysis 1.10. Comparison 1 Intravenous versus intraosseous access, Outcome 10 Renal function.

Analysis 2.1. Comparison 2 Intravenous versus subcutaneous access, Outcome 1 Insertion failures.

Analysis 2.2. Comparison 2 Intravenous versus subcutaneous access, Outcome 2 Insertion failures (sensitivity analysis - trial(s) with adequate allocation concealment).

Analysis 2.3. Comparison 2 Intravenous versus subcutaneous access, Outcome 3 Insertion failures (subgroup analysis child vs adult).

Analysis 2.4. Comparison 2 Intravenous versus subcutaneous access, Outcome 4 Time to infusion/placement. ....................... Analysis 2.5. Comparison 2 Intravenous versus subcutaneous access, Outcome 5 Dislodgement of device during infusion. ...... Analysis 2.6. Comparison 2 Intravenous versus subcutaneous access, Outcome 6 Time with functional access (days). ............ Analysis 2.7. Comparison 2 Intravenous versus subcutaneous access, Outcome 7 Local site reactions.

Analysis 2.8. Comparison 2 Intravenous versus subcutaneous access, Outcome 8 Local site reactions (sensitivity analysis trial(s) with adequate allocation concealment).

Analysis 2.9. Comparison 2 Intravenous versus subcutaneous access, Outcome 9 Clinicians' scores of feasibility of insertion. .. Analysis 2.10. Comparison 2 Intravenous versus subcutaneous access, Outcome 10 Clinician's perception of difficulty of insertion.

Analysis 2.11. Comparison 2 Intravenous versus subcutaneous access, Outcome 11 Patients' discomfort.

Analysis 2.12. Comparison 2 Intravenous versus subcutaneous access, Outcome 12 Patients' discomfort (sensitivity analysis trial(s) with adequate allocation concealment).

Analysis 2.13. Comparison 2 Intravenous versus subcutaneous access, Outcome 13 Patient discomfort score. .........................

Analysis 2.14. Comparison 2 Intravenous versus subcutaneous access, Outcome 14 Mortality.

Analysis 2.15. Comparison 2 Intravenous versus subcutaneous access, Outcome 15 Mortality (sensitivity analysis - trial(s) with adequate allocation concealment).

Analysis 2.16. Comparison 2 Intravenous versus subcutaneous access, Outcome 16 Volume of fluids transfused. ...................

Analysis 2.17. Comparison 2 Intravenous versus subcutaneous access, Outcome 17 Volume of fluids transfused (sensitivity analysis - trial(s) with adequate allocation).

Analysis 2.18. Comparison 2 Intravenous versus subcutaneous access, Outcome 18 Electrolyte level. 
Analysis 2.19. Comparison 2 Intravenous versus subcutaneous access, Outcome 19 Markers of renal function.

Analysis 3.1. Comparison 3 Saphenous vein cutdown versus intraosseous access, Outcome 1 Insertion failures.

Analysis 3.2. Comparison 3 Saphenous vein cutdown versus intraosseous access, Outcome 2 Time to infusion/placement

(seconds).

APPENDICES

WHAT'S NEW

CONTRIBUTIONS OF AUTHORS 
[Intervention Review]

\section{Comparison of routes for achieving parenteral access with a focus on the management of patients with Ebola virus disease}

Katharine Ker ${ }^{1}$, Gavin Tansley², Deirdre Beecher ${ }^{1}$, Anders Perner ${ }^{3}$, Haleema Shakur ${ }^{2}$, Tim Harris ${ }^{4}$, Ian Roberts ${ }^{1}$

1Cochrane Injuries Group, London School of Hygiene \& Tropical Medicine, London, UK. ${ }^{2}$ Clinical Trials Unit, London School of Hygiene \& Tropical Medicine, London, UK. 3ITA 4131/Department of Intensive Care, Rigshospitalet, Copenhagen, Denmark. ${ }^{4}$ Department of Emergency Medicine, Royal London Hospital, Barts Health NHS Trust, London, UK

Contact: Katharine Ker, Cochrane Injuries Group, London School of Hygiene \& Tropical Medicine, Room 186, Keppel Street, London, WC1E 7HT, UK. katharine.ker@lshtm.ac.uk.

Editorial group: Cochrane Injuries Group.

Publication status and date: Edited (no change to conclusions), published in Issue 5, 2015.

Citation: Ker K, Tansley G, Beecher D, Perner A, Shakur H, Harris T, Roberts I. Comparison of routes for achieving parenteral access with a focus on the management of patients with Ebola virus disease. Cochrane Database of Systematic Reviews 2015, Issue 2. Art. No.: CD011386. DOI: 10.1002/14651858.CD011386.pub2.

Copyright ( 2015 The Cochrane Collaboration. Published by John Wiley \& Sons, Ltd.

\section{A B S T R A C T}

\section{Background}

Dehydration is an important cause of death in patients with Ebola virus disease (EVD). Parenteral fluids are often required in patients with fluid requirements in excess of their oral intake. The peripheral intravenous route is the most commonly used method of parenteral access, but inserting and maintaining an intravenous line can be challenging in the context of EVD. Therefore it is important to consider the advantages and disadvantages of different routes for achieving parenteral access (e.g. intravenous, intraosseous, subcutaneous and intraperitoneal).

\section{Objectives}

To compare the reliability, ease of use and speed of insertion of different parenteral access methods.

\section{Search methods}

We ran the search on 17 November 2014. We searched the Cochrane Injuries Group's Specialised Register, Cochrane Central Register of Controlled Trials (CENTRAL, The Cochrane Library), Ovid MEDLINE(R) In-Process \& Other Non-Indexed Citations, Ovid MEDLINE(R) Daily, Ovid MEDLINE(R) and Ovid OLDMEDLINE(R), Embase Classic + Embase (OvidSP), CINAHL (EBSCOhost), clinicaltrials.gov and screened reference lists.

\section{Selection criteria}

Randomised controlled trials comparing different parenteral routes for the infusion of fluids or medication.

\section{Data collection and analysis}

Two review authors examined the titles and abstracts of records obtained by searching the electronic databases to determine eligibility. Two review authors extracted data from the included trials and assessed the risk of bias. Outcome measures of interest were success of insertion; time required for insertion; number of insertion attempts; number of dislodgements; time period with functional access; local site reactions; clinicians' perception of ease of administration; needlestick injury to healthcare workers; patients' discomfort; and mortality. For trials involving the administration of fluids we also collected data on the volume of fluid infused, changes in serum electrolytes and markers of renal function. We rated the quality of the evidence as 'high', 'moderate', 'low' or 'very low' according to the GRADE approach for the following outcomes: success of insertion, time required for insertion, number of dislodgements, volume of fluid infused and needlestick injuries. 


\section{Main results}

We included 17 trials involving 885 participants. Parenteral access was used to infuse fluids in 11 trials and medications in six trials. None of the trials involved patients with EVD. Intravenous and intraosseous access was compared in four trials; intravenous and subcutaneous access in 11; peripheral intravenous and intraperitoneal access in one; saphenous vein cutdown and intraosseous access in one; and intraperitoneal with subcutaneous access in one. All of the trials assessing the intravenous method involved peripheral intravenous access.

We judged few trials to be at low risk of bias for any of the assessed domains.

Compared to the intraosseous group, patients in the intravenous group were more likely to experience an insertion failure (risk ratio (RR) $3.89,95 \%$ confidence interval $(\mathrm{Cl}) 2.39$ to 6.33 ; $n=242$; GRADE rating: low). We did not pool data for time to insertion but estimates from the trials suggest that inserting intravenous access takes longer (GRADE rating: moderate). Clinicians judged the intravenous route to be easier to insert ( $R R 0.15,95 \% \mathrm{Cl} 0.04$ to $0.61 ; n=182$ ). A larger volume of fluids was infused via the intravenous route (GRADE rating: moderate). There was no evidence of a difference between the two routes for any other outcomes, including adverse events.

Compared to the subcutaneous group, patients in the intravenous group were more likely to experience an insertion failure (RR $14.79,95 \%$ $\mathrm{Cl} 2.87$ to $76.08 ; \mathrm{n}=238$; GRADE rating: moderate) and dislodgement of the device (RR 3.78, 95\% $\mathrm{Cl} 1.16$ to $12.34 ; \mathrm{n}=67$; GRADE rating: low). Clinicians also judged the intravenous route as being more difficult to insert and patients were more likely to be agitated in the intravenous group. Patients in the intravenous group were more likely to develop a local infection and phlebitis, but were less likely to develop erythema, oedema or swelling than those in the subcutaneous group. A larger volume of fluids was infused into patients via the intravenous route. There was no evidence of a difference between the two routes for any other outcome.

There were insufficient data to reliably determine if the risk of insertion failure differed between the saphenous vein cutdown (SVC) and intraosseous method (RR 4.00, 95\% CI 0.51 to 31.13; GRADE rating: low). Insertion using SVC took longer than the intraosseous method (MD 219.60 seconds, $95 \% \mathrm{Cl} 135.44$ to 303.76 ; GRADE rating: moderate). There were no data and therefore there was no evidence of a difference between the two routes for any other outcome.

There were insufficient data to reliably determine the relative effects of intraperitoneal or central intravenous access relative to any other parenteral access method.

\section{Authors' conclusions}

There are several different ways of achieving parenteral access in patients who are unable meet their fluid requirements with oral intake alone. The quality of the evidence, as assessed using the GRADE criteria, is somewhat limited because of the lack of adequately powered trials at low risk of bias. However, we believe that there is sufficient evidence to draw the following conclusions: if peripheral intravenous access can be achieved easily, this allows infusion of larger volumes of fluid than other routes; but if this is not possible, the intraosseous and subcutaneous routes are viable alternatives. The subcutaneous route may be suitable for patients who are not severely dehydrated but in whom ongoing fluid losses cannot be met by oral intake.

A film to accompany this review can be viewed here (http://youtu.be/ArVPzkf93ng).

\section{PLAIN LANGUAGE SUMMARY}

Comparison of the different ways of giving fluids to patients who cannot drink enough, such as patients with Ebola virus disease

\section{Background}

Many patients with Ebola virus disease (EVD) die because they are dehydrated. Patients with EVD often experience severe vomiting and diarrhoea, which causes them to lose fluids that are difficult to replace by drinking alone. It is possible to give fluids in ways that do not involve the digestive tract; this is known as parenteral access. This includes infusing fluids into a vein (intravenously), into bone marrow (intraosseously), into fatty tissue under the skin (subcutaneously) or into the abdominal space (intraperitoneally). Giving fluids intravenously is the usual method, but can be problematic in patients with EVD because starting intravenous fluids can be difficult in very dehydrated patients, and infection control practices may make maintaining the infusion challenging. It is therefore useful if those caring for patients with EVD know the advantages and disadvantages of the other ways to give fluids, so that they can decide which is the most suitable for their patients.

\section{Searches for trials}

We carried out searches for trials comparing different parenteral access methods on 17 November 2014.

\section{Trial characteristics}

We found 17 trials involving 885 participants. None involved patients with EVD. Fifteen trials involved patients who required parenteral access for the infusion of fluids or medicines and two trials assessed different methods under simulated conditions, such as on a training manikin. Many trials were of poor quality. 


\section{Key results}

When the results of these trials were gathered together, they suggested that both the intraosseous and subcutaneous routes may be easier and quicker to insert into patients than the intravenous route, but more fluid can be given intravenously than by either the intraosseous or subcutaneous method. There has not been enough research into the intraperitoneal method to know how it compares to the other methods.

\section{Conclusions}

Healthcare workers caring for patients with EVD should be aware of the alternative ways of giving fluids. The trials we found were not of very high quality, therefore we need to be cautious when drawing conclusions based on their results. However, together they suggest if intravenous access can be achieved easily, then this should be used as it allows the infusion of larger volumes of fluid. However, if intravenous access is not possible, intraosseous and subcutaneous routes are alternatives that can be inserted quickly. Many of the trials conducted so far are of poor quality and none involved patients with EVD, therefore more trials should be carried out.

A film to accompany this review can be viewed here. 


\section{SUMMARY OF FINDINGS}

\section{Summary of findings for the main comparison. Intravenous versus intraosseous route for achieving parenteral access}

\section{Intravenous versus intraosseous route for achieving parenteral access}

Patient or population: adults or children requiring fluid delivered by a parenteral route (one study testing insertion and the volume of fluid delivered in manikins by practitioners wearing protective equipment was also included)

Settings: India (emergency unit) and USA (pre-hospital care)

Intervention: intravenous route

Comparison: intraosseous route

\begin{tabular}{|c|c|c|c|c|c|c|}
\hline \multirow[t]{3}{*}{ Outcomes } & \multicolumn{2}{|c|}{ Illustrative comparative risks* $(95 \% \mathrm{CI})$} & \multirow{3}{*}{$\begin{array}{l}\text { Relative effect } \\
(95 \% \mathrm{CI})\end{array}$} & \multirow{3}{*}{$\begin{array}{l}\text { No of partici- } \\
\text { pants } \\
\text { (studies) }\end{array}$} & \multirow{3}{*}{$\begin{array}{l}\text { Quality of the } \\
\text { evidence } \\
\text { (GRADE) }\end{array}$} & \multirow[t]{3}{*}{ Comments } \\
\hline & Assumed risk & Corresponding risk & & & & \\
\hline & Intraosseous route & Intravenous route & & & & \\
\hline \multirow{2}{*}{$\begin{array}{l}\text { Insertion fail- } \\
\text { ures }\end{array}$} & \multicolumn{2}{|l|}{ Study population } & \multirow{2}{*}{$\begin{array}{l}\text { RR } 3.89 \\
\text { (2.39 to } 6.33 \text { ) }\end{array}$} & \multirow{2}{*}{$\begin{array}{l}242 \\
(2 \mathrm{RCTs})\end{array}$} & \multirow{2}{*}{$\begin{array}{l}\oplus \oplus \odot \odot \\
\operatorname{LOW} 1,2\end{array}$} & \multirow[t]{2}{*}{-} \\
\hline & 12 per 100 & $\begin{array}{l}47 \text { per } 100 \\
(29 \text { to } 76)\end{array}$ & & & & \\
\hline $\begin{array}{l}\text { Time to infu- } \\
\text { sion/place- } \\
\text { ment }\end{array}$ & \multicolumn{2}{|c|}{$\begin{array}{l}\text { We did not combine data due to substantial variation in the average time } \\
\text { taken to insert parenteral access between trials. The estimates from all } 4 \\
\text { trials suggest that the IV route takes longer to insert than IO. Although we } \\
\text { are confident that the time to infusion is shorter with } 10 \text {, we cannot be cer- } \\
\text { tain about the size of the effect because the magnitude of the difference } \\
\text { varied considerably between trials }\end{array}$} & - & $\begin{array}{l}342 \\
(4 \mathrm{RCTs})\end{array}$ & $\begin{array}{l}\oplus \oplus \oplus \odot \\
\text { MODERATE } 1\end{array}$ & - \\
\hline \multirow{2}{*}{$\begin{array}{l}\text { Dislodgement } \\
\text { of device dur- } \\
\text { ing infusion }\end{array}$} & \multicolumn{2}{|l|}{ Study population } & \multirow{2}{*}{$\begin{array}{l}\text { RR } 0.53 \\
\text { (0.18 to } 1.55)\end{array}$} & \multirow{2}{*}{$\begin{array}{l}182 \\
(1 \mathrm{RCT})\end{array}$} & \multirow{2}{*}{$\begin{array}{l}\oplus \oplus \odot \odot \\
\text { LOW } 1,3\end{array}$} & \multirow[t]{2}{*}{-} \\
\hline & 113 per 1000 & $\begin{array}{l}60 \text { per } 1000 \\
(20 \text { to } 175)\end{array}$ & & & & \\
\hline $\begin{array}{l}\text { Needlestick in- } \\
\text { juries }\end{array}$ & No studies reported this outcome & No studies reported this outcome & - & NA & NA & - \\
\hline $\begin{array}{l}\text { Volume of fluid } \\
\text { infused }\end{array}$ & $\begin{array}{l}\text { The mean volume of fluid infused } \\
\text { (ml) in the } 10 \text { group was } 800\end{array}$ & $\begin{array}{l}\text { The mean volume of fluid infused ( } \mathrm{ml} \text { ) } \\
\text { in the IV group was } 400 \text { higher ( } 365 \\
\text { higher to } 434 \text { higher) }\end{array}$ & - & $\begin{array}{l}182 \\
(1 \mathrm{RCT})\end{array}$ & $\begin{array}{l}\oplus \oplus \oplus \odot \\
\text { MODERATE } 1\end{array}$ & - \\
\hline
\end{tabular}




\begin{tabular}{|c|c|c|c|c|c|c|}
\hline \multicolumn{7}{|c|}{$\begin{array}{l}{ }^{\star} \text { The basis for the assumed risk (e.g. the median control group risk across studies) is provided in footnotes. The corresponding risk (and its } 95 \% \text { confidence interval) is } \\
\text { based on the assumed risk in the comparison group and the relative effect of the intervention (and its } 95 \% \mathrm{CI} \text { ). } \\
\mathrm{Cl} \text { : confidence interval; IO: intraosseous; IV: intravenous; NA: not applicable; RCT: randomised controlled trial; RR: risk ratio }\end{array}$} \\
\hline \multicolumn{7}{|c|}{$\begin{array}{l}\text { GRADE Working Group grades of evidence } \\
\text { High quality: Further research is very unlikely to change our confidence in the estimate of effect. } \\
\text { Moderate quality: Further research is likely to have an important impact on our confidence in the estimate of effect and may change the estimate. } \\
\text { Low quality: Further research is very likely to have an important impact on our confidence in the estimate of effect and is likely to change the estimate. } \\
\text { Very low quality: We are very uncertain about the estimate. }\end{array}$} \\
\hline \multicolumn{7}{|c|}{$\begin{array}{l}\text { 1Downgraded one level for risk of bias: estimate based on trial(s) at unclear and/or high risk of bias for } \geq 1 \text { domain. } \\
\text { 2Downgraded one level for imprecision: estimate is statistically significant at the } 5 \% \text { level (P value }<0.001) \text {; however, the estimated required information size has not been achieved } \\
\text { and we cannot discount the possibility that it is a false positive. } \\
\text { 3Downgraded one level for imprecision: estimate based on few events and wide Cls that include both an increase and a decrease in risk. }\end{array}$} \\
\hline \multicolumn{7}{|c|}{ Intravenous versus subcutaneous route for achieving parenteral access } \\
\hline \multicolumn{7}{|c|}{$\begin{array}{l}\text { Patient or population: adults or children requiring parenteral access for infusion of fluids or medication } \\
\text { Settings: USA (children's unit) and Europe (older people care units) } \\
\text { Intervention: intravenous route } \\
\text { Comparison: subcutaneous route }\end{array}$} \\
\hline \multirow[t]{3}{*}{ Outcomes } & \multicolumn{2}{|l|}{ Illustrative comparative risks* $(95 \% \mathrm{CI})$} & \multirow{3}{*}{$\begin{array}{l}\text { Relative effect } \\
(95 \% \mathrm{Cl})\end{array}$} & \multirow{3}{*}{$\begin{array}{l}\text { No of partici- } \\
\text { pants } \\
\text { (studies) }\end{array}$} & \multirow{3}{*}{$\begin{array}{l}\text { Quality of the } \\
\text { evidence } \\
\text { (GRADE) }\end{array}$} & \multirow[t]{2}{*}{ Comments } \\
\hline & Assumed risk & Corresponding risk & & & & \\
\hline & Subcutaneous route & Intravenous route & & & & \\
\hline \multirow{2}{*}{$\begin{array}{l}\text { Insertion fail- } \\
\text { ures }\end{array}$} & Study population & & \multirow{2}{*}{$\begin{array}{l}\text { RR } 14.79 \\
\text { (2.87 to } 76.08 \text { ) }\end{array}$} & \multirow{2}{*}{$\begin{array}{l}238 \\
\text { (3 RCTs) }\end{array}$} & \multirow{2}{*}{$\begin{array}{l}\oplus \oplus \oplus \ominus \\
\text { MODERATE } 1,2\end{array}$} & \multirow{2}{*}{$\begin{array}{l}\text { IV rate calcu- } \\
\text { lated based on } \\
\text { an assumed } \\
\text { rate with the } \\
\text { subcutaneous } \\
\text { route generated } \\
\text { from correction } \\
\text { for zero events } \\
\text { (1.14 per } 100)\end{array}$} \\
\hline & $\begin{array}{l}\text { There were no insertion failures ob- } \\
\text { served with the subcutaneous route in } \\
\text { the studies }\end{array}$ & $\begin{array}{l}17 \text { per } 100 \\
\text { ( } 3 \text { to } 76)\end{array}$ & & & & \\
\hline $\begin{array}{l}\text { Time to infu- } \\
\text { sion/place- } \\
\text { ment }\end{array}$ & $\begin{array}{l}\text { The mean time to placement/start of } \\
\text { infusion in the subcutaneous group } \\
\text { was } 300 \text { seconds }\end{array}$ & $\begin{array}{l}\text { The mean time to place- } \\
\text { ment/start of infusion in the IV }\end{array}$ & - & $\begin{array}{l}96 \\
(1 \mathrm{RCT})\end{array}$ & $\begin{array}{l}\oplus \oplus \ominus \ominus \\
\text { LOW } 3,4\end{array}$ & - \\
\hline
\end{tabular}




\begin{tabular}{|c|c|c|c|c|c|c|c|}
\hline \multirow{3}{*}{\multicolumn{2}{|c|}{ 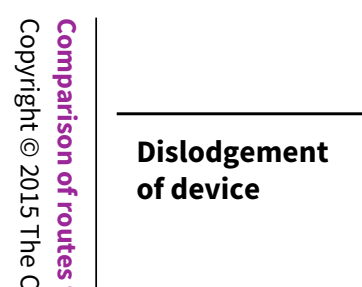 }} & \multicolumn{2}{|r|}{$\begin{array}{l}\text { group was } 120 \text { seconds longer } \\
\text { ( } 4.8 \text { shorter to } 244.8 \text { longer) }\end{array}$} & \multirow{3}{*}{$\begin{array}{l}\text { RR } 3.78 \\
\text { (1.16 to } 12.34)\end{array}$} & \multirow{3}{*}{$\begin{array}{l}67 \\
(1 \mathrm{RCT})\end{array}$} & \multirow{3}{*}{$\begin{array}{l}\oplus \oplus \oplus \ominus \\
\text { LOW } 3,4\end{array}$} & \multirow{3}{*}{-} \\
\hline & & \multicolumn{2}{|l|}{ Study population } & & & & \\
\hline & & 9 per 100 & \multirow{2}{*}{$\begin{array}{l}34 \text { per } 100 \\
\text { (10 to } 100) \\
\text { No studies reported this outcome }\end{array}$} & & & & \\
\hline \multirow{2}{*}{\multicolumn{2}{|c|}{ 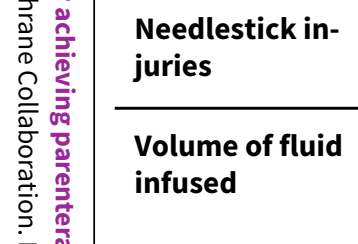 }} & No studies reported this outcome & & - & \multirow{2}{*}{ (4 RCTs) } & NA & - \\
\hline & & \multicolumn{2}{|c|}{$\begin{array}{l}\text { There was variation in the amount of fluid administered between trials, } \\
\text { therefore we did not pool data. The size and direction of the effects differed } \\
\text { across the } 4 \text { studies reporting data for this outcome }\end{array}$} & & & $\begin{array}{l}\oplus \oplus \ominus \ominus \\
\text { LOW } 3,5\end{array}$ & - \\
\hline \multirow{5}{*}{ 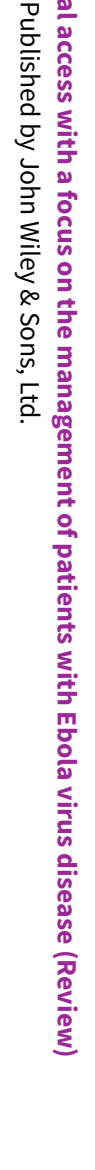 } & \multicolumn{7}{|c|}{$\begin{array}{l}\text { *The basis for the assumed risk (e.g. the median control group risk across studies) is provided in footnotes. The corresponding risk (and its } 95 \% \text { confidence interval) is } \\
\text { based on the assumed risk in the comparison group and the relative effect of the intervention (and its } 95 \% \mathrm{CI} \text { ). } \\
\mathrm{Cl} \text { : confidence interval; IV: intravenous; NA: not applicable; RCT: randomised controlled trial; RR: risk ratio }\end{array}$} \\
\hline & \multicolumn{7}{|c|}{$\begin{array}{l}\text { GRADE Working Group grades of evidence } \\
\text { High quality: Further research is very unlikely to change our confidence in the estimate of effect. } \\
\text { Moderate quality: Further research is likely to have an important impact on our confidence in the estimate of effect and may change the estimate. } \\
\text { Low quality: Further research is very likely to have an important impact on our confidence in the estimate of effect and is likely to change the estimate. } \\
\text { Very low quality: We are very uncertain about the estimate. }\end{array}$} \\
\hline & $\begin{array}{l}\text { 1Downgraded one } \\
\text { and we cannot dis } \\
\text { 2Not downgraded } \\
\text { 3Downgraded one } \\
\text { 4Downgraded one } \\
\text { 5Downgraded one }\end{array}$ & $\begin{array}{l}\text { evel for imprecision: estimate is statis } \\
\text { ount the possibility that it is a false p } \\
\text { or risk of bias as effect remained whe } \\
\text { evel for risk of bias: estimate based } \\
\text { evel for imprecision: effect borderlin } \\
\text { evel for inconsistency: variation in bc }\end{array}$ & $\begin{array}{l}\text { significant at the } 5 \% \text { level (P value }< \\
\text { e. Downgraded one level for risk of b } \\
\text { lysis was restricted to adequately co } \\
\text { l(s) at unclear and/or high risk of bia } \\
\text { ot statistically significant at the } 5 \% \text { l } \\
\text { agnitude }\left(\mathrm{I}^{2}>50 \% \text { ) and direction of }\right.\end{array}$ & $\begin{array}{l}.001) ; \text { however, } t \text { t } \\
\text { as: estimates bas } \\
\text { ncealed trials. } \\
\text { for } \geq 1 \text { domain. } \\
\text { vel and/or wide } \\
\text { ffects. }\end{array}$ & $\begin{array}{l}\text { estimated } \\
\text { on trials at }\end{array}$ & $\begin{array}{l}\text { informati } \\
\text { and/or hi }\end{array}$ & $\begin{array}{l}\text { s not been achieved } \\
\text { bias for } \geq 1 \text { domain. }\end{array}$ \\
\hline & \multicolumn{7}{|c|}{ Saphenous vein cutdown versus intraosseous route for achieving parenteral access } \\
\hline & \multicolumn{7}{|c|}{$\begin{array}{l}\text { Patient or population: trainee paramedics using both methods of gaining parenteral access on cadavers } \\
\text { Settings: USA (training laboratory) } \\
\text { Intervention: saphenous vein cutdown } \\
\text { Comparison: intraosseous }\end{array}$} \\
\hline
\end{tabular}




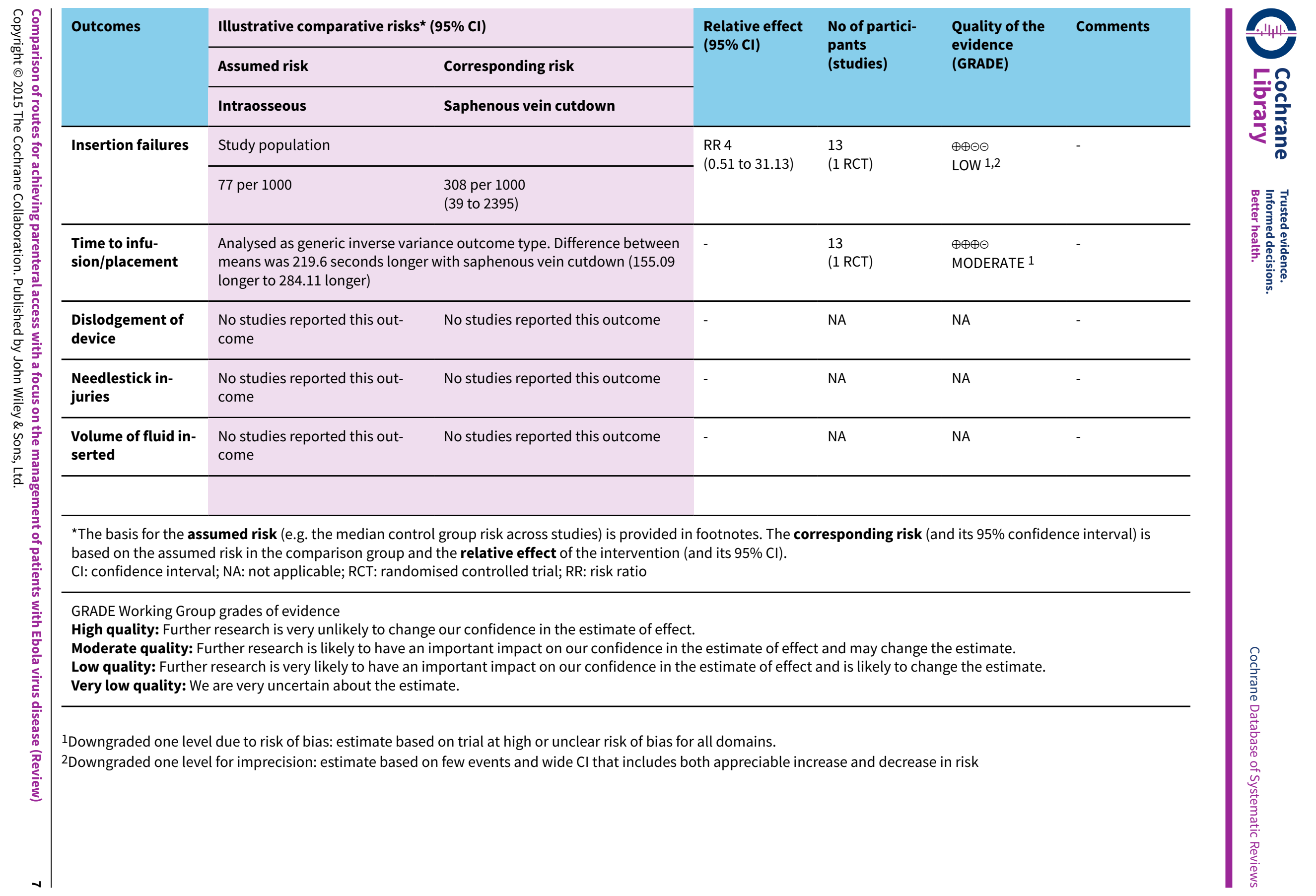




\section{B A C K G R O U N D}

\section{Description of the condition}

Ebola virus disease (EVD) is a severe infection with a high casefatality rate (WHO Ebola Response Team 2014). West Africa is currently (November 2014) experiencing the largest recorded outbreak of EVD with many hundreds of new cases per week (WHO Ebola Response Team 2014). EVD is characterised by sudden onset of fever followed by nausea, vomiting and diarrhoea. The associated fluid loss, which can be as much as five to 10 litres per day (Kreuels 2014; Ribner 2014), leads to electrolyte abnormalities and profound intravascular volume depletion (Feldmann 2011; Sanchez 2006). Case series show that in people with fatal EVD, blood levels of urea and creatinine increase over time, which may be a consequence of dehydration (Schieffelin 2014). Fluid administration is therefore recommended as a key part of supportive care to reduce mortality in patients with EVD (WHO 2014).

\section{Description of the intervention}

Many patients with EVD have nausea, difficulty swallowing and severe vomiting, which limit the usefulness of oral rehydration. Similarly, severe diarrhoea limits the usefulness of rectal fluid administration. In these patients, parenteral fluids can be given to prevent and treat dehydration.

There are four main ways of achieving parenteral access to administer fluids: intravenous, intraosseous, subcutaneous and intraperitoneal.

- Intravenous access involves the delivery of fluids or medications directly into a vein. There are two types of venous access central and peripheral. Central venous catheters involve placing a cannula into one of the large veins as it enters the body's trunk (most commonly the internal jugular, subclavian or femoral veins) and advancing until the tip of the catheter sits in the superior vena cava, or the iliac vein in the case of the femoral catheter. Peripheral cannulae are placed in a limb or (rarely) the scalp;

- Intraosseous access involves the insertion of a needle into the bone marrow (usually in the tibia or the humerus, or less commonly in the pelvis or sternum) to which an infusion line is connected. It is often used in patients for whom intravenous access is difficult to achieve, such as those with collapsed peripheral veins and young children. Intraosseous needles can be inserted manually, although the use of mechanical insertion devices, such as the BIG Bone Injection Gun ${ }^{\circledR}$ and Arrow $^{\circledR}$ EZ-IO ${ }^{\circledR}$ Intraosseous Vascular Access System, have become common. A pressurised fluid bag is required to ensure that the fluid runs;

- Subcutaneous access involves the insertion of a needle or catheter into the subcutaneous tissue that lies beneath the dermis and epidermis layers. Hyaluronidase may be given to improve absorption of infused substances into the circulation. Common sites for subcutaneous infusion are the abdomen, thigh and upper arm;

- Intraperitoneal access involves placing a catheter through the abdominal wall and the delivery of fluids into the peritoneal cavity, in similarity with peritoneal dialysis. This approach has been used in resource poor settings to resuscitate children with severe diarrhoea due to cholera infection (Mahalanabis 1970).
The intravenous route is the most commonly used method for administering fluids (Waitt 2004). However, securing intravenous access can be technically difficult in sick and dehydrated patients and is likely to be particularly challenging for healthcare workers obliged to wear personal protective equipment (PPE). Staff shortages and limitation of time spent at the bedside due to the challenge of wearing PPE for long periods in a hot environment may also frustrate efforts to achieve intravenous access in large numbers of sick patients (Fowler 2014). Securing parenteral access may also present risks to healthcare workers, e.g. needlestick injury or inadvertent contact with body fluids associated with insertion or dislodgement of parenteral access. For these reasons, an understanding of the relative merits of alternative routes (intravenous, intraosseous, subcutaneous or intraperitoneal) for achieving parenteral access could be important for the management of patients with EVD. The different approaches are likely to vary in terms of ease of insertion and effectiveness for fluid replacement.

\section{Why it is important to do this review}

Due to the large number of cases and resource constraints, it is essential that parenteral access in patients with EVD can be achieved quickly and maintained with minimal clinical intervention. We have therefore conducted a systematic review of randomised controlled trials comparing alternative routes for achieving parenteral access to assess their effectiveness and safety in terms of ease of insertion and effectiveness for fluid replacement.

This Cochrane review has been prompted by the ongoing EVD crisis in West Africa and the need to identify ways to improve the medical care of those affected. However, we have not limited the inclusion criteria to patients with EVD as we anticipated that it was unlikely that we would find any trial research conducted in this specific patient group. We believe that evidence derived from trials involving patients who require insertion of parenteral access for other indications is relevant to the management of patients with EVD, as well as to the wider range of patients who require parenteral infusions.

\section{O B JECTIVES}

To compare the reliability, ease of use and speed of insertion of different parenteral access methods.

\section{METHO DS}

\section{Criteria for considering studies for this review}

\section{Types of studies}

Randomised controlled trials.

Eligible trials were those judged to have assigned participants using a method of random allocation (e.g. computer-generated randomisation, random numbers table or drawing lots) or a quasirandom method of allocation (e.g. alternation, date of birth or case record number) (definition adapted from Box 6.3.a in Lefebvre 2011).

\section{Types of participants}

People of any age in whom insertion of a parenteral access method is attempted for the purpose of infusing fluids or medication. 
Trials involving the insertion of parenteral access under simulated conditions, such as using manikins or cadavers in which healthcare workers are randomly allocated to insert different parenteral access methods, were also eligible.

\section{Types of interventions}

We considered the following parenteral access methods: intravenous (central venous access and peripheral venous access), intraperitoneal, subcutaneous and intraosseous (using both manual and mechanical methods). We planned to explore the effects of central venous access and peripheral venous access separately.

Only trials comparing two or more of the above parenteral routes were eligible.

\section{Types of outcome measures}

\section{Primary outcomes}

- Success of route placement ('success'/'failure' as defined in the individual trial).

\section{Secondary outcomes}

- Time to infusion/placement.

- Average number of insertion attempts.

- Dislodgement of device during infusion.

- Time period with functional access.

- Local site reactions (e.g. infusion site pain, swelling, infection).

- Clinician's perception of ease of administration.

- Needlestick injury to healthcare workers.

- Patient's discomfort.

- Mortality.

For trials assessing parenteral routes for fluid administration, we extracted data on the following outcomes:

- Volume of fluid infused.

- Electrolyte levels and renal function (changes in serum sodium, potassium, urea and creatinine).

\section{Search methods for identification of studies}

In order to reduce publication and retrieval bias we did not restrict our search by language, date or publication status.

\section{Electronic searches}

We searched the following databases:

1. Cochrane Injuries Group Specialised Register (17 November 2014);

2. Cochrane Central Register of Controlled Trials (CENTRAL, The Cochrane Library) (issue 10 of 12, 2014);

3. Ovid MEDLINE(R), Ovid MEDLINE(R) In-Process \& Other Non-Indexed Citations, Ovid MEDLINE(R) Daily and Ovid OLDMEDLINE(R) (1946 to 17 November 2014);

4. Embase Classic + Embase (OvidSP) (1947 to 17 November 2014);

5. CINAHL Plus (EBSCO) (1937 to 17 November 2014);

6. Clinicaltrials.gov (www.clinicaltrials.gov) (accessed 17 November 2014).
We adapted the MEDLINE search strategy (Appendix 1 ) as necessary for each of the other databases: the added study filter is a modified version of the Ovid MEDLINE(R) Cochrane Highly Sensitive Search Strategy for identifying randomised trials (Lefebvre 2011). For the Embase search strategy we added the study design terms used by the UK Cochrane Centre (Lefebvre 2011).

\section{Searching other resources}

We screened the reference lists of the eligible trials and review articles for further potentially eligible studies. We also searched the internet using the Google search engine (www.google.com) with selected terms from the search strategy to identify further unpublished or grey literature.

\section{Data collection and analysis}

\section{Selection of studies}

Two review authors (KK and DB, IR or HS) independently examined the records identified from the search and screened them by reviewing the title and abstract. We obtained the full texts of potentially eligible studies and two review authors assessed whether each study met the inclusion criteria. We resolved disagreements through discussion or by asking a third review author (IR).

\section{Data extraction and management}

Two review authors (KK and GT) independently extracted data using a data extraction form designed specifically for the review. We extracted data on the following:

- patient characteristics (including age, sex, indication for parenteral access);

- intervention characteristics (including description of parenteral routes, use of PPE);

- trial methods (specifically information for 'Risk of bias' assessment);

- outcome data.

We resolved any disagreements about the extracted data by discussion or by asking a third review author (IR).

\section{Assessment of risk of bias in included studies}

Two review authors ( $K K$ and GT) assessed the risk of bias in the included trials using The Cochrane Collaboration's 'Risk of bias' tool, as described by Higgins 2011a. We assessed the following domains for each trial: sequence generation, allocation concealment, blinding (participants, personnel and outcome assessment), incomplete outcome data and selective outcome reporting. We completed a 'Risk of bias' table, incorporating a description of the trial against each of the domains and a judgement of the risk of bias, as follows: 'low risk', 'high risk' or 'unclear risk' of bias.

For the 'blinding of outcome assessment' and 'incomplete outcome data' domains, we assessed the risk of bias by outcome group as follows.

- Outcomes related to parenteral route insertion (success of route placement; number of insertion attempts; dislodgement of device during infusion; time period with functional access). 
- Clinical outcomes (sodium; potassium; urea; creatinine; mortality).

- Subjective outcomes (local site reactions, complications; clinician's perception of ease of administration; volume of fluid infused; needlestick injury to healthcare workers; patient's discomfort).

\section{Measures of treatment effect}

For binary outcome data, we calculated risk ratios and 95\% confidence intervals $(\mathrm{Cl})$ and for continuous outcome data we calculated the mean difference and $95 \% \mathrm{Cl}$ for each trial. In a number of trials, summary continuous data were presented as medians and ranges; in these cases, for the purpose of metaanalysis, we estimated the corresponding means and standard deviations using the method described in Hozo 2005 (Appendix 2).

\section{Unit of analysis issues}

For cross-over trials, we extracted effect estimates from an appropriate paired analysis from the trial reports or we calculated these where possible. We included these estimates in the metaanalysis using the generic inverse variance method. However, if a cross-over trial presented data according to the treatment group, we analysed the results from both periods of the cross-over trial as if they had originated from a parallel design. This latter approach leads to a unit of analysis error, causing the $\mathrm{Cls}$ to be too wide and the trial to receive too little weight. However, we think that the resulting conservative estimates are preferable to omitting all such data from the analyses.

Cluster-randomised controlled trials that reported effect estimates and confidence intervals derived from an appropriate analysis (e.g. generalised estimating equations or multi-level modelling) would have been included in the meta-analysis using the generic inverse variance method. Alternatively, if any such trial had analysed data at the level of the participant rather than at the cluster level, we would have attempted an approximate analysis as described in Higgins 2011b, assuming an estimate of the intracluster correlation coefficient was available.

For trials involving multiple intervention groups, we followed the approach described in Higgins 2011b. Where there were multiple groups receiving the same parenteral access method, we combined these to create a single pair-wise comparison with a group receiving an alternative parenteral method.

\section{Dealing with missing data}

We analysed trial results on an intention-to-treat basis where the necessary data were available. Where data in the trial reports were not presented on an intention-to-treat basis but information about exclusions was presented, we 're-included' exclusions to allow for inclusion in the meta-analysis as intention-to-treat. Otherwise, we used the data available from the trial report and conducted an available-case analysis.

\section{Assessment of heterogeneity}

We assessed trial characteristics in terms of participants, interventions and outcomes for clinical heterogeneity.

We examined statistical heterogeneity by visual inspection of forest plots, and by using the $\mathrm{I}^{2}$ statistic and the Chi ${ }^{2}$ test. The $\mathrm{I}^{2}$ statistic describes the percentage of total variation across studies due to heterogeneity rather than chance. A value of $0 \%$ indicates no observed heterogeneity and larger values show increasing heterogeneity; substantial heterogeneity is considered to exist when $\mathrm{I}^{2}$ is greater than $50 \%$ (Deeks 2011). For the $\mathrm{Chi}^{2}$ test, we used a $P$ value of less than 0.10 to indicate the presence of statistically significant heterogeneity.

We anticipated that differences in the definition of the primary outcome, 'success'/'failure' of insertion, between individual trials might be a potential source of heterogeneity.

\section{Assessment of reporting biases}

We planned to investigate the presence of reporting (publication) bias using funnel plots if there were at least 10 trials for the same outcome in the analysis.

\section{Data synthesis}

Where we judged the included trials to be too clinically heterogeneous to pool, we described the results narratively. When we considered a pooled analysis to be appropriate, we combined effect estimates using the fixed-effect model (also known as the weighted-average method). We consider this approach to be preferable to the random-effects model, which can give too much weight to smaller trials that are often of poorer methodological quality.

\section{Required sample size}

Using TSA - Trial Sequential Analysis 0.9 Beta software, we estimated that a total sample size of 1388 would be required for the meta-analysis of our primary outcome to detect an intervention effect reliably. This estimate is based on an assumed baseline event rate of $50 \%$, with $90 \%$ power to detect a clinically relevant difference of $20 \%$ at the $5 \%$ significance level, adjusted for heterogeneity anticipated at $\mathrm{I}^{2}=25 \%$.

\section{Subgroup analysis and investigation of heterogeneity}

We conducted subgroup analyses to examine whether the effects of the parenteral route of fluid administration varied by age of patient (child versus adult) and use of PPE (PPE versus no PPE), assuming that there was at least one trial in each subgroup.

\section{Sensitivity analysis}

We conducted sensitivity analyses to quantify the effects when restricted to trials with adequate allocation concealment, assuming that there was at least one trial contributing data to the analysis.

\section{Summary of findings}

We have also included the results of the review for the following outcomes in 'Summary of findings' tables. We included information about the following outcomes:

- success of route placement;

- time to placement/start to infusion;

- dislodgement of device during infusion;

- volume of fluid infused;

- needlestick injuries.

We used GRADEpro 2014 to prepare the tables. We judged the overall quality of the evidence for each outcome as 'high', 
'moderate', 'low' or 'very low' according to the GRADE approach (Schünemann 2011). We considered the following:

- impact of the risk of bias of individual trials;

- precision of the pooled estimate;

- inconsistency or heterogeneity (clinical, methodological and statistical);

- indirectness of evidence;

- impact of selective reporting and publication bias on effect estimate.

\section{RES U L T S}

\section{Description of studies}

\section{Results of the search}

The trial selection process is summarised in Figure 1. The combined search strategy identified 1276 records, of which we judged 36 to be potentially eligible and obtained the full texts. After a fulltext review, we included 17 trials in the review, which involved 21 eligible pair-wise comparisons. 
Figure 1. Study flow diagram.

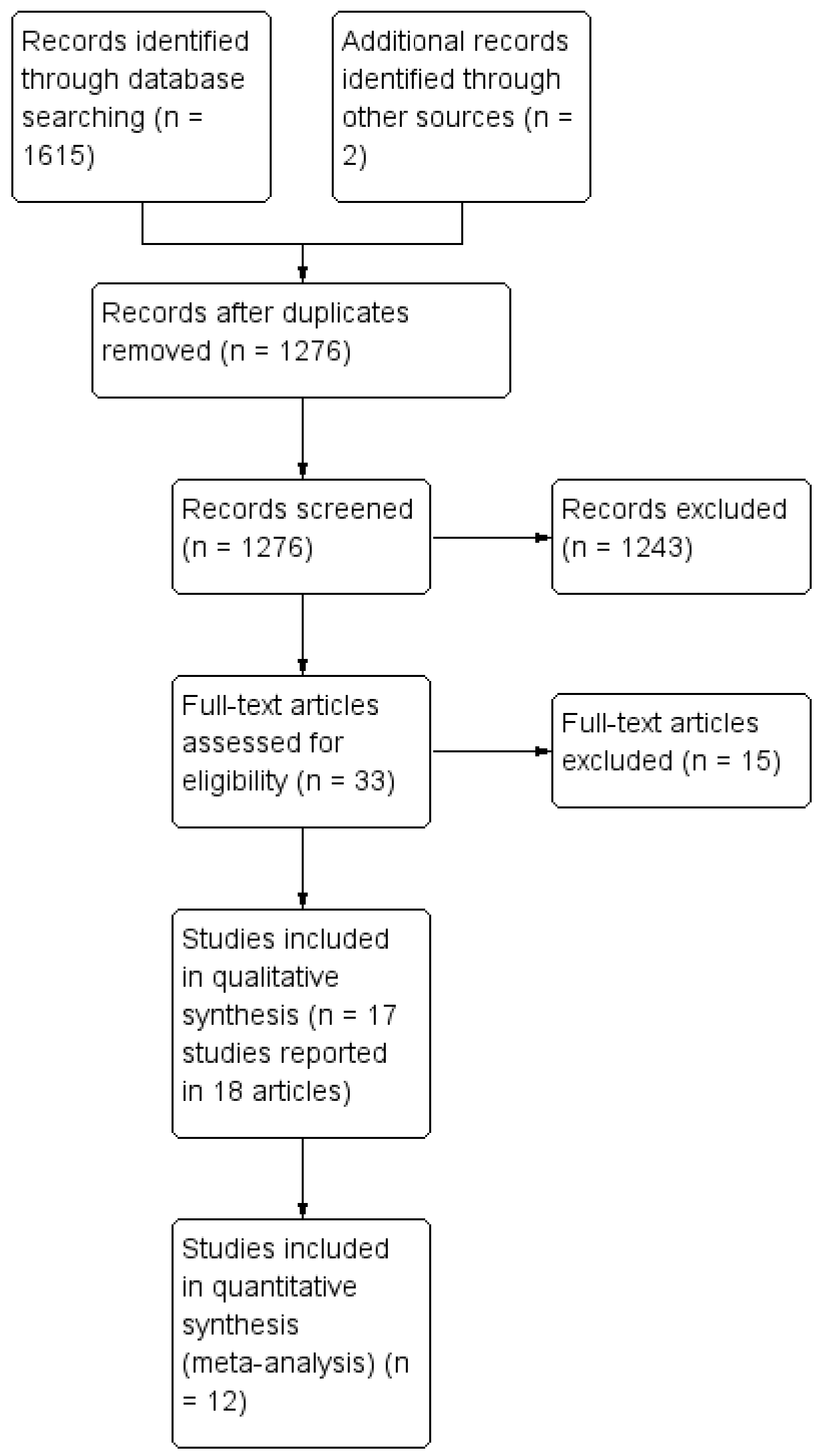




\section{Included studies}

Full details of each trial are presented in the Characteristics of included studies table; a summary is given below.

\section{Design}

Ten trials were randomised, parallel-group trials and seven were randomised, cross-over trials.

Of the seven cross-over trials, five involved a two-period comparison, one a four-period comparison and one a three-period comparison.

\section{Sample sizes}

The 17 trials included a combined total of 885 participants, of whom 847 were patients requiring parenteral access and 38 were health personnel who were attempting parenteral access under simulated conditions. The median sample size was 37 (range 6 to 182). One hundred and five participants were included in the cross-over trials and therefore acted as their own control.

\section{Setting and participants}

One trial was multicentre, conducted in 11 European countries. The remaining trials were conducted in Denmark $(n=1)$, France $(n=5)$, Germany $(n=1)$, India $(n=1)$, Spain $(n=1)$, Sweden $(n=1)$, the USA $(n=3)$ and the UK $(n=3)$.

None of the included trials involved patients with Ebola virus disease (EVD) or were conducted in the context of a similar medical emergency. Instead, the included trials were conducted in the following clinical settings: two involved the treatment of children with dehydration in hospital; one involved patients receiving a bone marrow transplant; six involved hospitalised elderly patients requiring parenteral fluids to maintain or restore hydration; three involved the infusion of insulin in patients with diabetes; one involved patients with multifocal neuropathy being treated with immunoglobulin; one involved patients with malignant disease in an oncology department; one involved paramedics attending out-of-hospital cardiac arrests; one involved paramedic trainees attempting parenteral access on cadavers in a hospital training laboratory; and one involved doctors and nurses attempting parenteral access on manikins in a pre-hospital department.

Fifteen trials compared different parenteral routes in patients; 14 involved adults and one involved children (Banerjee 1994). The other two studies by Lamhaut et al and Hubble 2001 used a cross-over design to assign medical personnel to attempt different parenteral routes. Training manikins were used in Lamhaut and cadavers in Hubble 2001.

The purpose of the parenteral access was for the infusion of fluids in 11 trials (Banerjee 1994; Challiner 1994; Dardaine 1995; Delamaire 1992; Duems Noriega 2014; Hubble 2001; Lamhaut 2010 (no PPE); Lamhaut 2010 (with PPE); O'Keeffe 1996; Reades 2011; Slesak 2003; Spandorfer 2005), and for the infusion of medication (including insulin, bone marrow, immunoglobulin and bleomycin) in six trials (Boullu-Sanchis 2006; Hägglund 1998; Harbo 2009; Harvey 1987; Liebl 2009; Selam 1983).

\section{Interventions}

The included trials compared the following:
- Intravenous access versus intraosseous access, four trials (Banerjee 1994; Hägglund 1998; Lamhaut 2010 (no PPE); Lamhaut 2010 (with PPE); Reades 2011).

- Intravenous access versus subcutaneous access, 11 trials (Boullu-Sanchis 2006; Challiner 1994; Dardaine 1995; Delamaire 1992; Duems Noriega 2014; Harbo 2009; Harvey 1987; O'Keeffe 1996; Selam 1983; Slesak 2003; Spandorfer 2005).

- Intravenous access versus intraperitoneal access, one trial (Selam 1983).

- Saphenous vein cutdown versus intraosseous access, one trial (Hubble 2001).

- Intraperitoneal access versus subcutaneous access, one trial (Selam 1983).

All of the trials assessing the intravenous method involved peripheral intravenous access.

One cross-over trial by Lamhaut et al compared intravenous and intraosseous insertion with and without the wearing of PPE. For the purpose of the meta-analysis, we considered separately the data for the comparison of intravenous and intraosseous insertion without PPE (Lamhaut 2010 (no PPE)) and with PPE (Lamhaut 2010 (with PPE)).

The trial by Reades et al compared intravenous access with two intraosseous groups; one involved insertion into the humerus and the other into the tibia (Reades 2011). For the purpose of the metaanalysis, we combined the data from the two intraosseous groups to derive a single comparison with the intravenous group.

The cross-over trial by Selam et al compared three parenteral methods for administering insulin - intravenous, subcutaneous and intraperitoneal (Selam 1983). We considered separately the results from the three single pair-wise comparisons (intravenous versus subcutaneous, intravenous versus intraperitoneal, and subcutaneous versus intraperitoneal) in this review.

\section{Outcomes}

The trials reporting data on the outcomes of interest are as follows:

- Success of route of insertion, six trials.

- Time to infusion/placement, four trials.

- Number of insertion attempts, one trial.

- Dislodgement of device during infusion, two trials.

- Time period with functional access, one trial.

- Local site reactions (e.g. erythema, oedema, swelling, infection), 11 trials.

- Clinician's perception of ease of administration, three trials.

- Needlestick injury to healthcare workers; no trials.

- Patient's discomfort (pain or discomfort); five trials.

- Mortality, two trials.

- Volume of fluid infused, five trials.

- Serum sodium, two trials.

- Serum potassium, one trial.

- Urea, two trials.

- Creatinine, three trials. 


\section{Excluded studies}

A list of excluded studies with the reasons for their exclusion is presented in Characteristics of excluded studies.

\section{Risk of bias in included studies}

Our judgements regarding each 'Risk of bias' item for each included trial are presented in Figure 2. 
Figure 2. 'Risk of bias' summary: review authors' judgements about each risk of bias item for each included study.

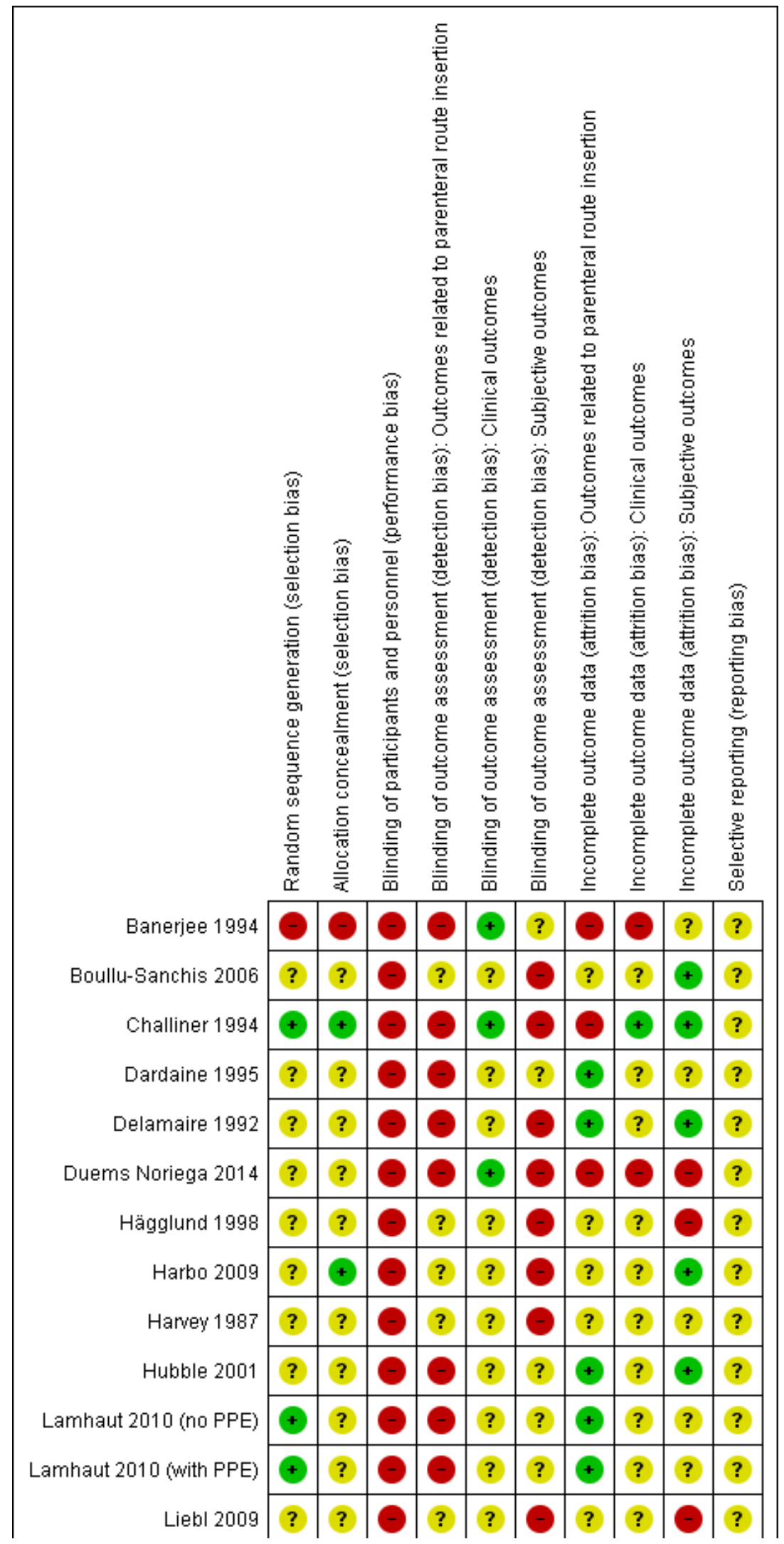


Figure 2. (Continued)

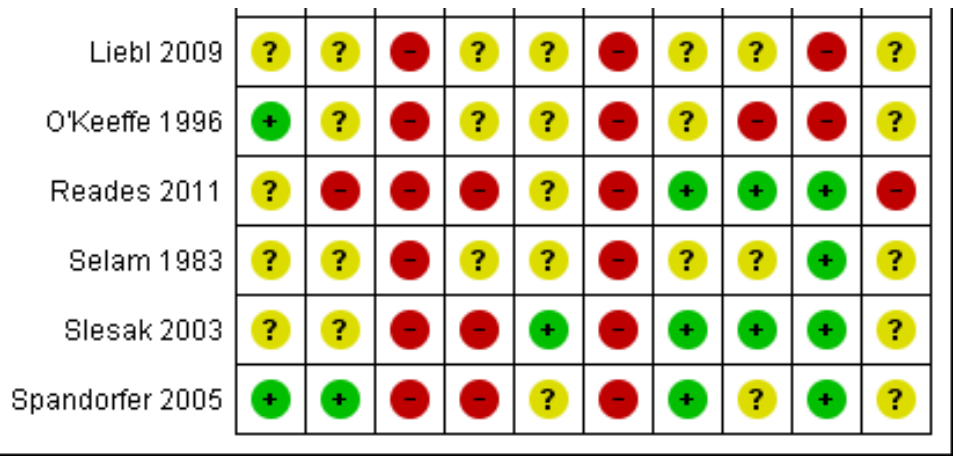

\section{Allocation}

\section{Sequence generation}

One trial alternately assigned patients into groups and we judged it to be at high risk of bias (Banerjee 1994). Four trials used an adequate method of sequence generation and we judged them to be at low risk of bias; of these, one trial referred to a random numbers table (O'Keeffe 1996), and three used computer-generated randomisation (Challiner 1994; Lamhaut 2010 (no PPE); Lamhaut 2010 (with PPE); Spandorfer 2005). We rated the remaining 12 trials as unclear due to insufficient information (Boullu-Sanchis 2006; Dardaine 1995; Delamaire 1992; Duems Noriega 2014; Hägglund 1998; Harbo 2009; Harvey 1987; Hubble 2001; Liebl 2009; Reades 2011; Selam 1983; Slesak 2003).

\section{Allocation concealment}

We judged allocation to have been inadequately concealed and at high risk of bias in two trials (Banerjee 1994; Reades 2011). Two trials used a method of central allocation (Harbo 2009; Spandorfer 2005), and one trial used sequentially numbered, sealed envelopes (Challiner 1994); we considered all three to be adequately concealed and at low risk of bias. We rated the remaining 12 trials as unclear due to insufficient information (Boullu-Sanchis 2006; Dardaine 1995; Delamaire 1992; Duems Noriega 2014; Hägglund 1998; Harvey 1987; Hubble 2001; Lamhaut 2010 (no PPE); Lamhaut 2010 (with PPE); Liebl 2009; O'Keeffe 1996; Selam 1983; Slesak 2003).

\section{Blinding}

\section{Blinding of participants and personnel}

Due to the nature of the interventions under study, it was not feasible for participants and personnel to be blinded to allocation status and we judged all 17 trials to be at high risk of bias, although it is unclear in which direction the results would have been biased.

\section{Blinding of outcome assessment}

\section{Outcomes related to parenteral route insertion}

We judged that measurement of these outcomes was likely to have been influenced by lack of blinding so we judged all 10 trials reporting data on these outcomes to be at high risk of bias (Banerjee 1994; Challiner 1994; Dardaine 1995; Delamaire 1992; Duems Noriega 2014; Hubble 2001; Lamhaut 2010 (no PPE); Lamhaut 2010 (with PPE); Reades 2011; Slesak 2003; Spandorfer 2005).

\section{Clinical outcomes}

We judged that measurement of these outcomes was not likely to have been influenced by lack of blinding so we judged all four trials reporting data on these outcomes to be at low risk of bias (Banerjee 1994; Challiner 1994; Duems Noriega 2014; Slesak 2003).

\section{Subjective outcomes}

We judged that measurement of these outcomes was likely to have been influenced by lack of blinding so we judged all 13 trials reporting data on these outcomes to be at high risk of bias (BoulluSanchis 2006; Challiner 1994; Delamaire 1992; Duems Noriega 2014; Hägglund 1998; Harbo 2009; Harvey 1987; Liebl 2009; O'Keeffe 1996; Reades 2011; Selam 1983; Slesak 2003; Spandorfer 2005).

\section{Incomplete outcome data}

\section{Outcomes related to parenteral route insertion}

Of the 11 trials reporting data on one or more of these outcomes, we judged three to be at high risk of bias (Banerjee 1994; Challiner 1994; Duems Noriega 2014), and eight at low risk of bias (Dardaine 1995; Delamaire 1992; Hubble 2001; Lamhaut 2010 (no PPE); Lamhaut 2010 (with PPE); Reades 2011; Slesak 2003; Spandorfer 2005).

\section{Clinical outcomes}

Of the six trials reporting data on one or more of these outcomes, we judged three to be at high risk of bias (Banerjee 1994; Duems Noriega 2014; O'Keeffe 1996), and three at low risk of bias (Challiner 1994; Reades 2011; Slesak 2003).

\section{Subjective outcomes}

Of the 13 trials reporting data on one or more of these outcomes, we judged four to be at high risk of bias (Duems Noriega 2014; Hägglund 1998; Liebl 2009; O'Keeffe 1996), and nine at low risk of bias (Boullu-Sanchis 2006; Challiner 1994; Delamaire 1992; Harbo 2009; Hubble 2001; Reades 2011; Selam 1983; Slesak 2003; Spandorfer 2005).

\section{Selective reporting}

We found clinical trial registration records for two trials, both of which had been registered after the start of recruitment. For one of these trials, outcomes not mentioned in the registration record were reported within the final report so we judged this trial to be at high risk of bias (Reades 2011). There were no apparent differences in the specified outcomes for the second trial, which we judged 
to be at unclear risk of bias due to the retrospective registration (Harbo 2009). We also judged the risk of bias for the remaining 15 trials to be unclear as we had insufficient information to permit judgement.

\section{Effects of interventions}

See: Summary of findings for the main comparison Intravenous versus intraosseous route for achieving parenteral access; Summary of findings 2 Intravenous versus subcutaneous route for achieving parenteral access; Summary of findings 3 Saphenous vein cutdown versus intraosseous route for achieving parenteral access

\section{Peripheral intravenous versus intraosseus access}

We have presented separately two effect estimates from one fourperiod cross-over trial in the analyses but have not combined these with data from parallel-group trials (Lamhaut 2010 (no PPE); Lamhaut 2010 (with PPE)).

\section{Insertion failures}

Insertion failures were reported by three trials (Banerjee 1994; Lamhaut 2010 (no PPE); Lamhaut 2010 (with PPE); Reades 2011). The data from Lamhaut 2010 (no PPE) and Lamhaut 2010 (with PPE) originated from the same cross-over trial, therefore we did not pool these data in the meta-analysis. Furthermore, as there were no failures in either Lamhaut 2010 (no PPE) or Lamhaut 2010 (with PPE) treatment effects for these comparisons could not be estimated. The pooled estimate is therefore based on data from Banerjee 1994 and Reades 2011. More patients in the intravenous group experienced an insertion failure than in the intraosseous group (risk ratio (RR) $3.89,95 \%$ confidence interval $(\mathrm{Cl}) 2.39$ to 6.33; $\mathrm{n}=242 ; \mathrm{P}$ value $<0.0001$ ) (Analysis 1.1). There was moderate statistical heterogeneity between trials $\left(I^{2}=48 \%\right)$, however it was not statistically significant $\left(\mathrm{Chi}^{2} \mathrm{P}\right.$ value $\left.=0.16\right)$ and the direction of the effect estimates was consistent.

We rated the quality of the evidence as low according to GRADE, as we downgraded it for risk of bias and imprecision (Summary of findings for the main comparison).

\section{Subgroup analysis}

There was no evidence of a difference in effect according to the age of participants. The risk of insertion failure was higher in the intravenous group in both the one trial involving adults (RR 3.24, $95 \% \mathrm{Cl} 2.00$ to $5.27 ; \mathrm{n}=182 ; \mathrm{P}$ value $<0.0001$ ) (Reades 2011), and the one trial involving children (RR 21.00, 95\% $\mathrm{Cl} 1.29$ to 342.93; $\mathrm{n}=60$; $\mathrm{P}$ value $=0.03$ ) (Banerjee 1994) (test for subgroup differences: $\mathrm{Chi}^{2}$ $=1.67, \mathrm{df}=1(\mathrm{P}$ value $\left.=0.20), \mathrm{I}^{2}=40.1 \%\right)($ Analysis 1.2$)$.

\section{Time to infusion/placement}

Time to infusion/placement was reported by three trials (Banerjee 1994; Lamhaut 2010 (no PPE); Lamhaut 2010 (with PPE); Reades 2011). Due to clinical heterogeneity we did not calculate a pooled estimate, although effect estimates from each trial are presented on a forest plot to provide a visual summary. It took longer to achieve intravenous access than intraosseous access in all trials, with the difference reaching statistical significance in two trials but not in the third (Analysis 1.3).

In Reades 2011, the data for the humerus intraosseous and tibia intraosseous groups were combined for the analysis, although we note that there was a difference in the average time taken for insertion between the sites: mean \pm standard deviation (SD) for humeral insertion $=420$ seconds \pm 91.50 and for tibial insertion $=$ 276 seconds \pm 39.75 .

We rated the quality of the evidence as moderate according to GRADE, as we downgraded it for risk of bias (Summary of findings for the main comparison).

\section{Average number of insertion attempts}

The average number of insertion attempts was reported by one trial (Reades 2011). There was no difference between the two groups (mean difference (MD) $0.00,95 \% \mathrm{Cl}-0.07$ to $0.07 ; \mathrm{n}=182 ; \mathrm{P}$ value $=$ 1.00) (Analysis 1.4).

\section{Dislodgement of device during infusion}

Dislodgement of the device during infusion was reported by one trial (Reades 2011). There were fewer dislodgements in the intravenous access group, although the difference is not statistically significant (RR $0.53,95 \% \mathrm{Cl} 0.18$ to $1.55 ; \mathrm{n}=182$; $\mathrm{P}$ value $=0.25$ ) (Analysis 1.5). Most of the dislodgements (10/13) occurred in the intraosseous patients who had the device inserted into the proximal humerus.

We rated the quality of the evidence as low according to GRADE, as we downgraded it for risk of bias and imprecision (Summary of findings for the main comparison).

\section{Time with functional access}

None of the trials reported data on this outcome.

\section{Local site reactions}

\section{Infection}

One trial, involving the infusion of bone marrow, reported number of patients who developed bacteraemia during the first month (Hägglund 1998). There were fewer cases of bacteraemia in the intravenous group, although the difference was not statistically significant (RR 5.57, 95\% Cl 0.35 to $88.77 ; n=28 ; \mathrm{P}$ value $=0.22$ ) (Analysis 1.6).

\section{Clinician's perception of administration of access route}

One trial measured the paramedics' perception of how comfortable they felt when administering each method to each patient (Reades 2011). Paramedics were less likely to report that they were uncomfortable when inserting via the intravenous route (RR 0.15 , $95 \% \mathrm{Cl} 0.04$ to $0.61 ; \mathrm{n}=182 ; \mathrm{P}$ value $=0.008)$ (Analysis 1.7) .

\section{Needlestick injuries}

None of the trials reported data on this outcome.

\section{Patient discomfort}

None of the trials reported data on this outcome.

\section{Mortality}

None of the trials reported data on this outcome.

\section{Volume of fluid infused}

The volume of fluid infused was reported by one trial (Reades 2011). A larger volume of fluid was infused via the intravenous route than 
the intraosseous route (MD $400 \mathrm{ml}, 95 \% \mathrm{Cl} 365.57$ to $434.43 ; \mathrm{n}=182$ $P$ value $<0.0001$ ) (Analysis 1.8)

We rated the quality of the evidence as moderate according to GRADE, as we downgraded it for risk of bias (Summary of findings for the main comparison).

\section{Electrolyte level}

Electrolyte level was reported by one trial (Banerjee 1994). There was no evidence of a difference in serum sodium (MD $-1.00,95 \% \mathrm{Cl}$ -5.36 to $3.36 ; n=60 ; P$ value $=0.65)$ or potassium $(M D-0.40,95 \% \mathrm{Cl}$ -2.97 to $2.17 ; \mathrm{n}=60 ; \mathrm{P}$ value $=0.76$ ) between groups (Analysis 1.9).

\section{Renal function}

Renal function was reported by one trial (Banerjee 1994). The average levels of both urea and creatinine were lower in the intravenous group; the difference was not statistically significant for urea (MD $-5.00,95 \% \mathrm{Cl}-10.53$ to $0.53 ; n=60 ; P$ value $=0.08)$, but it was statistically significant for creatinine (MD $-35.00,95 \% \mathrm{Cl}-44.66$ to $-25.34 ; n=60 ; P$ value $<0.0001$ ) (Analysis 1.10)

\section{Sensitivity analysis}

Sensitivity analysis was not possible as we judged none of the trials comparing intravenous and intraosseous access to be at low risk of bias for allocation concealment.

\section{Peripheral intravenous versus subcutaneous access}

\section{Insertion failures}

Insertion failures were reported by three trials (Delamaire 1992; O'Keeffe 1996; Spandorfer 2005). More patients in the intravenous group experienced an insertion failure than in the subcutaneous group (RR $14.79,95 \% \mathrm{Cl} 2.87$ to $76.08 ; \mathrm{n}=238$ ) (Analysis 2.1). There was no statistical heterogeneity between trials $\left(\mathrm{Chi}^{2} \mathrm{P}\right.$ value $=0.50$; $\left.1^{2}=0 \%\right)$.

We rated the quality of the evidence as moderate according to the GRADE system, as we downgraded it for imprecision (Summary of findings 2).

\section{Sensitivity analysis}

The effect remained when we restricted the analysis to the one trial with adequate allocation concealment (Spandorfer 2005) (RR $32.13,95 \% \mathrm{Cl} 1.96$ to $525.87 ; \mathrm{n}=148 ; \mathrm{P}$ value $=0.01$ ) (Analysis 2.2).

\section{Subgroup analysis}

Two trials involved adults (Delamaire 1992; O'Keeffe 1996), and one trial involved children (Spandorfer 2005). The effect estimates for both subgroups were consistent, with an increased risk of insertion failures in the intravenous group, although the effect was not statistically significant for the subgroup of trials involving adults (adults RR 6.00, 95\% $\mathrm{Cl} 0.76$ to 47.39; $\mathrm{n}=90 ; \mathrm{P}$ value $=0.09$ versus children RR $32.13,95 \% \mathrm{Cl} 1.96$ to $525.87 ; \mathrm{n}=148$; $\mathrm{P}$ value $=0.01$ ). However, there is no evidence that the effect varied between these subgroups (test for subgroup differences: $\mathrm{Chi}^{2}=0.90, \mathrm{df}=1$ ( $\mathrm{P}$ value $\left.=0.34), \mathrm{I}^{2}=0 \%\right)$.

\section{Time to infusion/placement}

Time to placement/start of infusion was reported by two trials (Slesak 2003; Spandorfer 2005). Insertion of the intravenous route took longer than the subcutaneous route in both trials, however a pooled estimate could not be calculated because of insufficient data (i.e. no variance estimates) presented in Spandorfer 2005.

In Slesak 2003, it took on average two minutes longer (MD 120.00 seconds, $95 \% \mathrm{Cl}-4.80$ to $244.80 ; n=96 ; P$ value $=0.06$ ) to insert via the intravenous route (Analysis 2.4). In Spandorfer $2005(n=148)$, the median time from first insertion attempt to start of infusion in the intravenous group was 11.8 minutes compared to 3.5 minutes in the subcutaneous group.

We rated the quality of the evidence as low according to GRADE, as we downgraded it for risk of bias and imprecision (Summary of findings 2).

\section{Average number of insertion attempts}

The average number of insertion attempts was not directly measured by any of the trials. However, O'Keeffe $1996(n=60)$ reported that 41 cannulae were used in the intravenous group compared to 34 in the subcutaneous group.

\section{Dislodgement of device during infusion}

One trial reported the number of dislodgements caused by patients pulling out the device (Duems Noriega 2014). Patients in the intravenous group were more likely to dislodge the device than those in the subcutaneous group (RR $3.78,95 \% \mathrm{Cl} 1.16$ to $12.34 ; \mathrm{n}=$ $67 ; P$ value $=0.03)($ Analysis 2.5) .

We rated the quality of the evidence as low according to GRADE, as we downgraded it for risk of bias and imprecision (Summary of findings 2).

\section{Time with functional access}

One trial measured the length of time in days before each cannula needed to be changed (Slesak 2003). There was no statistically significant difference observed between groups (MD 0.80 days, $95 \%$ $\mathrm{Cl}-0.05$ to $1.65 ; \mathrm{n}=96 ; \mathrm{P}$ value $=0.07$ ) (Analysis 2.6)

\section{Local site reactions}

See Analysis 2.7 and Analysis 2.8 .

Any

The occurence of any local site reactions was reported by five trials (Boullu-Sanchis 2006; Challiner 1994; Harbo 2009; Selam 1983; Spandorfer 2005). There were fewer local site reactions in the intravenous group than in the subcutaneous group, although the difference was not statistically significant (RR 0.91, 95\% Cl 0.80 to $1.02 ; n=247$ ). There was substantial statistical heterogeneity between trials $\left(\mathrm{Chi}^{2} \mathrm{P}\right.$ value $\left.<0.0001 ; \mathrm{I}^{2}=58 \%\right)$.

\section{Sensitivity analysis}

There was a statistically significant reduced risk associated with the intravenous method when the analysis was restricted to the three trials with adequate allocation concealment (Challiner 1994; Harbo 2009; Spandorfer 2005) (RR 0.87, $95 \% \mathrm{Cl} 0.79$ to $0.96 ; n=202)$. There was no evidence of statistical heterogeneity between trials $\left(\mathrm{Chi}^{2} \mathrm{P}\right.$ value $=0.30 ; I^{2}=17 \%$ )

\section{Erythema}

Erythema was reported by four trials (Challiner 1994; Harbo 2009; Slesak 2003; Spandorfer 2005). There were fewer cases of erythema 
in the intravenous group than in the subcutaneous group (RR 0.43, $95 \% \mathrm{Cl} 0.31$ to $0.61 ; \mathrm{n}=296)$. There was substantial statistical heterogeneity between trials $\left(\mathrm{Chi}^{2} \mathrm{P}\right.$ value $<0.0001 ; \mathrm{I}^{2}=63 \%$ ).

\section{Sensitivity analysis}

The effect remained when we restricted the analysis to the three trials with adequate allocation concealment (Challiner 1994; Harbo 2009; Spandorfer 2005) (RR 0.33, 95\% Cl 0.22 to $0.49 ; n=202$ ). There was no statistical heterogeneity between trials $\left(\mathrm{Chi}^{2} \mathrm{P}\right.$ value $=0.73$; $\left.\mathrm{I}^{2}=0 \%\right)$

\section{Swelling}

Swelling was reported by one trial (Spandorfer 2005). There were fewer cases of swelling in the intravenous group than in the subcutaneous group (RR $0.26,95 \% \mathrm{Cl} 0.17$ to $0.41 ; \mathrm{n}=148$ ).

\section{Infection}

Infection was reported by four trials (Delamaire 1992; Duems Noriega 2014; Harbo 2009; Slesak 2003). More patients in the intravenous group developed an infection (e.g. cellulitis and lymphangitis) compared to the subcutaneous group (RR 3.70, 95\% $\mathrm{Cl} 1.06$ to $12.88 ; \mathrm{n}=211 ; \mathrm{P}$ value $=0.04)$. There was no statistical heterogeneity between trials $\left(\mathrm{Chi}^{2} \mathrm{P}\right.$ value $=0.37 ; \mathrm{I}^{2}=6 \%$ ).

\section{Sensitivity analysis}

There was no difference in the risk of infection between groups when we restricted the analysis to the one trial with adequate allocation concealment (Harbo 2009) (RR 3.00, 95\% Cl 0.14 to 65.16; $\mathrm{n}=18 ; \mathrm{P}$ value $=0.48)$.

\section{Oedema}

Oedema was reported by seven trials (Challiner 1994; Delamaire 1992; Duems Noriega 2014; Harbo 2009; O'Keeffe 1996; Slesak 2003; Spandorfer 2005). Fewer patients in the intravenous group experienced oedema at the insertion site compared to those in the subcutaneous group (RR $0.42,95 \% \mathrm{Cl} 0.25$ to $0.72 ; n=453$; $P$ value $=0.001)$. There was no statistical heterogeneity between trials $\left(\mathrm{Chi}^{2}\right.$ $P$ value $=0.89 ; I^{2}=0 \%$.

\section{Sensitivity analysis}

The effect was not statistically significant when we restricted the analysis to the three trials with adequate allocation concealment (Challiner 1994; Harbo 2009; Spandorfer 2005) (RR 0.25, 95\% Cl 0.06 to $1.15 ; \mathrm{n}=202 ; \mathrm{P}$ value $=0.07)$. There was no statistical heterogeneity between trials $\left(\mathrm{Chi}^{2} \mathrm{P}\right.$ value $\left.=0.93 ; \mathrm{I}^{2}=0 \%\right)$.

\section{Phlebitis}

Phlebitis was reported by three trials (Duems Noriega 2014; Harbo 2009; Slesak 2003). More patients in the intravenous group experienced phlebitis than in the subcutaneous group (RR 5.04, $95 \% \mathrm{Cl} 1.14$ to $22.30 ; n=181)$. There was no statistical heterogeneity between trials $\left(\mathrm{Chi}^{2} \mathrm{P}\right.$ value $\left.=0.93 ; \mathrm{I}^{2}=0 \%\right)$.

\section{Sensitivity analysis}

The effect was not statistically significant when we restricted the analysis to the one trial with adequate allocation concealment (Harbo 2009) (RR 3.00, 95\% Cl 0.14 to 65.16; $\mathrm{n}=18$; $\mathrm{P}$ value $=0.48$ ).

\section{Clinician's perception of ease of administration}

Slesak 2003 measured doctors' and nurses' perceptions of the feasibility of each insertion method using a Likert-like scale. There was no difference between the perceived feasibility of the two methods when scored by either the nurses (MD 0.00, 95\% Cl - 0.12 to $0.12 ; \mathrm{n}=87 ; \mathrm{P}$ value $=1.00$ ) or doctors $(\mathrm{MD} 0.00,95 \% \mathrm{Cl}-0.14$ to $0.14 ; \mathrm{n}=96 ; \mathrm{P}$ value $=1.00$ ) (Analysis 2.9)

In Spandorfer 2005, clinicians were more likely to report that the intravenous access was difficult to perform than the subcutaneous access (RR 6.33, 95\% Cl 2.32 to 17.23; $\mathrm{n}=148 ; \mathrm{P}$ value $=0.0003$ ) (Analysis 2.10).

\section{Needlestick injuries}

None of the trials reported data on this outcome.

\section{Patient discomfort}

\section{Pain}

Three trials reported the number of patients with pain associated with the parenteral access method (Harbo 2009; Slesak 2003; Spandorfer 2005). There is no evidence that the number of patients reporting pain differed between the intravenous and subcutaneous groups ( $\mathrm{RR} 1.01,95 \% \mathrm{Cl} 0.83$ to $1.22 ; \mathrm{n}=262$; $\mathrm{P}$ value $=0.94$ ). There was no statistical heterogeneity between trials $\left(\mathrm{Chi}^{2} \mathrm{P}\right.$ value $=0.33$; $1^{2}=9 \%$ ) (Analysis 2.11). We downgraded the quality of the evidence to low, due to high risk of bias and imprecision arising from small sample sizes.

\section{Sensitivity analysis}

The lack of evidence for a difference remained when we restricted the analysis to the two trials with adequate allocation concealment (Harbo 2009; Spandorfer 2005) (RR 0.97, 95\% Cl 0.81 to 1.16 ; $n=$ $166 ; \mathrm{P}$ value $=0.77)$. There was evidence of statistical heterogeneity between trials $\left(I^{2}=53 \%\right)$; however, it was not statistically significant $\left(\mathrm{Chi}^{2} \mathrm{P}\right.$ value $\left.=0.15\right)$ (Analysis 2.12).

\section{Discomfort}

In Slesak 2003, patients were also asked to score the discomfort of the procedure ( $1=$ very good to $6=$ very bad). There was no difference in the patients' scores between the two groups (MD 0.00, $95 \% \mathrm{Cl}-0.21$ to $0.21 ; \mathrm{n}=54 ; \mathrm{P}$ value $=1.00$ ) (Analysis 2.13)

\section{Agitation}

Two trials reported the number of patients who were agitated (Duems Noriega 2014; O'Keeffe 1996). Patients in the intravenous group were more likely to be agitated than those in the subcutaneous group (RR $1.84,95 \% \mathrm{Cl} 1.26$ to $2.70 ; n=125$; $P$ value $=0.002)$. There was no statistical heterogeneity between trials $\left(\mathrm{Chi}^{2}\right.$ $P$ value $\left.=0.34 ; I^{2}=0 \%\right)$.

\section{Mortality}

Mortality was reported by two trials (Challiner 1994; Duems Noriega 2014). In Challiner 1994, one patient in the subcutaneous group died on day two and in Duems Noriega 2014, three patients (two in the intravenous group, one in the subcutaneous group) died in the first 72 hours. When we pooled the data there was no difference in the risk of death between groups (RR $1.04,95 \% \mathrm{Cl} 0.18$ to $5.92 ; \mathrm{n}=$ $103 ; P$ value $=0.96$ ). There was no statistical heterogeneity between trials $\left(\mathrm{Chi}^{2} \mathrm{P}\right.$ value $=0.40 ; \mathrm{I}^{2}=0 \%$ ) (Analysis 2.14 ) 


\section{Sensitivity analysis}

The lack of evidence for a difference in risk remained when we restricted the analysis to the one trial with adequate allocation concealment (Challiner 1994) (RR 0.37, 95\% Cl 0.02 to $8.53 ; \mathrm{n}=36$; $P$ value $=0.53)($ Analysis 2.15)

\section{Volume of fluid infused}

The volume of fluid infused was reported by four trials (Duems Noriega 2014; O'Keeffe 1996; Slesak 2003; Spandorfer 2005). Due to clinical heterogeneity we did not calculate a pooled estimate, although effect estimates from each trial are presented on a forest plot to provide a visual summary (Analysis 2.16). A larger volume of fluid was infused via the intravenous route in all but one trial.

We rated the quality of the evidence as low according to GRADE, as we downgraded it for risk of bias and inconsistency (Summary of findings 2).

\section{Sensitivity analysis}

There was no difference in the volume of fluid infused in the one trial with adequate allocation concealment (Spandorfer 2005) (MD $90.8095 \% \mathrm{Cl}-63.55$ to $245.15 ; \mathrm{n}=148$; $\mathrm{P}$ value $=0.25$ )

\section{Electrolyte levels}

\section{Sodium}

Sodium level was reported by one trial (Slesak 2003). The mean sodium level was higher in the intravenous group (139 $\pm 5 \mathrm{mmol} /$ l) compared to the subcutaneous group (137 $\pm 5 \mathrm{mmol} / \mathrm{l})$, although the difference is not statistically significant (MD -2.00 mmol/l, 95\% -0.24 to $4.24 ; \mathrm{n}=77 ; \mathrm{P}$ value $=0.08$ ) (Analysis 2.18 )

\section{Potassium}

None of the trials reported data on this outcome.

\section{Renal function}

See Analysis 2.19.

\section{Urea}

Urea level was reported by one trial (Duems Noriega 2014). Urea levels were on average lower in the intravenous group than in the subcutaneous group, although the difference is not statistically significant (MD $-11.29 \mathrm{mg} / \mathrm{dL}, 95 \% \mathrm{Cl}-24.69$ to $2.11 ; \mathrm{n}=67$; $\mathrm{P}$ value $=0.10)$.

\section{Creatinine}

Creatinine level was reported by two trials (Duems Noriega 2014; Slesak 2003). There was no difference in creatinine levels between the two groups $(\mathrm{MD}-0.08,95 \% \mathrm{Cl}-0.33$ to $0.16 ; \mathrm{n}=138 ; \mathrm{P}$ value $=$ 0.51). There was no statistical heterogeneity between trials $\left(\mathrm{Chi}^{2} \mathrm{P}\right.$ value $\left.=0.95 ;\left.\right|^{2}=0 \%\right)$

\section{Saphenous vein cutdown versus intraosseous access}

This comparison was assessed by one cross-over trial $(n=13)$ (Hubble 2001).

\section{Insertion failures}

There were more failures when attempting saphenous vein cutdown than intraosseous access, although the difference was not statistically significant (RR 4.00, 95\% $\mathrm{Cl} 0.51$ to 31.13 ; $\mathrm{P}$ value $=0.19)$ (Analysis 3.1).

We rated the quality of the evidence as low according to GRADE, as we downgraded it for risk of bias and imprecision (Summary of findings 3$)$.

\section{Time to infusion/placement}

On average it took about 3.5 minutes longer to achieve access by saphenous vein cutdown than intraosseous access (MD 219.60 seconds, $95 \% \mathrm{Cl} 135.44$ to 303.76 ; $\mathrm{P}$ value < 0.0001 ) (Analysis 3.2).

We rated the quality of the evidence as moderate according to GRADE, as we downgraded it for risk of bias (Summary of findings $3)$.

\section{Average number of insertion attempts}

The trial did not report data on this outcome.

\section{Dislodgement of device during infusion}

The trial did not report data on this outcome.

\section{Time with functional access}

This outcome was not relevant, as insertion attempts were on a cadaver.

\section{Local site reactions}

This outcome was not relevant, as both insertion attempts were on a cadaver.

\section{Clinician's perception of ease/feasibility of access route}

The trial did not report data on this outcome.

\section{Needlestick injuries}

The trial did not report data on this outcome.

\section{Patient discomfort}

This outcome was not relevant, as insertion attempts were on a cadaver.

\section{Mortality}

This outcome was not relevant, as insertion attempts were on a cadaver.

\section{Volume of fluid infused}

This outcome was not relevant, as insertion attempts were on a cadaver.

\section{Electrolyte levels}

This outcome was not relevant, as insertion attempts were on a cadaver.

\section{Renal function}

This outcome was not relevant, as insertion attempts were on a cadaver. 


\section{Peripheral intravenous versus intraperitoneal access}

This comparison was assessed by one cross-over trial $(n=6)$ (Selam 1983), which compared intravenous and intraperitoneal access for insulin infusion.

\section{Insertion failures}

The trial did not report data on this outcome.

\section{Time to infusion/placement}

The trial did not report data on this outcome.

\section{Average number of insertion attempts}

The trial did not report data on this outcome.

\section{Dislodgement of device during infusion}

The trial did not report data on this outcome.

\section{Time with functional access}

The trial did not report data on this outcome.

\section{Local site reactions}

One of the six patients suffered an obstructed catheter during the intravenous phase. No complications data were reported for the intraperitoneal group.

\section{Clinician's perception of ease of administration}

The trial did not report data on this outcome.

\section{Needlestick injuries}

The trial did not report data on this outcome.

\section{Patient discomfort}

Two of six patients suffered transient episodes of abdominal pain during the intraperitoneal phase. No pain data were reported for the intravenous group.

\section{Mortality}

The trial did not report data on this outcome.

\section{Volume of fluid infused}

This outcome was not relevant, as both trials involved the infusion of medication, not fluids for hydration.

\section{Electrolyte levels}

This outcome was not relevant, as both trials involved the infusion of medication, not fluids for hydration.

\section{Renal function}

This outcome was not relevant, as both trials involved the infusion of medication, not fluids for hydration.

\section{Intraperitoneal versus subcutaneous access}

Two cross-over trials compared the intraperitoneal and subcutaneous routes for infusion of medications (Liebl 2009; Selam 1983).

\section{Insertion failures}

The trials did not report data on this outcome.

\section{Time to infusion/placement}

The trials did not report data on this outcome.

\section{Average number of insertion attempts}

The trials did not report data on this outcome.

\section{Dislodgement of device during infusion}

The trials did not report data on this outcome.

\section{Time with functional access}

The trials did not report data on this outcome.

\section{Local site reactions}

In Selam 1983, all six patients experienced local reactions after three to four weeks of the subcutaneous phase, beginning with induration and inflammation at the insertion site before rejection of the catheter.

In Liebl 2009, it is reported that $21 \%$ of patients in months one to six and $10 \%$ patients in months seven to 12 experienced local inflammation or infection during the intraperitoneal phase. The number of complications during the subcutaneous phase was not reported.

\section{Clinician's perception of ease of administration}

The trials did not report data on this outcome.

\section{Needlestick injuries}

The trials did not report data on this outcome.

\section{Patient discomfort}

In Selam 1983, two of the six patients suffered transient episodes of abdominal pain during the intraperitoneal phase.

In Liebl 2009, it is reported that $12 \%$ of patients in months one to six and $49 \%$ in months seven to 12 reported severe pain during the intraperitoneal phase.

\section{Mortality}

The trials did not report data on this outcome.

\section{Volume of fluid infused}

This outcome was not relevant, as both trials involved the infusion of medication not fluids for hydration.

\section{Electrolyte levels}

This outcome was not relevant, as both trials involved the infusion of medication not fluids for hydration.

\section{Renal function}

This outcome was not relevant, as both trials involved the infusion of medication not fluids for hydration. 


\section{Reporting bias}

There were insufficient data to produce funnel plots for any of the outcomes.

\section{DISCUSSION}

\section{Summary of main results}

Evidence from randomised controlled trials suggests that intraosseous access may be achieved more rapidly and with fewer insertion failures than intravenous access. Subcutaneous access is also associated with fewer insertion failures than intravenous access. Taken together the evidence suggests that intraosseous and subcutaneous access are viable alternatives to peripheral intravenous access when the latter cannot be achieved. However, when inserted successfully, more fluid can be infused by the intravenous route than by either the intraosseous or subcutaneous route.

Only one small trial involving insertion of parenteral access into manikins explored the effect of personal protective equipment (PPE), thus there is insufficient evidence to determine reliably whether or not the use of PPE impacts on the merits of the different approaches. Also, there is insufficient evidence to draw any inferences about the relative merits of intraperitoneal access compared to other methods and there are no trials involving central intravenous access.

A particularly important consideration in the context of patients with Ebola virus disease (EVD) may be the likelihood of dislodgement of the parenteral access device during use. Two trials, one comparing intravenous with intraosseous access and one comparing intravenous with subcutaneous access, recorded the number of dislodgements. However, both were inadequately powered and were at risk of bias for important quality domains. They therefore do not provide reliable evidence on this important outcome so we are unable to draw any firm conclusions. There are also insufficient data to determine whether the intravenous route is associated with an increased or decreased risk of adverse events when compared to intraosseous access. When compared to subcutaneous access, intravenous access appears to cause less erythema, but more infection and phlebitis. However, the difference between the two methods in the risk of infection and phlebitis was not statistically significant when we restricted these analyses to trials with adequate allocation concealment. As expected given the nature of the insertion, subcutaneous infusion was associated with an increased risk of oedema and swelling.

\section{Overall completeness and applicability of evidence}

The included trials were conducted in a variety of clinical contexts involving a broad range of patient groups. Despite this we judged them to be sufficiently clinically homogenous to allow pooled analyses for most outcomes. As we anticipated at the protocol stage, none of the included trials were conducted in the context of EVD or a similar medical emergency. However, we judge that the advantages and disadvantages of the different parenteral methods observed in other clinical settings are likely to be similar in the context of EVD. If a trial, or a meta-analysis of all relevant trials, shows that a particular intervention increases or decreases the probability of a given outcome in one group of patients, we have to consider what effect it might have in another group of patients. Some people believe that an intervention should only be used in patients similar to those included in the trial (or trials) that showed the intervention to be effective. We believe that this view is naive. To generalise trial results properly we have to consider the mechanism by which the intervention affected the outcome and the factors that might be relevant to this mechanism. The results of this systematic review suggest that insertion of intraosseous access may be less likely to fail and may be quicker than the intravenous method. Would this also be the case in patients with EVD? Patients with EVD are often severely dehydrated due to severe gastrointestinal fluid losses. In such patients, we might reasonably expect that securing intravenous access would be even more difficult. Healthcare workers treating patients with EVD must wear personal protective equipment and often wear two or even three layered pairs of protective gloves. This would be expected to reduce their ability to palpate a vein, which would again make securing intravenous access more difficult. On the other hand, dehydration and health worker dexterity are less important for intraosseous access. For this reason, we would expect that securing intraosseous access would usually be quicker and easier than securing intravenous access in patients with EVD.

\section{Quality of the evidence}

We judged few trials to be at low risk of bias for any of the assessed domains. Of particular concern is the small number of trials $(n=$ 3) that used adequate allocation concealment. Where possible we explored the influence of trials with unclear or high risk of bias for allocation concealment using sensitivity analyses. Blinding was not feasible due to the nature of the interventions and this may have introduced bias, particularly in the assessment of subjective outcomes. In some trials, attrition between groups might also have introduced bias. For example, in Banerjee 199410 patients $(30 \%)$ allocated to the intravenous group were switched to the intraosseous group because venous access could not be achieved. It is possible that these patients were more dehydrated, which might account for the difficulty with venous access. As the trial data were not presented on an intention-to-treat basis, a favourable effect of intraosseous access on outcomes may have been diluted.

Also, because the estimated information size for the meta-analysis $(n=1388$ ) was not achieved for the primary outcome (insertion failures) for any of the routes compared, we cannot discount the possibility that the observed increase in risk of insertion failure associated with the intravenous method compared to both the intraosseous and subcutaneous methods are false positives, although the $P$ values accompanying the pooled effect estimates are very small $(\leq 0.001)$.

\section{Potential biases in the review process}

As with all systematic reviews, publication and reporting biases should be considered as potential threats to the validity of the findings of this review. We undertook comprehensive searching but cannot discount the possibility that trials, in particular unpublished trials, were not identified.

Also, few trials contributed data to each outcome, which may suggest some selective outcome reporting. Indeed, comparison of prespecified outcomes with those given in the final report for the one trial that was prospectively registered, did suggest selective outcome reporting. However, this could not be explored for the other included trials, which had not been prospectively registered. We were also unable to explore the presence of reporting bias using 
funnel plots because there were too few trials included in the metaanalyses.

Two trials reported data for some continuous outcomes as medians and ranges (Reades 2011; Slesak 2003). To allow these data to be included in the meta-analyses, we estimated the corresponding means and standard deviations using the approach described in Hozo 2005. However, meta-analysis of the difference in means is appropriate, assuming that the data are normally distributed. That these data were presented as medians and ranges may indicate that their distributions were skewed and not normally distributed. The estimates of the mean difference based on these data should therefore be interpreted with caution.

\section{Agreements and disagreements with other studies or reviews}

The findings of this systematic review are largely consistent with those of other relevant literature reviews. We identified two other reviews that summarised the results of observational and intervention studies assessing the use of subcutaneous infusion for treating dehydration in older adults (Remington 2007; Rochon 1997). The conclusion of both reviews was that subcutaneous infusion is a safe and feasible alternative to intravenous fluid administration for treating mild to moderate dehydration in the elderly.

Another article reported the results of a systematic review of observational and intervention studies assessing the effectiveness of non-oral and non-intravenous methods for treating dehydration in children (Rouhani 2011). The authors noted the lack and limited quality of the evidence, but concluded that the intraosseous method could be an effective alternative when intravenous access is not feasible. Although they noted promising results from case series studies, they also concluded that there was insufficient evidence to recommend the intraperitoneal or subcutaneous method above other parenteral access methods in this patient group.

\section{AUTHORS' CONCLUSIONS}

\section{Implications for practice}

There are several different ways of achieving parenteral access in patients who are unable to meet their fluid requirements enterally. In view of the large number of cases and the severe resource constraints, methods for achieving parenteral access in the context of Ebola virus disease (EVD) need to be simple, easy and quick, and must not put healthcare workers at unnecessary risk. The quality of the evidence in this review is somewhat limited, largely because of the lack of adequately powered trials at low risk of bias. Although this prevents us from drawing firm conclusions regarding the magnitude of the difference between parenteral access methods, useful inferences about the likely direction of effects can be made for some outcomes.

The choice of method used in clinical practice may depend on sitespecific issues such as the availability and expertise of medical and nursing staff, patient numbers and local infrastructure. If intravenous access can be achieved easily, this facilitates the infusion of larger volumes of fluid and also allows blood samples to be drawn for testing (e.g. for EVD or malaria) at the time of insertion. However, if this is not possible, intraosseous and subcutaneous routes are alternatives that can be achieved rapidly. The subcutaneous route may be suitable for patients who are not severely dehydrated but in whom ongoing fluid losses cannot be met by oral intake. Given the ease of insertion of subcutaneous lines, they could be inserted by healthcare workers with minimal medical training.

It is expected that most clinicians are familiar with the intravenous method, but may be less so with the other methods although these can be easily taught.

A film to accompany this review can be viewed here.

\section{Implications for research}

The quality of the included trials was low. Further comparative trials of alternative approaches are appropriate if those caring for patients with EVD remain uncertain about which is the most effective strategy for securing reliable parenteral access. Importantly, there is no reliable information on the extent to which the different parenteral access devices are dislodged during use. This might be particularly relevant in the context of the current epidemic of EVD, where there are shortages of nursing and medical staff, since the volume of fluid administered might depend on the duration of parenteral access. Also, there is a lack of data on the impact of personal protective equipment on parenteral access methods and whether effects differ in children, which should be addressed by future trials. There are no data on the relative merits of intraperitoneal access. This method has been used to resuscitate severely dehydrated infants with cholera in whom achieving intravenous access is difficult (Mahalanabis 1970). Whether it is more effective than intravenous, intraosseous or subcutaneous access remains unknown. Future trials should be prospectively registered, have secure allocation concealment, adequate sample sizes and should be reported according to established standards.

\section{ACKN OWLEDGEMENTS}

We are grateful for feedback from the anonymous peer referees. We acknowledge the support and assistance from the Cochrane Editorial Unit, especially Toby Lasserson. We also thank Monica Arribas and Emma Sydenham for help with the translation of nonEnglish language articles.

This project was supported by the National Institute for Health Research, UK, through Cochrane Infrastructure funding to the Cochrane Injuries Group. The views and opinions expressed are those of the authors and do not necessarily reflect those of the Systematic Reviews Programme, NIHR, NHS or the Department of Health. 


\section{RE F E R E N C E S}

\section{References to studies included in this review}

\section{Banerjee 1994 \{published data only\}}

Banerjee S, Singhi S, Singh SC, Singh M. The intraosseous route is a suitable alternative to intravenous route for fluid resuscitation in severely dehydrated children. Indian Pediatrics 1994;31(12):1511-20.

\section{Boullu-Sanchis 2006 \{published data only\}}

Boullu-Sanchis S, Ortega F, Chabrier G, Busch MS, Uhl C, Pinget $\mathrm{M}$, et al. Efficacy of short term continuous subcutaneous insulin lispro versus continuous intravenous regular insulin in poorly controlled, hospitalized, type 2 diabetic patients. Diabetes \& Metabolism 2006;32(4):350-7.

\section{Challiner 1994 \{published data only\}}

Challiner YC, Jarrett D, Hayward MJ, al-Jubouri MA, Julious SA. A comparison of intravenous and subcutaneous hydration in elderly acute stroke patients. Postgraduate Medical Journal 70;821:195-7.

\section{Dardaine 1995 \{published data only\}}

Dardaine V, Garrigue MA, Rapin CH, Constans T. Metabolic and hormonal changes induced by hypodermoclysis of glucose-saline solution in elderly patients. Journals of Gerontology Series A-Biological Sciences \& Medical Sciences 1995;50(6):M334-6.

\section{Delamaire 1992 \{published data only\}}

Delamaire D, Meigne B, Lecoq A, Cattenoz C, Michel M, Miche O. A rehydration randomized trial favoring the subcutaneous route in the elderly [Un essai controle d'hydratation en faveur d'une actualisation de l'hypodermoclyse chez le sujet age]. Revue de Medecine Interne 1992;13(7):S321.

\section{Duems Noriega 2014 \{published data only\}}

Duems Noriega O, Arino Blasco S. Efficacy of the subcutaneous route compared to intravenous hydration in the elderly hospitalised patient: a randomised controlled study. Revista Espanola de Geriatria y Gerontologia 2014;49(3):103-7.

\section{Hägglund 1998 \{published data only\}}

Hägglund H, Ringdén O, Agren B, Wennberg L, Remberger M, Rundquist $L$, et al. Intraosseous compared to intravenous infusion of allogeneic bone marrow. Bone Marrow Transplantation 1998;21(4):331-5.

\section{Harbo 2009 \{published data only\}}

Harbo T, Andersen H, Hess A, Hansen K, Sindrup SH, Jakobsen J. Subcutaneous versus intravenous immunoglobulin in multifocal motor neuropathy: a randomized, singleblinded cross-over trial. European Journal of Neurology 2009;16(5):631-8.

\section{Harvey 1987 \{published data only\}}

Harvey VJ, Slevin ML, Aherne GW, Littleton P, Johnston A, Wrigley PF. Subcutaneous infusion of bleomycin--a practical alternative to intravenous infusion. Journal of Clinical Oncology 1987;5(4):648-50.
Hubble 2001 \{published data only\}

Hubble MW, Trigg DC. Training prehospital personnel in saphenous vein cutdown and adult intraosseous access techniques. Prehospital Emergency Care 2001;5(2):181-9.

Lamhaut 2010 (no PPE) \{published data only\}

Lamhaut L, Dagron C, Apriotesei R, Gouvernaire J, Elie C, Marx JS, et al. Comparison of intravenous and intraosseous access by pre-hospital medical emergency personnel with and without CBRN protective equipment. Resuscitation 2010;81(1):65-8.

Lamhaut 2010 (with PPE) \{published data only\} Lamhaut L, Dagron C, Apriotesei R, Gouvernaire J, Elie C, Marx JS, et al. Comparison of intravenous and intraosseous access by pre-hospital medical emergency personnel with and without CBRN protective equipment. Resuscitation 2010;81(1):65-8.

\section{Liebl 2009 \{published data only\}}

Liebl A, Hoogma R, Renard E, Geelhoed-Duijvestijn PH, Klein E, Diglas $\mathrm{J}$, et al. A reduction in severe hypoglycaemia in type 1 diabetes in a randomized crossover study of continuous intraperitoneal compared with subcutaneous insulin infusion. Diabetes, Obesity \& Metabolism 2009;11(11):1001-8.

O'Keeffe 1996 \{published data only\}

O'Keeffe ST, Lavan JN. Subcutaneous fluids in elderly hospital patients with cognitive impairment. Gerontology 1996;42(1):36-9.

\section{Reades 2011 \{published data only\}}

Reades R, Studnek JR, Vandeventer S, Garrett J. Intraosseous versus intravenous vascular access during out-of-hospital cardiac arrest: a randomized controlled trial. Annals of Emergency Medicine 2011;58(6):509-16.

\section{Selam 1983 \{published data only\}}

Selam JL, Slingeneyer A, Hedon B, Mares P, Beraud JJ, Mirouze J. Long-term ambulatory peritoneal insulin infusion of brittle diabetes with portable pumps: comparison with intravenous and subcutaneous routes. Diabetes Care 1983;6(2):105-11.

\section{Slesak 2003 \{published data only\}}

Slesak G, Schnurle JW, Kinzel E, Jakob J, Dietz PK. Comparison of subcutaneous and intravenous rehydration in geriatric patients: a randomized trial. Journal of the American Geriatrics Society 2003;51(2):155-60.

\section{Spandorfer 2005 \{published data only\}}

Spandorfer PR, Alessandrini EA, Joffe MD, Localio R, Shaw KN. Oral versus intravenous rehydration of moderately dehydrated children: a randomized, controlled trial. Pediatrics 2005;115:295-301. 


\section{References to studies excluded from this review}

\section{Chavez-Negrete 1991 \{published data only\}}

Chavez-Negrete A, Majluf Cruz S, Frati Munari A, Perches A, Arguero R. Treatment of hemorrhagic shock with intraosseus or intravenous infusion of hypertonic saline dextran solution. European Surgical Research 1991;23(2):123-9.

\section{Ismael 2012 \{published data only\}}

Ismael G, Hegg R, Muehlbauer S, Heinzmann D, Lum B, Kim S, et al. Subcutaneous versus intravenous administration of (neo)adjuvant trastuzumab in patients with HER2-positive, clinical stage I-III breast cancer (HannaH study): a phase 3, open-label, multicentre, randomised trial. Lancet Oncology 2012;13(9):869-78.

\section{Klemenz 1997 \{published data only\}}

Klemenz BE. Subcutaneous versus intravenous rehydration therapy in older patients. Deutsche Medizinische Wochenschrift 1997;122(49):1540-1.

\section{Koshy 2005 \{published data only\}}

Koshy RC, Kuriakose R, Sebastian P, Koshy C. Continuous morphine infusions for cancer pain in resource-scarce environments: comparison of the subcutaneous and intravenous routes of administration. Journal of Pain \& Palliative Care Pharmacotherapy 2005;19(1):27-33.

\section{Lee 2009 \{published data only\}}

Lee Y, Koo J, Kim J, Park I, Joo M, Yoon J, et al. Effect of route of EPO administration on hemodialysis arteriovenous vascular access failure: a randomized controlled trial. American Journal of Kidney Diseases 2009;53(5):815-22.

\section{Mace 2013 \{published data only\}}

Mace SE, Harb G, Friend K, Turpin R, Armstrong EP, Lebel F. Costeffectiveness of recombinant human hyaluronidase-facilitated subcutaneous versus intravenous rehydration in children with mild to moderate dehydration. American Journal of Emergency Medicine 2013;31(6):928-34.

\section{Mahalanabis 1970 \{published data only\}}

Mahalanabis D, Sack RB, Kaplan J, Jacobs B, Mondal A. Intraperitoneal fluid therapy in cholera and non-cholera diarrhoea: with special emphasis on the treatment of infants and children. Bulletin of the World Health Organization 1970;42(6):837-46.

\section{Moulin 1991 \{published data only\}}

Moulin DE, Kreeft JH, Murray-Parsons N, Bouquillon AI. Comparison of continuous subcutaneous and intravenous hydromorphone infusions for management of cancer pain. Lancet 1991;337(8739):465-8.

\section{Nelson 1997 \{published data only\}}

Nelson KA, Glare PA, Walsh D, Groh ES. A prospective, withinpatient, crossover study of continuous intravenous and subcutaneous morphine for chronic cancer pain. Journal of Pain \& Symptom Management 1997;13(5):262-7.
Paxton 2009 \{published data only\}

Paxton JH, Knuth TE, Klausner HA. Proximal humerus intraosseous infusion: a preferred emergency venous access. Journal of Trauma 2009;67(3):606-11.

Rajani 2011 \{published data only\}

Rajani AK, Chitkara R, Oehlert J, Halamek LP. Comparison of umbilical venous and intraosseous access during simulated neonatal resuscitation. Pediatrics 2011;128(4):954-8.

\section{Ransome-Kuti 1969 \{published data only\}}

Ransome-Kuti O, Elebute O, Agusto-Odutola T, Ransome-Kuti S. Intraperitoneal fluid infusion in children with gastroenteritis. British Medical Journal 1969;3(5669):500-3.

Robinson 1993 \{published data only\}

Robinson AM, McLean KA, Greaves M, Channer KS. Subcutaneous versus intravenous administration of heparin in the treatment of deep vein thrombosis; which do patients prefer? A randomized cross-over study. Postgraduate Medical Journal 1993;69(808):115-6.

\section{Soremekun 2009 \{published data only\}}

Soremekun OA, Shear ML, Patel S, Kim GJ, Biddinger PD, Parry BA, et al. Rapid vascular glucose uptake via enzymeassisted subcutaneous infusion: enzyme-assisted subcutaneous infusion access study. American Journal of Emergency Medicine 2009;27(9):1072-80.

Tighe 1993 \{published data only\}

Tighe SQ, Rudland SV, Kemp PM, Kershaw CR. Paediatric resuscitation in adverse circumstances: a comparison of three routes of systemic access. Journal of the Royal Naval Medical Service 1993;79(2):75-9.

\section{Additional references}

\section{Deeks 2011}

Deeks JJ, Higgins JPT, Altman DG on behalf of the CSMG. Chapter 9: Analysing data and undertaking meta-analyses. In: Higgins JPT, Green S (editors). Cochrane Handbook for Systematic Reviews of Interventions Version 5.1.0 [updated March 2011]. The Cochrane Collaboration, 2011. Available from www.cochrane-handbook.org.

\section{Feldmann 2011}

Feldmann H, Geisbert TW. Ebola haemorrhagic fever. Lancet 2011;377(9768):849-62.

\section{Fowler 2014}

Fowler RA, Fletcher T, Fischer WA II, Lamontagne F, Jacob S, Brett-Major D, et al. Caring for critically ill patients with ebola virus disease. Perspectives from West Africa. American Journal of Respiratory and Critical Care Medicine 2014;190(7):733-7.

\section{GRADEpro 2014 [Computer program]}

McMaster University. GRADEpro. Hamilton, Ontario: McMaster University, 2014. 


\section{Higgins 2011a}

Higgins JPT, Altman DG, Sterne JAC on behalf of the CSMG and the CBMG. Chapter 8: Assessing risk of bias in included studies. In: Higgins JPT, Green S (editors). Cochrane Handbook for Systematic Reviews of Interventions Version 5.1.0 [updated March 2011]. The Cochrane Collaboration, 2011. Available from www.cochrane-handbook.org.

\section{Higgins 2011b}

Higgins JPT, Deeks JJ, Altman DG on behalf of the CSMG. Chapter 16: Special topics in statistics. In: Higgins JPT, Green $\mathrm{S}$ (editors). Cochrane Handbook for Systematic Reviews of Interventions Version 5.1.0 [updated March 2011]. The Cochrane Collaboration, 2011. Available from www.cochranehandbook.org.

\section{Hozo 2005}

Hozo SP, Djulbegovic B, Hozo I. Estimating the mean and variance from the median, range, and the size of a sample. BMC Medical Research Methodology 2005;5:13. [DOI: 10.1186/1471-2288-5-13]

\section{Kreuels 2014}

Kreuels B, Wichmann D, Emmerich P, Schmidt-Chanasit J, de Heer G, Kluge $S$, et al. A case of severe Ebola virus infection complicated by Gram-negative septicemia. New England Journal of Medicine 2014 Oct 22 [Epub ahead of print]. [DOI: 10.1056/NEJMoa1411677]

\section{Lefebvre 2011}

Lefebvre C, Manheimer E, Glanville J. Chapter 6: Searching for studies. In: Higgins JPT, Green S (editors). Cochrane Handbook for Systematic Reviews of Interventions Version 5.1.0 (updated March 2011). The Cochrane Collaboration, 2011. Available from www.cochrane-handbook.org.

\section{Remington 2007}

Remington R, Hultman T. Hypodermoclysis to treat dehydration: a review of the evidence. Journal of the American Geriatrics Society 2007;55:2051-5.

\section{Ribner 2014}

Ribner B. Ebola: Lessons Learned, from IDWeek 2014. http:// www.idweek.org/ebola_idweek_2014/ (accessed 24 October 2014).

\section{Rochon 1997}

Rochon PA, Gill SS, Litner J, Fischbach M, Goodison AJ, Gordon M. A systematic review of the evidence for hypodermoclysis to treat dehydration in older people. Journals of Gerontology. Series A, Biological Sciences and Medical Sciences 1997;52(3):M169-76

\section{Rouhani 2011}

Rouhani S, Meloney L, Ahn R, Nelson BD, Burke TF. Alternative rehydration methods: a systematic review and lessons for resource-limited care. Pediatrics 2011;127(3):748-57.

\section{Sanchez 2006}

Sanchez A, Geisbert TW, Feldmann H. Filoviridae: Marburg and Ebola viruses. In: Knipe DM, Howley PM editor(s). Fields Virology. 5th Edition. Philadelphia: Lippincott Williams \& Wilkins, 2006:1409-48.

\section{Schieffelin 2014}

Schieffelin JS, Shaffer JG, Goba A, Gbakie M, Gire SK, Colubri A, et al. Clinical illness and outcomes in patients with Ebola in Sierra Leone. New England Journal of Medicine 2014 Oct 29 [Epub ahead of print]. [DOI: 10.1056/NEJMoa1411680]

\section{Schünemann 2011}

Schünemann HJ, Oxman AD, Vist GE, Higgins JPT, Deeks JJ, Glasziou P, et al. Chapter 12: Interpreting results and drawing conclusions. In: Higgins JPT, Green S (editors). Cochrane Handbook for Systematic Reviews of Interventions Version 5.1.0 [updated March 2011]. The Cochrane Collaboration, 2011. Available from www.cochrane-handbook.org.

\section{TSA - Trial Sequential Analysis 0.9 Beta [Computer program]} Copenhagen Trial Unit, Center for Clinical Intervention Research, Rigshospitalet. TSA - Trial Sequential Analysis 0.9 Beta. Copenhagen: Copenhagen Trial Unit, Center for Clinical Intervention Research, Rigshospitalet, 2011.

\section{Waitt 2004}

Waitt C, Waitt P, Pirmohamed M. Review: Intravenous therapy. Postgraduate Medical Journal 2004;80:1-6.

\section{WHO 2014}

World Health Organization. Ebola virus disease: Fact sheet number 103 (updated September 2014). http://www.who.int/ mediacentre/factsheets/fs103/en/ (accessed 24 October 2014).

\section{WHO Ebola Response Team 2014}

WHO Ebola Response Team. Ebola virus disease in West Africa the first 9 months of the epidemic and forward projections. New England Journal of Medicine 2014;371(16):1481-95.

\section{References to other published versions of this review Ker 2014}

Ker K, Tansley G, Beecher D, Perner A, Shakur H, Harris T, Roberts I. Comparison of routes for achieving parenteral access with a focus on the management of patients with Ebola Virus Disease. Cochrane Database of Systematic Reviews 2014, Issue 11. [DOI: 10.1002/14651858.CD011386]

\section{CHARACTERISTICS OF STUDIES}

Characteristics of included studies [ordered by study ID] 
Banerjee 1994

\begin{tabular}{|c|c|}
\hline Methods & Parallel randomised trial \\
\hline Participants & $\begin{array}{l}\text { Setting: hospital emergency unit in Chandigarh, India } \\
60 \text { children (aged } 3 \text { months to } 2 \text { years) with severe dehydration due to diarrhoea and/or vomiting } \\
\text { - Intravenous group: }(n=30) ; M / F=N R ; \text { mean age (SEM) }=8.6(1.6) \text { months } \\
\text { - Intraosseous group: }(n=30) ; M / F=N R ; \text { mean age }(S E M)=8.9(2.0) \text { months }\end{array}$ \\
\hline Interventions & $\begin{array}{l}\text { - Intravenous group: } 22 \text { or } 24 \mathrm{G} \text { Teflon catheter, insertion site not specified } \\
\text { - Intraosseous group: } 18 \mathrm{G} \text { spinal needle with stylet or } 16 \text { to } 18 \mathrm{G} \text { hypodermic needle with stylet, inser- } \\
\text { tion site not specified } \\
\text { Both groups were infused with normal saline and/or } \mathrm{N} / 2 \text { saline in } 5 \% \text { dextrose with potassium } 20 \mathrm{mEQ} / \\
\mathrm{L} \text {, if not contraindicated. } \\
\text { Insertions were performed by paediatric residents with } 1 \text { year of clinical experience }\end{array}$ \\
\hline Outcomes & $\begin{array}{l}\text { Failure of route placement }{ }^{\wedge} \text {, defined as failure to secure route within } 5 \text { minutes of first attempt } \\
\text { Time taken to secure access }{ }^{\circ} \\
\text { Serum sodium }{ }^{\circ} \\
\text { Serum potassium }{ }^{\circ} \\
\text { Urea }^{\circ} \\
\text { Creatinine }^{\circ} \\
{ }^{\wedge} \text { data analysed as intention-to-treat } \\
{ }^{\circ} \text { data analysed as-treated }\end{array}$ \\
\hline Notes & - \\
\hline
\end{tabular}

\section{Risk of bias}

\begin{tabular}{lll}
\hline Bias & Authors' judgement & Support for judgement \\
\hline $\begin{array}{l}\text { Random sequence genera- } \\
\text { tion (selection bias) }\end{array}$ & High risk & Participants were "assigned alternately" \\
\hline $\begin{array}{l}\text { Allocation concealment } \\
\text { (selection bias) }\end{array}$ & High risk & Participants were "assigned alternately" \\
\hline $\begin{array}{l}\text { Blinding of participants } \\
\text { and personnel (perfor- } \\
\text { mance bias) }\end{array}$ & High risk & $\begin{array}{l}\text { Blinding not feasible. Likely that lack of blinding introduced bias, but unclear } \\
\text { in which direction the effect estimate would have been biased }\end{array}$ \\
\hline $\begin{array}{l}\text { Blinding of outcome as- } \\
\text { sessment (detection bias) } \\
\begin{array}{l}\text { Outcomes related to par- } \\
\text { enteral route insertion }\end{array}\end{array}$ & High risk & $\begin{array}{l}\text { Likely that lack of blinding biased the assessment of these outcomes; unclear } \\
\text { in which direction the results would have been biased }\end{array}$ \\
\hline $\begin{array}{l}\text { Blinding of outcome as- } \\
\text { sessment (detection bias) } \\
\text { Clinical outcomes }\end{array}$ & Low risk & $\begin{array}{l}\text { We judge that measurement of these outcomes is not likely to be influenced by } \\
\text { lack of blinding }\end{array}$ \\
\hline
\end{tabular}


Banerjee 1994 (Continued)

Blinding of outcome as- Unclear risk Data on these outcomes were not reported sessment (detection bias)

Subjective outcomes

\begin{tabular}{|c|c|c|}
\hline $\begin{array}{l}\text { Incomplete outcome data } \\
\text { (attrition bias) } \\
\text { Outcomes related to par- } \\
\text { enteral route insertion }\end{array}$ & High risk & $\begin{array}{l}\text { Access could not be secured in } 10 \text { patients in the IV group who were switched } \\
\text { to the IO group. Data on success of insertion were included in the meta-analy } \\
\text { sis on an intention-to-treat basis. Time for insertion data were presented and } \\
\text { are therefore included in the meta-analysis according to route received }\end{array}$ \\
\hline
\end{tabular}

\begin{tabular}{ll}
\hline $\begin{array}{l}\text { Incomplete outcome data } \\
\text { (attrition bias) }\end{array}$ & High risk \\
Data presented and therefore included in the meta-analysis according to the \\
route received
\end{tabular}

Clinical outcomes

Incomplete outcome data Unclear risk Data on these outcomes were not reported
(attrition bias)

Subjective outcomes

Selective reporting (re- Unclear risk Insufficient information to permit judgement
porting bias)

porting bias)

Boullu-Sanchis 2006

\begin{tabular}{ll}
\hline Methods & Parallel randomised trial \\
\hline Participants & Setting: diabetology department, France \\
& 37 patients hospitalised for uncontrolled type 2 diabetes \\
& - Intravenous group: $(\mathrm{n}=13) ; \mathrm{M} / \mathrm{F}=8 / 5 ;$ mean age $(\mathrm{SD})=57.9(2.6)$ \\
& - Subcutaneous group: $(\mathrm{n}=20) ; \mathrm{M} / \mathrm{F}=9 / 11 ;$ mean age $(\mathrm{SD})=59.0(1.5)$ \\
\hline Interventions & - Intravenous group: pump continuously administered solution of $0.4 \mathrm{ml}$ regular insulin in $39.6 \mathrm{ml}$ saline \\
& - Subcutaneous group: continuous infusion with intermittent bolus. Site changed every 3 days \\
& Unclear who performed the insertions \\
\hline Outcomes & Local site reactions ${ }^{\wedge}$ \\
& $\wedge$ data analysed as intention-to-treat \\
\hline Notes & -
\end{tabular}

\section{Risk of bias}

\begin{tabular}{lll}
\hline Bias & Authors' judgement & Support for judgement \\
\hline $\begin{array}{l}\text { Random sequence genera- } \\
\text { tion (selection bias) }\end{array}$ & Unclear risk & Described as "randomized by drawing to either group 1 or group 2" \\
\hline $\begin{array}{l}\text { Allocation concealment } \\
\text { (selection bias) }\end{array}$ & Unclear risk & Not described \\
\hline $\begin{array}{l}\text { Blinding of participants } \\
\text { and personnel (perfor- } \\
\text { mance bias) }\end{array}$ & High risk & $\begin{array}{l}\text { Blinding not feasible. Likely that lack of blinding introduced bias, but unclear } \\
\text { All outcomes }\end{array}$ \\
\hline \hline
\end{tabular}


Boullu-Sanchis 2006 (Continued)
Blinding of outcome as-
Unclear risk
Data on these outcomes were not reported sessment (detection bias)

Outcomes related to parenteral route insertion

\begin{tabular}{ll}
\hline Blinding of outcome as- & Unclear risk
\end{tabular}

Clinical outcomes

Blinding of outcome as-

High risk

Likely that lack of blinding biased the assessment of these outcomes; unclear sessment (detection bias)

Subjective outcomes in which direction the results would have been biased

Incomplete outcome data Unclear risk Data on these outcomes were not reported

(attrition bias)

Outcomes related to par-

enteral route insertion

\begin{tabular}{|c|c|c|}
\hline $\begin{array}{l}\text { Incomplete outcome data } \\
\text { (attrition bias) } \\
\text { Clinical outcomes }\end{array}$ & Unclear risk & Data on these outcomes were not reported \\
\hline $\begin{array}{l}\text { Incomplete outcome data } \\
\text { (attrition bias) } \\
\text { Subjective outcomes }\end{array}$ & Low risk & $\begin{array}{l}4 \text { patients ( } 2 \text { in each group) were excluded, however we judged that the rea- } \\
\text { sons for the missing data are unlikely to be related to outcome }\end{array}$ \\
\hline $\begin{array}{l}\text { Selective reporting (re- } \\
\text { porting bias) }\end{array}$ & Unclear risk & Insufficient information to permit judgement \\
\hline
\end{tabular}

Challiner 1994

\begin{tabular}{|c|c|}
\hline Methods & Parallel randomised trial \\
\hline \multirow[t]{4}{*}{ Participants } & Setting: elderly care unit, UK \\
\hline & $\begin{array}{l}34 \text { elderly stroke patients requiring parenteral nutrition because of impaired consciousness or dyspha- } \\
\text { gia }\end{array}$ \\
\hline & - Intravenous group: $(n=17) ; M / F=6 / 11 ;$ mean age (range) $=84.2(71$ to 95$)$ years \\
\hline & - Subcutaneous group: $(n=17) ; M / F=6 / 11 ;$ mean age (range) $=82.8$ (69 to 93 ) years \\
\hline \multirow[t]{4}{*}{ Interventions } & - Intravenous group: details of route not described \\
\hline & $\begin{array}{l}\text { - Subcutaneous group: } 10 \mathrm{G} \text { butterfly cannula sited on the trunk, axillary, scapular or thigh area. } 1500 \\
\text { units of hyaluronidase added to each bag if infusion ran behind time }\end{array}$ \\
\hline & Both groups infused with 2 litres of isotonic dextrose-saline per 24 hours over 3 days \\
\hline & Unclear who performed the insertions \\
\hline \multirow[t]{3}{*}{ Outcomes } & Local site reactions $^{\wedge}$ \\
\hline & Mortality^ \\
\hline & $\wedge$ data analysed as intention-to-treat \\
\hline Notes & - \\
\hline
\end{tabular}


Challiner 1994 (Continued)

Risk of bias

\begin{tabular}{lll}
\hline Bias & Authors' judgement & Support for judgement \\
\hline $\begin{array}{l}\text { Random sequence genera- } \\
\text { tion (selection bias) }\end{array}$ & Low risk & Computer-generated \\
\hline $\begin{array}{l}\text { Allocation concealment } \\
\text { (selection bias) }\end{array}$ & Low risk & Sequentially numbered, sealed envelopes \\
\hline $\begin{array}{l}\text { Blinding of participants } \\
\begin{array}{l}\text { and personnel (perfor- } \\
\text { mance bias) }\end{array}\end{array}$ & High risk & Blinding not feasible. Likely that lack of blinding introduced bias, but unclear \\
All outcomes & in which direction the results would have been biased
\end{tabular}

\begin{tabular}{lll}
\hline $\begin{array}{l}\text { Blinding of outcome as- } \\
\text { sessment (detection bias) } \\
\text { Outcomes related to par- } \\
\text { enteral route insertion }\end{array}$ & High risk & $\begin{array}{l}\text { Likely that lack of blinding biased the assessment of these outcomes; unclear } \\
\text { in which direction the results would have been biased }\end{array}$ \\
\hline $\begin{array}{l}\text { Blinding of outcome as- } \\
\text { sessment (detection bias) } \\
\begin{array}{l}\text { Clinical outcomes } \\
\hline\end{array}\end{array}$ & Low risk & $\begin{array}{l}\text { We judge that measurement of these outcomes is not likely to be influenced by } \\
\text { lack of blinding }\end{array}$ \\
\hline
\end{tabular}

\begin{tabular}{|c|c|c|}
\hline $\begin{array}{l}\text { Blinding of outcome as- } \\
\text { sessment (detection bias) } \\
\text { Subjective outcomes }\end{array}$ & High risk & $\begin{array}{l}\text { Likely that lack of blinding biased the assessment of these outcomes; unclear } \\
\text { in which direction the results would have been biased }\end{array}$ \\
\hline
\end{tabular}

\begin{tabular}{|c|c|c|}
\hline $\begin{array}{l}\text { Incomplete outcome data } \\
\text { (attrition bias) } \\
\text { Outcomes related to par- } \\
\text { enteral route insertion }\end{array}$ & High risk & $\begin{array}{l}2 \text { patients allocated to the subcutaneous group were excluded from the trial } \\
\text { analysis - } 1 \text { died and } 1 \text { developed local oedema }\end{array}$ \\
\hline $\begin{array}{l}\text { Incomplete outcome data } \\
\text { (attrition bias) } \\
\text { Clinical outcomes }\end{array}$ & Low risk & $\begin{array}{l}\text { Data for the patient in the subcutaneous group excluded from the trial analysis } \\
\text { have been included in the meta-analysis for the mortality outcome }\end{array}$ \\
\hline $\begin{array}{l}\text { Incomplete outcome data } \\
\text { (attrition bias) } \\
\text { Subjective outcomes }\end{array}$ & Low risk & $\begin{array}{l}\text { Data for the patient in the subcutaneous group excluded from the trial analysis } \\
\text { have been included in the meta-analysis for the local site reactions (oedema) } \\
\text { outcome }\end{array}$ \\
\hline
\end{tabular}

Selective reporting (re- Unclear risk Insufficient information to permit judgement
porting bias)

\section{Dardaine 1995}

\begin{tabular}{ll}
\hline Methods & Randomised cross-over trial \\
\hline Participants & Setting: hospital, France \\
& $\begin{array}{l}6 \text { hospitalised, elderly patients who had been admitted at least } 45 \text { days before, for rehabilitation after a } \\
\text { bone trauma requiring surgery }\end{array}$ \\
$M / F=1 / 5 ;$ mean age $(S D)=81.5(9.8)$ years
\end{tabular}

Interventions Intravenous group: administered into forearm vein


Dardaine 1995 (Continued)

- Subcutaneous group: administered into the anterior wall of the abdomen

Both groups infused with $1000 \mathrm{ml}$ of $5 \%$ glucose solution containing $4 \mathrm{~g} \mathrm{NaCl}$ over 6 hours

Unclear who performed the insertions

\begin{tabular}{ll}
\hline Outcomes & None of interest to this review \\
\hline Notes & -
\end{tabular}

\section{Risk of bias}

\begin{tabular}{lll}
\hline Bias & Authors' judgement & Support for judgement \\
\hline $\begin{array}{l}\text { Random sequence genera- } \\
\text { tion (selection bias) }\end{array}$ & Unclear risk & Not described \\
\hline $\begin{array}{l}\text { Allocation concealment } \\
\text { (selection bias) }\end{array}$ & Unclear risk & Not described \\
\hline
\end{tabular}

\begin{tabular}{|c|c|c|}
\hline $\begin{array}{l}\text { Blinding of participants } \\
\text { and personnel (perfor- } \\
\text { mance bias) } \\
\text { All outcomes }\end{array}$ & High risk & $\begin{array}{l}\text { Blinding not feasible. Likely that lack of blinding introduced bias, but unclear } \\
\text { in which direction the results would have been biased }\end{array}$ \\
\hline
\end{tabular}

Blinding of outcome assessment (detection bias) Outcomes related to parenteral route insertion
Likely that lack of blinding biased the assessment of these outcomes; unclear in which direction the results would have been biased

Blinding of outcome as- Unclear risk Data on this outcome were not reported

sessment (detection bias)

Clinical outcomes

\section{Blinding of outcome as- \\ sessment (detection bias) \\ Subjective outcomes}

Unclear risk

Data on this outcome were not reported

\begin{tabular}{ll}
\hline Incomplete outcome data Low risk & No exclusions described \\
(attrition bias)
\end{tabular}

Outcomes related to par-

enteral route insertion

\begin{tabular}{lll}
\hline $\begin{array}{l}\text { Incomplete outcome data } \\
\text { (attrition bias) } \\
\text { Clinical outcomes }\end{array}$ & Unclear risk & Data on this outcome were not reported \\
\hline $\begin{array}{l}\text { Incomplete outcome data } \\
\text { (attrition bias) } \\
\text { Subjective outcomes }\end{array}$ & Unclear risk & Data on this outcome were not reported \\
\hline $\begin{array}{l}\text { Selective reporting (re- } \\
\text { porting bias) }\end{array}$ & Unclear risk & Insufficient information to permit judgement \\
\hline
\end{tabular}


Delamaire 1992

\begin{tabular}{ll}
\hline Methods & Parallel randomised trial \\
\hline Participants & Setting: hospital, France \\
& 30 elderly patients (average 83 years) requiring rehydration (unable to take sufficient oral hydration) \\
& - Intravenous group: $(\mathrm{n}=15) ; \mathrm{M} / \mathrm{F}=6 / 11 ;$ mean age $(\mathrm{SD})=\mathrm{NR}$ \\
& - Subcutaneous group: $(\mathrm{n}=15) ; \mathrm{M} / \mathrm{F}=\mathrm{NR}$; mean age $(\mathrm{SD})=\mathrm{NR}$ \\
\hline Interventions & Intravenous group: \\
& Both groups infused with 1 litre solution of $2.5 \%$ glucose $+4.5 \mathrm{~g}$ sodium chloride \\
& Unclear who performed the insertions \\
\hline Outcomes & Failures of route replacement ${ }^{\wedge}$, definition of failure not described \\
& Local site reactions (oedema, infection)^ \\
& $\wedge$ data analysed as intention-to-treat \\
\hline Notes & - \\
\hline
\end{tabular}

\section{Risk of bias}

\begin{tabular}{lll}
\hline Bias & Authors' judgement & Support for judgement \\
\hline $\begin{array}{l}\text { Random sequence genera- } \\
\text { tion (selection bias) }\end{array}$ & Unclear risk & Not described \\
\hline $\begin{array}{l}\text { Allocation concealment } \\
\text { (selection bias) }\end{array}$ & Unclear risk & Not described \\
\hline $\begin{array}{l}\text { Blinding of participants } \\
\text { and personnel (perfor- } \\
\text { mance bias) }\end{array}$ & High risk & $\begin{array}{l}\text { Blinding not feasible. Likely that lack of blinding introduced bias, but unclear } \\
\text { ill outcomes }\end{array}$ \\
\hline
\end{tabular}

\begin{tabular}{ll}
\hline $\begin{array}{l}\text { Blinding of outcome as- } \\
\text { sessment (detection bias) } \\
\begin{array}{l}\text { Outcomes related to par- } \\
\text { enteral route insertion }\end{array}\end{array}$ & High risk
\end{tabular}

\begin{tabular}{|c|c|c|}
\hline $\begin{array}{l}\text { Blinding of outcome as- } \\
\text { sessment (detection bias) } \\
\text { Clinical outcomes }\end{array}$ & Unclear risk & Data on these outcomes were not reported \\
\hline $\begin{array}{l}\text { Blinding of outcome as- } \\
\text { sessment (detection bias) } \\
\text { Subjective outcomes }\end{array}$ & High risk & $\begin{array}{l}\text { Likely that lack of blinding biased the assessment of these outcomes; unclear } \\
\text { in which direction the results would have been biased }\end{array}$ \\
\hline $\begin{array}{l}\text { Incomplete outcome data } \\
\text { (attrition bias) } \\
\text { Outcomes related to par- } \\
\text { enteral route insertion }\end{array}$ & Low risk & No exclusions \\
\hline $\begin{array}{l}\text { Incomplete outcome data } \\
\text { (attrition bias) }\end{array}$ & Unclear risk & Data on these outcomes were not reported \\
\hline
\end{tabular}


Delamaire 1992 (Continued)

Clinical outcomes

Incomplete outcome data Low risk No exclusions
(attrition bias)

Subjective outcomes

Selective reporting (re- Unclear risk Insufficient information to permit judgement
porting bias)

Duems Noriega 2014

\begin{tabular}{ll}
\hline Methods & Parallel randomised trial \\
\hline Participants & Setting: hospital, Spain \\
& 70 patients with mild to moderate dehydration and oral intolerance, aged 65 years and older, admitted \\
& to hospital \\
- Intravenous group: $(n=33) ; M / F=20 / 14 ;$ mean age $(S D)=84.3(6.6)$ years \\
- Subcutaneous group: $(n=34) ; M / F=15 / 18 ;$ mean age $(S D)=86.4(8.5)$ years
\end{tabular}

Interventions

- Intravenous group: administered through catheters sited at back of the hand, forearm or inner elbow, avoiding previously damaged areas

- Subcutaneous group: 21 to $25 \mathrm{G}$ needles sited at inside of the thighs, lateral abdominal wall or the scapular region, avoiding previously damaged areas

Both groups infused up to 1.5 litres per 24 hours of either $\mathrm{NaCl} 0.9 \%$ or glucose $5 \%$ or mixed solution (saline $0.45 \%+$ glucose $5 \%$ ). $20 \mathrm{mEq}$ of potassium chloride could be added per litre

Unclear who performed the insertions

\begin{tabular}{ll}
\hline Outcomes & Dislodgements^ \\
& Local site reactions (oedema, infection)^ \\
& Mortality^ \\
& Patient discomfort (agitation)^ \\
& Volume of fluid infused ${ }^{\wedge}$ \\
& Creatinine \\
& Urea^ \\
& $\wedge$ data analysed as intention-to-treat \\
\hline Notes & Trial report in Spanish \\
\hline
\end{tabular}

\section{Risk of bias}

\begin{tabular}{lll}
\hline Bias & Authors' judgement & Support for judgement \\
\hline $\begin{array}{l}\text { Random sequence genera- } \\
\text { tion (selection bias) }\end{array}$ & Unclear risk & Not described \\
\hline $\begin{array}{l}\text { Allocation concealment } \\
\text { (selection bias) }\end{array}$ & Unclear risk & $\begin{array}{l}\text { Randomisation by mixed blocks of } 6 \text { sealed envelopes. Each block with 3 cards } \\
\text { with the treatment IV and 3 with SC }\end{array}$ \\
\hline
\end{tabular}


Duems Noriega 2014 (Continued)

$\begin{array}{ll}\begin{array}{l}\text { Blinding of participants } \\ \text { and personnel (perfor- }\end{array} & \text { High risk } \\ \text { in which direction the results would have been biased }\end{array}$
in which direction the results would have been biased mance bias)

All outcomes

Blinding of outcome as- $\quad$ High risk
sessment (detection bias)
Outcomes related to par-
enteral route insertion

Likely that lack of blinding biased the assessment of these outcomes; unclear in which direction the results would have been biased

\begin{tabular}{|c|c|c|}
\hline $\begin{array}{l}\text { Blinding of outcome as- } \\
\text { sessment (detection bias) } \\
\text { Clinical outcomes }\end{array}$ & Low risk & $\begin{array}{l}\text { We judge that measurement of these outcomes is not likely to be influenced by } \\
\text { lack of blinding }\end{array}$ \\
\hline
\end{tabular}

\begin{tabular}{|c|c|c|}
\hline $\begin{array}{l}\text { Blinding of outcome as- } \\
\text { sessment (detection bias) }\end{array}$ & High risk & $\begin{array}{l}\text { Likely that lack of blinding biased the assessment of these outcomes; unclear } \\
\text { in which direction the results would have been biased }\end{array}$ \\
\hline
\end{tabular}

\begin{tabular}{ll} 
Subjective outcomes & \\
\hline $\begin{array}{l}\text { Incomplete outcome data } \\
\text { (attrition bias) } \\
\text { Outcomes related to par- }\end{array}$ & $\begin{array}{l}3 \text { patients who died during the study period were excluded from the trial } \\
\text { analysis }\end{array}$
\end{tabular}

\section{Outcomes related to par-}

enteral route insertion

\begin{tabular}{ll}
\hline $\begin{array}{l}\text { Incomplete outcome data } \\
\text { (attrition bias) }\end{array}$ & $\begin{array}{l}\text { Data for the } 3 \text { patients ( } 2 \text { in the intravenous group, } 1 \text { in the subcutaneous } \\
\text { group) who died during the study period were excluded from the trial analysis. }\end{array}$ \\
Clinical outcomes & These data have been included in the meta-analysis for the mortality outcome. \\
& However, risk of bias remains for renal function outcomes
\end{tabular}

\begin{tabular}{|c|c|c|}
\hline $\begin{array}{l}\text { Incomplete outcome data } \\
\text { (attrition bias) } \\
\text { Subjective outcomes }\end{array}$ & High risk & $\begin{array}{l}3 \text { patients who died during the study period were excluded from the trial } \\
\text { analysis }\end{array}$ \\
\hline $\begin{array}{l}\text { Selective reporting (re- } \\
\text { porting bias) }\end{array}$ & Unclear risk & Insufficient information to permit judgement \\
\hline
\end{tabular}

\begin{tabular}{|c|c|}
\hline Methods & Randomised cross-over trial \\
\hline \multirow[t]{3}{*}{ Participants } & Setting: Aarhus University Hospital, Denmark \\
\hline & 10 intravenous immunoglobulin responsive patients with multifocal motor neuropathy \\
\hline & $M / F=4 / 5 ;$ mean age $(S D)=49.2(10.51)$ years \\
\hline \multirow[t]{4}{*}{ Interventions } & $\begin{array}{l}\text { - Intravenous group: administered during hospital admission through a permanent IV catheter inserted } \\
\text { into the subclavian vein }(n=2) \text { or peripheral vein }(n=7)\end{array}$ \\
\hline & $\begin{array}{l}\text { - Subcutaneous group: syringe pump and butterfly needle into tissue at the abdominal wall. Received } \\
80 \text { to } 155 \mathrm{ml} \text { at } 4 \text { to } 8 \text { injection sites each week at an infusion time of } 2 \text { to } 4 \text { hours }\end{array}$ \\
\hline & Both groups infused with immunoglobulin \\
\hline & $\begin{array}{l}\text { Unclear who performed the IV insertions; SC insertions performed initially by nurse and then were self } \\
\text { administered }\end{array}$ \\
\hline Outcomes & Local site reactions (erythema, oedema, infection) ${ }^{\wedge \varsigma}$ \\
\hline
\end{tabular}


Harbo 2009 (Continued)

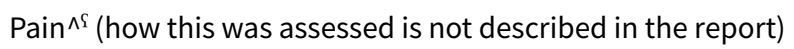

$\wedge$ data analysed as intention-to-treat

¿data included in review as a parallel trial; this approach leads to a unit of analysis error, causing the Cls to be too wide and the trial to receive too little weight

Notes -

\section{Risk of bias}

\begin{tabular}{lll}
\hline Bias & Authors' judgement & Support for judgement \\
\hline $\begin{array}{l}\text { Random sequence genera- } \\
\text { tion (selection bias) }\end{array}$ & Unclear risk & Not described \\
\hline
\end{tabular}

\begin{tabular}{lll}
\hline $\begin{array}{l}\text { Allocation concealment } \\
\text { (selection bias) }\end{array}$ & Low risk & Pharmacy-controlled \\
\hline $\begin{array}{l}\text { Blinding of participants } \\
\text { and personnel (perfor- } \\
\text { mance bias) }\end{array}$ & High risk & $\begin{array}{l}\text { Blinding not feasible. Likely that lack of blinding introduced bias, but unclear } \\
\text { in which direction the results would have been biased }\end{array}$ \\
All outcomes & \\
\hline
\end{tabular}

\begin{tabular}{ll}
\hline Blinding of outcome as- & Unclear risk Data on these outcomes were not reported \\
sessment (detection bias) & \\
Outcomes related to par- \\
enteral route insertion
\end{tabular}

\begin{tabular}{|c|c|c|}
\hline $\begin{array}{l}\text { Blinding of outcome as- } \\
\text { sessment (detection bias) } \\
\text { Clinical outcomes }\end{array}$ & Unclear risk & Not applicable (trial does not involve fluid administration) \\
\hline $\begin{array}{l}\text { Blinding of outcome as- } \\
\text { sessment (detection bias) } \\
\text { Subjective outcomes }\end{array}$ & High risk & $\begin{array}{l}\text { Likely that lack of blinding biased the assessment of these outcomes; unclear } \\
\text { in which direction the results would have been biased }\end{array}$ \\
\hline
\end{tabular}

\begin{tabular}{|c|c|c|}
\hline $\begin{array}{l}\text { Incomplete outcome data } \\
\text { (attrition bias) } \\
\text { Outcomes related to par- } \\
\text { enteral route insertion }\end{array}$ & Unclear risk & Data on these outcomes were not reported \\
\hline $\begin{array}{l}\text { Incomplete outcome data } \\
\text { (attrition bias) } \\
\text { Clinical outcomes }\end{array}$ & Unclear risk & Data on these outcomes were not reported \\
\hline $\begin{array}{l}\text { Incomplete outcome data } \\
\text { (attrition bias) } \\
\text { Subjective outcomes }\end{array}$ & Low risk & No post-randomisation exclusions \\
\hline $\begin{array}{l}\text { Selective reporting (re- } \\
\text { porting bias) }\end{array}$ & Unclear risk & $\begin{array}{l}\text { Registered after start of recruitment (NCT00268788). Adverse events listed as a } \\
\text { secondary outcomes }\end{array}$ \\
\hline
\end{tabular}

Methods Randomised cross-over trial


Harvey 1987 (Continued)

\begin{tabular}{l} 
Setting: London, UK \\
Participants \\
M/F = NR; mean age (SD) = NR \\
\hline - Intravenous group: into forearm vein via Teflon catheter \\
- Subcutaneous group: into anterior abdominal wall via $25 \mathrm{G}$ steel needle \\
15 mg bleomycin in saline with 100 mg hydrocortisone \\
Unclear who performed the insertions
\end{tabular}

Outcomes Local site reactions, although insufficient data presented for meta-analysis

Notes -

\section{Risk of bias}

\begin{tabular}{|c|c|c|}
\hline Bias & Authors' judgement & Support for judgement \\
\hline $\begin{array}{l}\text { Random sequence genera- } \\
\text { tion (selection bias) }\end{array}$ & Unclear risk & Not described \\
\hline $\begin{array}{l}\text { Allocation concealment } \\
\text { (selection bias) }\end{array}$ & Unclear risk & Not described \\
\hline $\begin{array}{l}\text { Blinding of participants } \\
\text { and personnel (perfor- } \\
\text { mance bias) } \\
\text { All outcomes }\end{array}$ & High risk & $\begin{array}{l}\text { Blinding not feasible. Likely that lack of blinding introduced bias, but unclear } \\
\text { in which direction the results would have been biased }\end{array}$ \\
\hline $\begin{array}{l}\text { Blinding of outcome as- } \\
\text { sessment (detection bias) } \\
\text { Outcomes related to par- } \\
\text { enteral route insertion }\end{array}$ & Unclear risk & Data on these outcomes were not reported \\
\hline $\begin{array}{l}\text { Blinding of outcome as- } \\
\text { sessment (detection bias) } \\
\text { Clinical outcomes }\end{array}$ & Unclear risk & Not applicable (trial does not involve fluid administration) \\
\hline $\begin{array}{l}\text { Blinding of outcome as- } \\
\text { sessment (detection bias) } \\
\text { Subjective outcomes }\end{array}$ & High risk & $\begin{array}{l}\text { Likely that lack of blinding biased the assessment of these outcomes; unclear } \\
\text { in which direction the results would have been biased }\end{array}$ \\
\hline $\begin{array}{l}\text { Incomplete outcome data } \\
\text { (attrition bias) } \\
\text { Outcomes related to par- } \\
\text { enteral route insertion }\end{array}$ & Unclear risk & Data on these outcomes were not reported \\
\hline $\begin{array}{l}\text { Incomplete outcome data } \\
\text { (attrition bias) } \\
\text { Clinical outcomes }\end{array}$ & Unclear risk & Data on these outcomes were not reported \\
\hline $\begin{array}{l}\text { Incomplete outcome data } \\
\text { (attrition bias) } \\
\text { Subjective outcomes }\end{array}$ & Unclear risk & $\begin{array}{l}\text { No exclusions reported, although presented data were insufficient for meta- } \\
\text { analysis }\end{array}$ \\
\hline
\end{tabular}


Harvey 1987 (Continued)

Selective reporting (re- Unclear risk Insufficient information to permit judgement porting bias)

Hubble 2001

\begin{tabular}{|c|c|}
\hline Methods & Randomised cross-over trial \\
\hline \multirow[t]{3}{*}{ Participants } & Setting: hospital training laboratory, USA \\
\hline & $\begin{array}{l}13 \text { students of the senior class of baccalaureate degree paramedical programme, recently trained in } \\
\text { both methods }\end{array}$ \\
\hline & $M / F=N R ;$ mean age $(S D)=N R$ \\
\hline \multirow[t]{4}{*}{ Interventions } & $\begin{array}{l}\text { - Saphenous vein cutdown: at the ankle in a cadaver using standard technique with insertion of an IV } \\
\text { cannula under direct visualisation }\end{array}$ \\
\hline & - Intraosseous group: using the $\mathrm{BIG}^{\circledR}$ into the proximal tibia of a cadaver \\
\hline & Both access routes connected to a $1000 \mathrm{ml}$ bag of $\mathrm{NaCl}$ solution \\
\hline & Insertions performed by members of senior class of a baccalaureate degree paramedical programme \\
\hline \multirow[t]{4}{*}{ Outcomes } & Failure of route placement ${ }^{\wedge \varsigma}$ (defined as inability to initiate fluid flow) \\
\hline & Time to infusion^^ \\
\hline & $\wedge$ data analysed as intention-to-treat \\
\hline & $\begin{array}{l}\text { 'data included in review as a parallel trial; this approach leads to a unit of analysis error, causing the Cls } \\
\text { to be too wide and the trial to receive too little weight }\end{array}$ \\
\hline Notes & - \\
\hline
\end{tabular}

\section{Risk of bias}

\begin{tabular}{|c|c|c|}
\hline Bias & Authors' judgement & Support for judgement \\
\hline $\begin{array}{l}\text { Random sequence genera- } \\
\text { tion (selection bias) }\end{array}$ & Unclear risk & Not described \\
\hline $\begin{array}{l}\text { Allocation concealment } \\
\text { (selection bias) }\end{array}$ & Unclear risk & Not described \\
\hline $\begin{array}{l}\text { Blinding of participants } \\
\text { and personnel (perfor- } \\
\text { mance bias) } \\
\text { All outcomes }\end{array}$ & High risk & $\begin{array}{l}\text { Blinding not feasible. Likely that lack of blinding introduced bias, but unclear } \\
\text { in which direction the results would have been biased }\end{array}$ \\
\hline $\begin{array}{l}\text { Blinding of outcome as- } \\
\text { sessment (detection bias) } \\
\text { Outcomes related to par- } \\
\text { enteral route insertion }\end{array}$ & High risk & $\begin{array}{l}\text { Likely that lack of blinding biased the assessment of these outcomes; unclear } \\
\text { in which direction the results would have been biased }\end{array}$ \\
\hline $\begin{array}{l}\text { Blinding of outcome as- } \\
\text { sessment (detection bias) } \\
\text { Clinical outcomes }\end{array}$ & Unclear risk & Not applicable (simulated using a cadaver) \\
\hline
\end{tabular}


Hubble 2001 (Continued)

Blinding of outcome as- Unclear risk Data on these outcomes were not reported sessment (detection bias)

Subjective outcomes

Incomplete outcome data Low risk No exclusions
(attrition bias)
Outcomes related to par-
enteral route insertion

\begin{tabular}{lll}
\hline $\begin{array}{l}\text { Incomplete outcome data } \\
\text { (attrition bias) } \\
\text { Clinical outcomes }\end{array}$ & Unclear risk & Not applicable (simulated using a cadaver) \\
\hline $\begin{array}{l}\text { Incomplete outcome data } \\
\begin{array}{l}\text { (attrition bias) } \\
\text { Subjective outcomes }\end{array}\end{array}$ & Low risk & No exclusions \\
\hline $\begin{array}{l}\text { Selective reporting (re- } \\
\text { porting bias) }\end{array}$ & Unclear risk & Insufficient information to permit judgement \\
\hline
\end{tabular}

\section{Hägglund 1998}

\begin{tabular}{|c|c|c|}
\hline Methods & \multicolumn{2}{|c|}{ Parallel randomised trial } \\
\hline Participants & \multicolumn{2}{|c|}{$\begin{array}{l}\text { Setting: Huddinge Hospital, Sweden } \\
38 \text { adult patients receiving bone marrow transplants from related donor } \\
\text { - Intravenous group: }(n=20) ; M / F=N R ; \text { median age (range) }=38 \text { (19 to } 54) \text { years } \\
\text { - Intraosseous group: }(n=9) ; M / F=N R ; \text { median age (range) }=38(20 \text { to } 50) \text { years }\end{array}$} \\
\hline Interventions & \multicolumn{2}{|c|}{$\begin{array}{l}\text { - Intravenous group: details of route not described } \\
\text { - Intraosseous group: } 2 \text { bone marrow aspiration ne } \\
\text { crests under local anaesthesia. Infusion given with } \\
\text { Both groups infused with bone marrow } \\
\text { Unclear who performed the insertions }\end{array}$} \\
\hline Outcomes & \multicolumn{2}{|c|}{$\begin{array}{l}\text { Local site reactions (infection) }{ }^{\mathrm{s}} \\
\text { "data not analysed on an intention-to-treat basis; data on patient who switched treatment excluded } \\
\text { from trial analysis }\end{array}$} \\
\hline Notes & \multicolumn{2}{|l|}{-} \\
\hline \multicolumn{3}{|l|}{ Risk of bias } \\
\hline Bias & Authors' judgement & Support for judgement \\
\hline $\begin{array}{l}\text { Random sequence genera- } \\
\text { tion (selection bias) }\end{array}$ & Unclear risk & Not described \\
\hline $\begin{array}{l}\text { Allocation concealment } \\
\text { (selection bias) }\end{array}$ & Unclear risk & Not described \\
\hline
\end{tabular}


Hägglund 1998 (Continued)

Blinding of participants High risk Blinding not feasible. Likely that lack of blinding introduced bias, but unclear and personnel (perforin which direction the results would have been biased mance bias)

All outcomes

\begin{tabular}{|c|c|c|}
\hline $\begin{array}{l}\text { Blinding of outcome as- } \\
\text { sessment (detection bias) } \\
\text { Outcomes related to par- } \\
\text { enteral route insertion }\end{array}$ & Unclear risk & Data on these outcomes were not reported \\
\hline $\begin{array}{l}\text { Blinding of outcome as- } \\
\text { sessment (detection bias) } \\
\text { Clinical outcomes }\end{array}$ & Unclear risk & Not applicable (trial does not involve fluid administration) \\
\hline $\begin{array}{l}\text { Blinding of outcome as- } \\
\text { sessment (detection bias) } \\
\text { Subjective outcomes }\end{array}$ & High risk & $\begin{array}{l}\text { Likely that lack of blinding biased the assessment of these outcomes; unclear } \\
\text { in which direction the results would have been biased }\end{array}$ \\
\hline $\begin{array}{l}\text { Incomplete outcome data } \\
\text { (attrition bias) } \\
\text { Outcomes related to par- } \\
\text { enteral route insertion }\end{array}$ & Unclear risk & Data on these outcomes were not reported \\
\hline $\begin{array}{l}\text { Incomplete outcome data } \\
\text { (attrition bias) } \\
\text { Clinical outcomes }\end{array}$ & Unclear risk & Not applicable (trial does not involve fluid administration) \\
\hline $\begin{array}{l}\text { Incomplete outcome data } \\
\text { (attrition bias) } \\
\text { Subjective outcomes }\end{array}$ & High risk & $\begin{array}{l}\text { Apparent from the report that } 1 \text { patient in the } 10 \text { group switched to receive half } \\
\text { the volume as an IV infusion because of severe pain and was excluded from the } \\
\text { analysis }\end{array}$ \\
\hline $\begin{array}{l}\text { Selective reporting (re- } \\
\text { porting bias) }\end{array}$ & Unclear risk & Insufficient information to permit judgement \\
\hline
\end{tabular}

Lamhaut 2010 (no PPE)

\begin{tabular}{|c|c|}
\hline Methods & Randomised cross-over trial \\
\hline Participants & $\begin{array}{l}\text { Setting: pre-hospital department of a hospital, France } \\
25 \text { pre-hospital emergency professionals ( } 9 \text { nurses and } 16 \text { physicians) } \\
M / F=N R ; \text { mean age (SD) = NR }\end{array}$ \\
\hline Interventions & $\begin{array}{l}\text { - Intravenous group: single-use } 18 \mathrm{G} \text { peripheral intravenous catheter inserted into a training manikin } \\
\text { - Intravenous group + } \mathrm{CBRN} \text { : as above while wearing } \mathrm{CBRN} \text { protective equipment } \\
\text { - Intraosseous group: using } \mathrm{EZ-IO} \mathrm{I}^{\circledR} 15 \mathrm{G} \text { needle inserted into training manikin } \\
\text { - Intraosseous group + CBRN: as above while wearing CBRN protective equipment } \\
\text { Both access routes connected to bag of fluid solution } \\
\text { Insertions performed by pre-hospital emergency professionals ( } 9 \text { nurses and } 16 \text { physicians) }\end{array}$ \\
\hline Outcomes & $\begin{array}{l}\text { Insertion failures^, not clearly defined, described only as "failure of an IV or IO access attempt, includ- } \\
\text { ing the case of absence of fluid after connection of the infusion line to the vascular access" } \\
\text { Time to infusion^ }\end{array}$ \\
\hline
\end{tabular}


Lamhaut 2010 (no PPE) (Continued)

${ }^{\wedge}$ data analysed as intention-to-treat

\begin{tabular}{ll}
\hline Notes & - \\
\hline
\end{tabular}

\section{Risk of bias}

\begin{tabular}{lll}
\hline Bias & Authors' judgement & Support for judgement \\
\hline $\begin{array}{l}\text { Random sequence genera- } \\
\text { tion (selection bias) }\end{array}$ & Low risk & Computer-generated randomisation \\
\hline $\begin{array}{l}\text { Allocation concealment } \\
\text { (selection bias) }\end{array}$ & Unclear risk & Not described \\
\hline $\begin{array}{l}\text { Blinding of participants } \\
\text { and personnel (perfor- } \\
\text { mance bias) }\end{array}$ & High risk & $\begin{array}{l}\text { Blinding not feasible. Likely that lack of blinding introduced bias, but unclear } \\
\text { All outcomes }\end{array}$ \\
\hline
\end{tabular}

\begin{tabular}{ll}
\hline $\begin{array}{l}\text { Blinding of outcome as- } \\
\text { sessment (detection bias) } \\
\begin{array}{l}\text { Outcomes related to par- } \\
\text { enteral route insertion }\end{array}\end{array}$ & High risk
\end{tabular}

\begin{tabular}{|c|c|c|}
\hline $\begin{array}{l}\text { Blinding of outcome as- } \\
\text { sessment (detection bias) } \\
\text { Clinical outcomes }\end{array}$ & Unclear risk & Not applicable (simulated using manikin) \\
\hline
\end{tabular}

\begin{tabular}{lll}
\hline Blinding of outcome as- & Unclear risk Data on these outcomes were not reported \\
sessment (detection bias) &
\end{tabular}

Subjective outcomes

Incomplete outcome data Low risk No exclusions
(attrition bias)
Outcomes related to par-
enteral route insertion

Incomplete outcome data Unclear risk Not applicable (simulated using a manikin)
(attrition bias)

Clinical outcomes

Incomplete outcome data Unclear risk Data on these outcomes were not reported

(attrition bias)

Subjective outcomes

Selective reporting (re- Unclear risk Insufficient information to permit judgement
porting bias)

Lamhaut 2010 (with PPE)

\begin{tabular}{ll}
\hline Methods & Randomised cross-over trial \\
\hline Participants & Setting: pre-hospital department of a hospital, France \\
& 25 pre-hospital emergency professionals (9 nurses and 16 physicians)
\end{tabular}


Lamhaut 2010 (with PPE) (Continued)

$$
\mathrm{M} / \mathrm{F}=\mathrm{NR} \text {; mean age }(\mathrm{SD})=\mathrm{NR}
$$

Interventions $\quad$ Intravenous group + CBRN: as above while wearing CBRN protective equipment
- Intraosseous group + CBRN: as above while wearing CBRN protective equipment
Both access routes connected to bag of fluid solution

\begin{tabular}{ll} 
Outcomes & $\begin{array}{l}\text { Insertion failures } \\
\text { ing the case of absence of fluid after connection of the infusion line to the vascular access" }\end{array}$ \\
& Time to infusion^ \\
& $\wedge$ data analysed as intention-to-treat \\
\hline Notes & -
\end{tabular}

\section{Risk of bias}

\begin{tabular}{lll}
\hline Bias & Authors' judgement & Support for judgement \\
\hline $\begin{array}{l}\text { Random sequence genera- } \\
\text { tion (selection bias) }\end{array}$ & Low risk & Computer-generated randomisation \\
\hline $\begin{array}{l}\text { Allocation concealment } \\
\text { (selection bias) }\end{array}$ & Unclear risk & Not described \\
\hline
\end{tabular}

\begin{tabular}{|c|c|c|}
\hline $\begin{array}{l}\text { Blinding of participants } \\
\text { and personnel (perfor- } \\
\text { mance bias) } \\
\text { All outcomes }\end{array}$ & High risk & $\begin{array}{l}\text { Blinding not feasible. Likely that lack of blinding introduced bias, but unclear } \\
\text { in which direction the results would have been biased }\end{array}$ \\
\hline
\end{tabular}

\section{Blinding of outcome as-} sessment (detection bias) Outcomes related to parenteral route insertion
Likely that lack of blinding biased the assessment of these outcomes; unclear in which direction the results would have been biased

\begin{tabular}{|c|c|c|}
\hline $\begin{array}{l}\text { Blinding of outcome as- } \\
\text { sessment (detection bias) } \\
\text { Clinical outcomes }\end{array}$ & Unclear risk & Not applicable (trial does not involve fluid administration) \\
\hline
\end{tabular}

\begin{tabular}{|c|c|c|}
\hline $\begin{array}{l}\text { Blinding of outcome as- } \\
\text { sessment (detection bias) } \\
\text { Subjective outcomes }\end{array}$ & Unclear risk & Data on these outcomes were not reported \\
\hline $\begin{array}{l}\text { Incomplete outcome data } \\
\text { (attrition bias) } \\
\text { Outcomes related to par- } \\
\text { enteral route insertion }\end{array}$ & Low risk & No exclusions \\
\hline $\begin{array}{l}\text { Incomplete outcome data } \\
\text { (attrition bias) } \\
\text { Clinical outcomes }\end{array}$ & Unclear risk & Not applicable (trial does not involve fluid administration) \\
\hline $\begin{array}{l}\text { Incomplete outcome data } \\
\text { (attrition bias) } \\
\text { Subjective outcomes }\end{array}$ & Unclear risk & Data on these outcomes were not reported \\
\hline $\begin{array}{l}\text { Selective reporting (re- } \\
\text { porting bias) }\end{array}$ & Unclear risk & Insufficient information to permit judgement \\
\hline
\end{tabular}


Liebl 2009

\begin{tabular}{|c|c|}
\hline Methods & Randomised cross-over trial \\
\hline \multirow[t]{4}{*}{ Participants } & Setting: centres in Netherlands, France, Austria, Germany and Switzerland \\
\hline & $61^{*}$ patients with type 1 diabetes with frequent hypoglycaemia and/or $\mathrm{HbAlc}>7.0 \%$ \\
\hline & $\mathrm{M} / \mathrm{F}=44 / 16 ;$ mean age $(\mathrm{SD})=50.5(10.8)$ years \\
\hline & ( ${ }^{\star} 1$ patient excluded) \\
\hline \multirow[t]{3}{*}{ Interventions } & $\begin{array}{l}\text { - Intraperitoneal: using the DiaPort system, implanted under general anaesthesia into the subcuta- } \\
\text { neous tissue of the abdominal wall. Insulin is infused into the abdominal cavity }\end{array}$ \\
\hline & - Subcutaneous group: continuous infusion of insulin lispro \\
\hline & Unclear who performed the insertions \\
\hline \multirow[t]{3}{*}{ Outcomes } & Local site reactions (infections and inflammations) $^{\circ}$ \\
\hline & Pain $^{\circ}$ (how this was assessed is not described in the report) \\
\hline & ${ }^{\circ}$ data analysed as-treated \\
\hline Notes & - \\
\hline
\end{tabular}

\section{Risk of bias}

\begin{tabular}{|c|c|c|}
\hline Bias & Authors' judgement & Support for judgement \\
\hline $\begin{array}{l}\text { Random sequence genera- } \\
\text { tion (selection bias) }\end{array}$ & Unclear risk & Not described \\
\hline $\begin{array}{l}\text { Allocation concealment } \\
\text { (selection bias) }\end{array}$ & Unclear risk & Not described \\
\hline $\begin{array}{l}\text { Blinding of participants } \\
\text { and personnel (perfor- } \\
\text { mance bias) } \\
\text { All outcomes }\end{array}$ & High risk & $\begin{array}{l}\text { Blinding not feasible. Likely that lack of blinding introduced bias, but unclear } \\
\text { in which direction the results would have been biased }\end{array}$ \\
\hline $\begin{array}{l}\text { Blinding of outcome as- } \\
\text { sessment (detection bias) } \\
\text { Outcomes related to par- } \\
\text { enteral route insertion }\end{array}$ & Unclear risk & Data on these outcomes were not reported \\
\hline $\begin{array}{l}\text { Blinding of outcome as- } \\
\text { sessment (detection bias) } \\
\text { Clinical outcomes }\end{array}$ & Unclear risk & Not applicable (trial does not involve fluid administration) \\
\hline $\begin{array}{l}\text { Blinding of outcome as- } \\
\text { sessment (detection bias) } \\
\text { Subjective outcomes }\end{array}$ & High risk & $\begin{array}{l}\text { Likely that lack of blinding biased the assessment of these outcomes; unclear } \\
\text { in which direction the results would have been biased }\end{array}$ \\
\hline $\begin{array}{l}\text { Incomplete outcome data } \\
\text { (attrition bias) } \\
\text { Outcomes related to par- } \\
\text { enteral route insertion }\end{array}$ & Unclear risk & Data on these outcomes were not reported \\
\hline
\end{tabular}


Liebl 2009 (Continued)

Incomplete outcome data Unclear risk Not applicable (trial does not involve fluid administration)

(attrition bias)

Clinical outcomes

\begin{tabular}{lll}
\hline $\begin{array}{l}\text { Incomplete outcome data } \\
\text { (attrition bias) } \\
\text { Subjective outcomes }\end{array}$ & High risk & $\begin{array}{l}\text { Large number of dropouts during study - 15 IP patients and } 9 \text { SC patients } \\
\text { dropped out during first treatment period followed by } 9 \text { IP patients and } 3 \text { SC } \\
\text { patients during the second treatment period }\end{array}$ \\
\hline $\begin{array}{l}\text { Selective reporting (re- } \\
\text { porting bias) }\end{array}$ & Unclear risk & Insufficient information to permit judgement \\
\hline
\end{tabular}

\section{O'Keeffe 1996}

\begin{tabular}{|c|c|}
\hline Methods & Parallel randomised trial \\
\hline \multirow[t]{4}{*}{ Participants } & Setting: acute geriatric unit, UK \\
\hline & $\begin{array}{l}60 \text { elderly patients with cognitive impairment judged to require parenteral fluids for at least } 48 \text { hours } \\
\text { because of mild dehydration or poor oral intake }\end{array}$ \\
\hline & - Intravenous group: $(n=30) ; M / F=13 / 17 ;$ mean age $(S D)=84(7)$ years \\
\hline & - Subcutaneous group: $(n=30) ; M / F=10 / 20 ;$ mean age $(S D)=81(6)$ years \\
\hline \multirow[t]{4}{*}{ Interventions } & - Intravenous group: administered through an 18 or $20 \mathrm{G}$ cannula in forearm vein \\
\hline & $\begin{array}{l}\text { - Subcutaneous group: administered in the infraclavicular, scapular, abdominal or thigh areas through } \\
\text { a } 21 \mathrm{G} \text { butterfly cannula }\end{array}$ \\
\hline & Up to 2 litres of any combination of $0.9 \%$ normal saline, $0.45 \%$ normal saline and $5 \%$ dextrose \\
\hline & Unclear who performed the insertions \\
\hline \multirow[t]{4}{*}{ Outcomes } & Local site reactions (oedema) ${ }^{\mathrm{s}}$ \\
\hline & Patient discomfort (agitation related to cannula or drip) ${ }^{\mathrm{s}}$ \\
\hline & Volume of fluids infused ${ }^{\mathrm{s}}$ \\
\hline & $\begin{array}{l}{ }^{ } \text {data not analysed on an intention-to-treat basis; data on patient who switched treatment excluded from } \\
\text { trial analysis }\end{array}$ \\
\hline
\end{tabular}

\section{Notes}

\section{Risk of bias}

\begin{tabular}{lll}
\hline Bias & Authors' judgement & Support for judgement \\
\hline $\begin{array}{l}\text { Random sequence genera- } \\
\text { tion (selection bias) }\end{array}$ & Low risk & Random numbers table \\
\hline $\begin{array}{l}\text { Allocation concealment } \\
\text { (selection bias) }\end{array}$ & Unclear risk & Sealed envelopes \\
\hline $\begin{array}{l}\text { Blinding of participants } \\
\text { and personnel (perfor- } \\
\text { mance bias) }\end{array}$ & High risk & $\begin{array}{l}\text { Blinding not feasible. Likely that lack of blinding introduced bias, but unclear } \\
\text { All outcomes }\end{array}$ \\
\hline
\end{tabular}




\section{O'Keeffe 1996 (Continued)}

Blinding of outcome assessment (detection bias)

Data on these outcomes were not reported enteral route insertion

\begin{tabular}{|c|c|c|}
\hline $\begin{array}{l}\text { Blinding of outcome as- } \\
\text { sessment (detection bias) } \\
\text { Clinical outcomes }\end{array}$ & Unclear risk & Data on these outcomes were not reported \\
\hline $\begin{array}{l}\text { Blinding of outcome as- } \\
\text { sessment (detection bias) } \\
\text { Subjective outcomes }\end{array}$ & High risk & $\begin{array}{l}\text { Likely that lack of blinding biased the assessment of these outcomes; unclear } \\
\text { in which direction the results would have been biased }\end{array}$ \\
\hline $\begin{array}{l}\text { Incomplete outcome data } \\
\text { (attrition bias) } \\
\text { Outcomes related to par- } \\
\text { enteral route insertion }\end{array}$ & Unclear risk & Data on these outcomes were not reported \\
\hline $\begin{array}{l}\text { Incomplete outcome data } \\
\text { (attrition bias) } \\
\text { Clinical outcomes }\end{array}$ & High risk & $\begin{array}{l}2 \text { patients were excluded from the trial analyses ( } 1 \mathrm{IV} \text { patient was switched to } \\
\text { SC fluids and } 1 \text { patient in the SC group died). However, the mortality data were } \\
\text { included in the meta-analysis }\end{array}$ \\
\hline $\begin{array}{l}\text { Incomplete outcome data } \\
\text { (attrition bias) } \\
\text { Subjective outcomes }\end{array}$ & High risk & $\begin{array}{l}2 \text { patients were excluded from the trial analyses ( } 1 \text { IV patient was switched to } \\
\text { SC fluids and } 1 \text { patient in the SC group died) }\end{array}$ \\
\hline $\begin{array}{l}\text { Selective reporting (re- } \\
\text { porting bias) }\end{array}$ & Unclear risk & Insufficient information to permit judgement \\
\hline
\end{tabular}

\section{Reades 2011}

\begin{tabular}{ll}
\hline Methods & Parallel randomised trial \\
\hline Participants & Setting: pre-hospital setting in North Carolina, USA \\
182 adult patients with non-traumatic out-of-hospital cardiac arrest \\
- Intravenous group: $(n=67) ; M / F=42 / 25 ;$ mean age $(S D)=64.7(2.2)$ years \\
- Intraosseous group $1:(n=51) ; M / F=36 / 15 ;$ mean age $(S D)=61.2(2.4)$ years \\
- Intraosseous group $2:(n=64) ; M / F=41 / 23 ;$ mean age $(S D)=66.9(2.1)$ years
\end{tabular}

Interventions

- Intravenous group: inserted into any accessible peripheral vein but preferably at the antecubital fossa

- Intraosseous group 1: inserted into proximal humerus defined as the greater tubercle of the anterior humeral head $1 \mathrm{~cm}$ proximal to the surgical neck of humerus using $\mathrm{EZ}-1 \mathrm{O}^{\circledR}$

- Intraosseous group 2: inserted into the proximal tibia located medial to the tibial tuberosity, or just below the patella along the flat aspect of the tibia using EZ- $\mathrm{IO}^{\circledR}$

Data for intraosseous groups 1 and 2 were combined for the purpose of meta-analysis

Insertions performed by paramedics

Outcomes

Failure of route placement ${ }^{\wedge}$ ('first-attempt' success was defined for 10 insertion as secure placement of the catheter within the bone cavity and for IV insertion as secure placement within a peripheral vein. If initial access was not successful, the paramedics used their own judgement for choosing the subsequent site)

Time taken to secure access $\AA^{\wedge}$ 
Average number of insertion attempts $\ddagger^{\wedge}$

Dislodgements of access method ${ }^{\star \wedge}$

Paramedics' reported comfort with insertion method ${ }^{\star \wedge}$

Volume of fluid infused $\ddagger \wedge$

*not specified in trial registration record

$\ddagger$ mean and SD estimated from reported median and IQR for analysis - moderate sample size therefore SD calculated as $=$ range $/ 4$

$\wedge$ data analysed as intention-to-treat

\section{Risk of bias}

\begin{tabular}{lll}
\hline Bias & Authors' judgement & Support for judgement \\
\hline $\begin{array}{l}\text { Random sequence genera- } \\
\text { tion (selection bias) }\end{array}$ & Unclear risk & Not described \\
\hline $\begin{array}{l}\text { Allocation concealment } \\
\text { (selection bias) }\end{array}$ & High risk & $\begin{array}{l}300 \text { note cards were prepared in advance and labelled with a vascular access } \\
\text { method. Each note card was sealed in a blank, numbered envelope. Each crew } \\
\text { randomly selected and opened an envelope prior to every shift. The route se- } \\
\text { lected was applied to the crew's first cardiac arrest of the day }\end{array}$
\end{tabular}

\begin{tabular}{|c|c|c|}
\hline $\begin{array}{l}\text { Blinding of participants } \\
\text { and personnel (perfor- }\end{array}$ & High risk & $\begin{array}{l}\text { Blinding not feasible. Likely that lack of blinding introduced bias, but unclear } \\
\text { in which direction the results would have been biased }\end{array}$ \\
\hline
\end{tabular}
in which direction the results would have been biased

mance bias)

All outcomes

\begin{tabular}{lll}
\hline $\begin{array}{l}\text { Blinding of outcome as- } \\
\text { sessment (detection bias) } \\
\text { Outcomes related to par- } \\
\text { enteral route insertion }\end{array}$ & High risk & $\begin{array}{l}\text { Likely that lack of blinding biased the assessment of these outcomes; unclear } \\
\text { in which direction the results would have been biased }\end{array}$ \\
\hline $\begin{array}{l}\text { Blinding of outcome as- } \\
\text { sessment (detection bias) } \\
\text { Clinical outcomes }\end{array}$ & Unclear risk & Data on these outcomes were not reported \\
\hline $\begin{array}{l}\text { Blinding of outcome as- } \\
\text { sessment (detection bias) }\end{array}$ & High risk & $\begin{array}{l}\text { Likely that lack of blinding biased the assessment of these outcomes; unclear } \\
\text { in which direction the results would have been biased }\end{array}$ \\
\hline $\begin{array}{l}\text { Incomplete outcome data } \\
\text { (attrition bias) } \begin{array}{l}\text { Outcomes related to par- } \\
\text { enteral route insertion }\end{array}\end{array}$ & Low risk & $\begin{array}{l}\text { The allocated method was not used in } 13 \text { patients due to "human error or sit- } \\
\text { uations beyond the control of the paramedic" (9 in the humeral IO group and } \\
\text { in the IV group). Success of insertion data was analysed on both an inten- } \\
\text { tion-to-treat and as-treated basis. Other outcomes were analysed as inten- } \\
\text { tion-to-treat }\end{array}$ \\
\hline
\end{tabular}

\begin{tabular}{lll}
\hline $\begin{array}{l}\text { Incomplete outcome data } \\
\text { (attrition bias) }\end{array}$ & Low risk & Analysed as intention-to-treat \\
Clinical outcomes & \\
\hline $\begin{array}{l}\text { Incomplete outcome data } \\
\text { (attrition bias) }\end{array}$ & Low risk & Analysed as intention-to-treat \\
Subjective outcomes & &
\end{tabular}


Reades 2011 (Continued)

Selective reporting (re- High risk Prospectively registered (NCT01119807). Additional secondary outcomes were porting bias) reported in the final report that were not mentioned in the registration record

Selam 1983

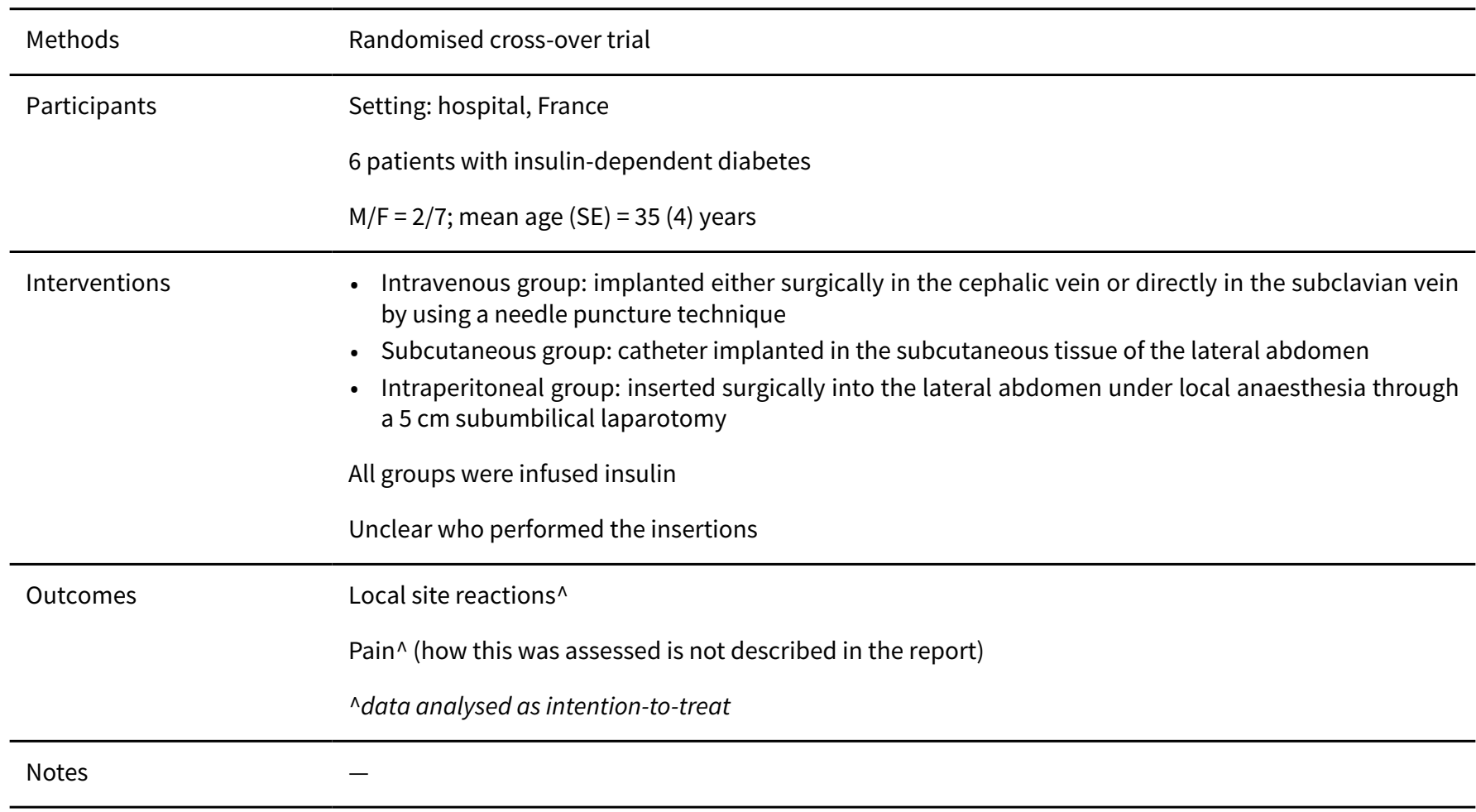

\section{Risk of bias}

Bias Authors' judgement Support for judgement

$\begin{aligned} & \text { Random sequence genera- } \\ & \text { tion (selection bias) }\end{aligned}$
Unclear risk $\quad$ Not described

\begin{tabular}{|c|c|c|}
\hline $\begin{array}{l}\text { Allocation concealment } \\
\text { (selection bias) }\end{array}$ & Unclear risk & Not described \\
\hline $\begin{array}{l}\text { Blinding of participants } \\
\text { and personnel (perfor- } \\
\text { mance bias) } \\
\text { All outcomes }\end{array}$ & High risk & $\begin{array}{l}\text { Blinding not feasible. Likely that lack of blinding introduced bias, but unclear } \\
\text { in which direction the results would have been biased }\end{array}$ \\
\hline $\begin{array}{l}\text { Blinding of outcome as- } \\
\text { sessment (detection bias) } \\
\text { Outcomes related to par- } \\
\text { enteral route insertion }\end{array}$ & Unclear risk & Data on these outcomes were not reported \\
\hline
\end{tabular}

\begin{tabular}{lll}
\hline $\begin{array}{l}\text { Blinding of outcome as- } \\
\text { sessment (detection bias) } \\
\text { Clinical outcomes }\end{array}$ & Unclear risk & Not applicable (trial does not involve fluid administration) \\
\hline $\begin{array}{l}\text { Blinding of outcome as- } \\
\text { sessment (detection bias) }\end{array}$ & High risk & $\begin{array}{l}\text { Likely that lack of blinding biased the assessment of these outcomes; unclear } \\
\text { in which direction the effect estimate may have been biased }\end{array}$ \\
\hline
\end{tabular}


Selam 1983 (Continued)

Subjective outcomes

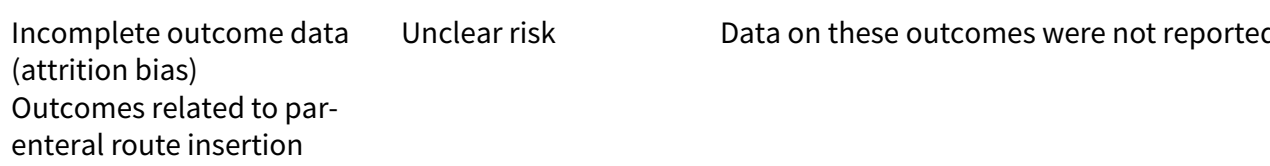

Incomplete outcome data Unclear risk Data on these outcomes were not reported
(attrition bias)

Clinical outcomes

\begin{tabular}{l}
\hline Incomplete outcome data Low risk No exclusions \\
(attrition bias) \\
Subjective outcomes
\end{tabular}

Selective reporting (re- Unclear risk Insufficient information to permit judgement
porting bias)

\section{Slesak 2003}

\begin{tabular}{ll}
\hline Methods & Parallel randomised trial \\
\hline Participants & Setting: hospital geriatric department, Germany \\
& 96 hospitalised patients aged 60 years and over with mild to moderate dehydration \\
& - Intravenous group: $(n=48) ; M / F=12 / 36 ;$ mean age $(S D)=85.3(5.8)$ years \\
- Subcutaneous group: $(n=14) ; M / F=17 / 31 ;$ mean age $(S D)=85.3(7.6)$ years
\end{tabular}

Interventions - Intravenous group: 18 to $22 \mathrm{G}$ peripheral catheters

- Subcutaneous group: $21 \mathrm{G}$ butterfly into thigh, abdomen or thorax

Both groups infused with half-normal saline-glucose solutions for as long as clinically necessary

Insertions performed by nurses and doctors

Outcomes

Time to infusiona^

Time with functional accessa^ $\wedge$

Local site reactions (oedema, erythema, cellulitis, phlebitis, pain)^

Doctors and nurses feasibility of route scores $\ddagger^{\wedge}$ ('feasibility' described in the trial report as "with regard to the practical implementation and the occurrence of complications")

Patient discomfort $\AA^{\wedge}$ (measured using a Likert-like scale, points ranging from $1=$ very good to $6=$ very bad)

Volume of fluid infuseda^

Serum sodium^ ${ }^{\wedge}$

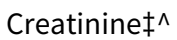

$\ddagger$ mean and SD estimated from reported median and IQR for analysis - moderate sample size therefore SD calculated as $=$ range $/ 4$

amean and SD estimated from reported median and minimum-maximum values for analysis - moderate sample size therefore SD calculated as $=$ range $/ 4$ 
Slesak 2003 (Continued)

$\wedge$ data analysed as intention-to-treat

Notes -

\section{Risk of bias}

\begin{tabular}{lll}
\hline Bias & Authors' judgement & Support for judgement \\
\hline $\begin{array}{l}\text { Random sequence genera- } \\
\text { tion (selection bias) }\end{array}$ & Unclear risk & Not described \\
\hline $\begin{array}{l}\text { Allocation concealment } \\
\text { (selection bias) }\end{array}$ & Unclear risk & Shuffled blocks of 6 sealed envelopes, each containing 3 of each treatment \\
\hline $\begin{array}{l}\text { Blinding of participants } \\
\text { and personnel (perfor- } \\
\text { mance bias) }\end{array}$ & High risk & $\begin{array}{l}\text { Blinding not feasible. Likely that lack of blinding introduced bias, but unclear } \\
\text { ill outcomes }\end{array}$ \\
\hline
\end{tabular}

\begin{tabular}{lll}
\hline Blinding of outcome as- & High risk & Likely that lack of blinding biased the assessment of these outcomes; unclear \\
sessment (detection bias) & in which direction the results would have been biased
\end{tabular}

Outcomes related to par-

enteral route insertion

\begin{tabular}{|c|c|c|}
\hline $\begin{array}{l}\text { Blinding of outcome as- } \\
\text { sessment (detection bias) }\end{array}$ & Low risk & $\begin{array}{l}\text { We judge that measurement of these outcomes is not likely to be influenced by } \\
\text { lack of blinding }\end{array}$ \\
\hline
\end{tabular}

\begin{tabular}{|c|c|c|}
\hline $\begin{array}{l}\text { Blinding of outcome as- } \\
\text { sessment (detection bias) } \\
\text { Subjective outcomes }\end{array}$ & High risk & $\begin{array}{l}\text { Likely that lack of blinding biased the assessment of these outcomes; unclear } \\
\text { in which direction the results would have been biased }\end{array}$ \\
\hline
\end{tabular}

\begin{tabular}{|c|c|c|}
\hline $\begin{array}{l}\text { Incomplete outcome data } \\
\text { (attrition bias) } \\
\text { Outcomes related to par- } \\
\text { enteral route insertion }\end{array}$ & Low risk & $\begin{array}{l}\text { No exclusions reported. However, } 13 \text { patients in the SC group were switched } \\
\text { to IV and } 17 \text { patients in the IV group were switched to SC. Data were analysed } \\
\text { according to intention-to-treat }\end{array}$ \\
\hline $\begin{array}{l}\text { Incomplete outcome data } \\
\text { (attrition bias) } \\
\text { Clinical outcomes }\end{array}$ & Low risk & $\begin{array}{l}\text { No exclusions reported. However, } 13 \text { patients in the SC group were switched } \\
\text { to IV and } 17 \text { patients in the IV group were switched to SC. Data were analysed } \\
\text { according to intention-to-treat }\end{array}$ \\
\hline $\begin{array}{l}\text { Incomplete outcome data } \\
\text { (attrition bias) } \\
\text { Subjective outcomes }\end{array}$ & Low risk & $\begin{array}{l}\text { No exclusions reported. However, } 13 \text { patients in the SC group were switched } \\
\text { to IV and } 17 \text { patients in the IV group were switched to SC. Data were analysed } \\
\text { according to intention-to-treat }\end{array}$ \\
\hline $\begin{array}{l}\text { Selective reporting (re- } \\
\text { porting bias) }\end{array}$ & Unclear risk & Insufficient information to permit judgement \\
\hline
\end{tabular}

\section{Spandorfer 2005}

\begin{tabular}{ll}
\hline Methods & Parallel randomised trial \\
\hline Participants & Setting: 24 hospitals, USA \\
& 148 children with mild to moderate dehydration aged 1 month to $<10$ years \\
& Intravenous group: $(n=75) ; M / F=39 / 36 ;$ mean age (range $)=2.4(2.07)$ years \\
\hline
\end{tabular}


Spandorfer 2005 (Continued)

- Subcutaneous group: $(n=73) ; M / F=34 / 39$; mean age $($ range $)=2.1(1.72)$ years

\begin{tabular}{ll}
\hline Interventions & Intravenous group: details of route not described \\
- Subcutaneous group: details of route not described. Hyaluronidase used in all patients & $20 \mathrm{ml} / \mathrm{kg}$ isotonic fluids over 1 hour \\
Insertions performed by "health care providers" & Failure of route placement ${ }^{\wedge}$ (definition of failure not specified in the report) \\
& Time to infusion ${ }^{\wedge}$ \\
Outcomes & Local site reactions (erythema, oedema, swelling)^ \\
& Clinicians' perception of ease of route to perform ${ }^{\wedge}$ \\
& Patient discomfort^ (assessed using the FLACC scale for those <3 years or FACES Pain Rating scale for \\
those $\geq 3$ years) \\
Volume of fluid infused ${ }^{\wedge}$ \\
^data analysed as intention-to-treat
\end{tabular}

Notes -

\section{Risk of bias}

\begin{tabular}{lll}
\hline Bias & Authors' judgement & Support for judgement \\
\hline $\begin{array}{l}\text { Random sequence genera- } \\
\text { tion (selection bias) }\end{array}$ & Low risk & Computer-generated randomisation \\
\hline $\begin{array}{l}\text { Allocation concealment } \\
\text { (selection bias) }\end{array}$ & Low risk & Central randomisation \\
\hline $\begin{array}{l}\text { Blinding of participants } \\
\text { and personnel (perfor- } \\
\text { mance bias) }\end{array}$ & High risk & $\begin{array}{l}\text { Blinding not feasible. Likely that lack of blinding introduced bias, but unclear } \\
\text { ill outcomes which direction the results would have been biased }\end{array}$ \\
\hline
\end{tabular}

\begin{tabular}{|c|c|c|}
\hline $\begin{array}{l}\text { Blinding of outcome as- } \\
\text { sessment (detection bias) } \\
\text { Outcomes related to par- } \\
\text { enteral route insertion }\end{array}$ & High risk & $\begin{array}{l}\text { Likely that lack of blinding biased the assessment of these outcomes; unclear } \\
\text { in which direction the results would have been biased }\end{array}$ \\
\hline
\end{tabular}

\begin{tabular}{ll}
\hline Blinding of outcome as- & Unclear risk \\
sessment (detection bias) & \\
Clinical outcomes & \\
\hline
\end{tabular}

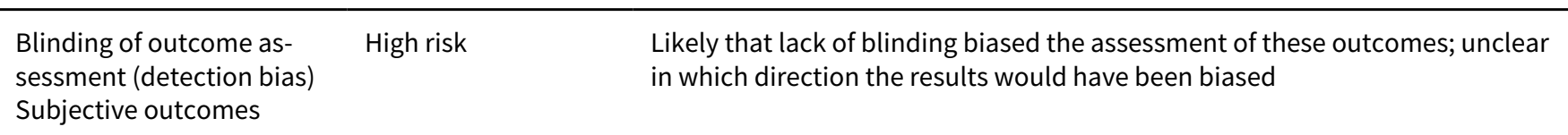

\begin{tabular}{|c|c|c|}
\hline $\begin{array}{l}\text { Incomplete outcome data } \\
\text { (attrition bias) } \\
\text { Outcomes related to par- } \\
\text { enteral route insertion }\end{array}$ & Low risk & $\begin{array}{l}1 \text { patient in the IV group was excluded from the trial at the request of the par- } \\
\text { ent. } 15 \text { patients in the IV group were switched to SC. Both intention-to-treat } \\
\text { and as-treated data are presented }\end{array}$ \\
\hline $\begin{array}{l}\text { Incomplete outcome data } \\
\text { (attrition bias) }\end{array}$ & Unclear risk & Data on these outcomes were not reported \\
\hline
\end{tabular}


Spandorfer 2005 (Continued)

Clinical outcomes

$\begin{aligned} & \text { Incomplete outcome data Low risk } \\ & \begin{array}{l}\text { (attrition bias) } \\ \text { Subjective outcomes }\end{array}\end{aligned} \begin{aligned} & 1 \text { patient in the IV group was excluded from the trial at the request of the par- } \\ & \text { ent. } 15 \text { patients in the IV group were switched to SC. Both intention-to-treat } \\ & \text { and as-treated data are presented }\end{aligned}$

Selective reporting (re- Unclear risk Insufficient information to permit judgement

porting bias)

CBRN: chemical, biological, radiological and nuclear (protective equipment)

$\mathrm{Cl}$ : confidence interval

$F$ : female

FLACC scale: Face, Legs, Activity, Cry, Consolability scale

IO: intraosseous

IP: intraperitoneal

IQR: interquartile range

IV: intravenous

M: male

$\mathrm{NaCl}$ : sodium chloride

NR: not reported

SC: subcutaneous

SD: standard deviation

SE: standard error

SEM: standard error of the mean

Characteristics of excluded studies [ordered by study ID]

\begin{tabular}{ll}
\hline Study & Reason for exclusion \\
\hline Chavez-Negrete 1991 & $\begin{array}{l}\text { Trial in which patients were randomised to receive an infusion of } 7.5 \% \mathrm{NaCl}+6 \% \text { dextran } 60 \text { or } \\
\text { Ringer's lactate. Within each arm some of the patients received the assigned fluids intravenous- } \\
\text { ly and others intraosseously. However, the parenteral method for infusion was not determined at } \\
\text { random, so the trial was not eligible for inclusion in this review }\end{array}$ \\
\hline
\end{tabular}

\begin{tabular}{ll}
\hline Ismael 2012 & The parenteral methods under study were not used for infusion of fluids or medication \\
\hline Klemenz 1997 & $\begin{array}{l}\text { Not a RCT; the article is a letter describing the subcutaneous and intravenous methods for deliver- } \\
\text { ing fluids }\end{array}$ \\
\hline Koshy 2005 & $\begin{array}{l}\text { Not relevant to the review question; the purpose of the trial was to assess the effects of the infusion } \\
\text { of analgesia on cancer pain }\end{array}$ \\
\hline Lee 2009 & $\begin{array}{l}\text { The parenteral methods under study were not used for infusion of fluids or medication } \\
\text { Mace } 2013\end{array}$ \\
\hline $\begin{array}{l}\text { Not a RCT. The study evaluated the cost-effectiveness of subcutaneous fluid adminsitration com- } \\
\text { pared to intravenous fluid administration in children with mild to moderate dehydration }\end{array}$ \\
\hline $\begin{array}{l}\text { Not a RCT. The study explores the effect of intraperitoneal routes in dehydrated patients. All pa- } \\
\text { tients received fluids via both the intravenous and intraperitoneal routes }\end{array}$ \\
\hline $\begin{array}{l}\text { Not relevant to the review question; the purpose of the trial was to assess the effects of the infusion } \\
\text { of analgesia on cancer pain }\end{array}$ \\
\hline $\begin{array}{l}\text { Cross-over study comparing intravenous and subcutaneous morphine. However, the order in } \\
\text { which the patients received the methods was not randomised - all received intravenous morphine } \\
\text { followed by subcutaneous morphine }\end{array}$
\end{tabular}




\begin{tabular}{|c|c|}
\hline Study & Reason for exclusion \\
\hline Paxton 2009 & Not a RCT. This is a prospective cohort study exploring intraosseous and intravenous access \\
\hline Rajani 2011 & $\begin{array}{l}\text { Comparison of umbilical venous access versus intraosseous access under simulated conditions. } \\
\text { Umbilical venous access was not an eligible type of intervention }\end{array}$ \\
\hline Ransome-Kuti 1969 & $\begin{array}{l}\text { Not a RCT. This is a case series report describing the outcomes of } 91 \text { dehydrated babies who were } \\
\text { administered fluids via the intraperitoneal route }\end{array}$ \\
\hline Robinson 1993 & The parenteral methods under study were not used for infusion of fluids or medication \\
\hline Soremekun 2009 & $\begin{array}{l}\text { Cross-over study comparing intravenous and subcutaneous glucose. However, the order in which } \\
\text { the patients received the methods was not randomised - all received intravenous access first fol- } \\
\text { lowed by subcutaneous access }\end{array}$ \\
\hline Tighe 1993 & $\begin{array}{l}\text { Not a RCT. This is a case series report describing the outcomes of } 9 \text { dehydrated children who were } \\
\text { administered fluids via the intravenous, intraosseous or intraperitoneal route. The route received } \\
\text { was not allocated at random }\end{array}$ \\
\hline
\end{tabular}

$\mathrm{NaCl}$ : sodium chloride

RCT: randomised controlled trial

DATA AND ANALYSES

\section{Comparison 1. Intravenous versus intraosseous access}

\begin{tabular}{lllll}
\hline Outcome or subgroup title & No. of studies & $\begin{array}{l}\text { No. of partici- } \\
\text { pants }\end{array}$ & Statistical method & Effect size \\
\hline 1 Insertion failures & 2 & 242 & Risk Ratio (M-H, Fixed, 95\% Cl) & $3.89[2.39,6.33]$ \\
\hline $\begin{array}{l}2 \text { Insertion failures (sub- } \\
\text { group analysis child vs } \\
\text { adult) }\end{array}$ & 2 & 242 & Risk Ratio (M-H, Fixed, 95\% Cl) & $3.89[2.39,6.33]$ \\
\hline $\begin{array}{l}2.1 \text { Adult } \\
2.2 \text { Child }\end{array}$ & 1 & Risk Ratio (M-H, Fixed, 95\% Cl) & $3.24[2.00,5.27]$ \\
\hline $\begin{array}{l}\text { Time to infusion/place- } \\
\text { ment }\end{array}$ & 4 & Risk Ratio (M-H, Fixed, 95\% Cl) & $21.0[1.29,342.93]$ \\
\hline $\begin{array}{l}4 \text { Average number of inser- } \\
\text { tion attempts }\end{array}$ & 1 & Mean Difference (Fixed, 95\% Cl) & Totals not selected \\
\hline $\begin{array}{l}5 \text { Dislodgement of device } \\
\text { during infusion }\end{array}$ & 1 & 60 & Mean Difference (IV, Fixed, 95\% Cl) & Totals not selected \\
\hline $\begin{array}{l}6 \text { Local site reactions } \\
\begin{array}{l}6.1 \text { Infection } \\
\hline\end{array}\end{array}$ & 1 & Risk Ratio (M-H, Fixed, 95\% Cl) & Totals not selected \\
\hline
\end{tabular}




\begin{tabular}{|c|c|c|c|c|}
\hline Outcome or subgroup title & No. of studies & $\begin{array}{l}\text { No. of partici- } \\
\text { pants }\end{array}$ & Statistical method & Effect size \\
\hline $\begin{array}{l}7 \text { Clinician's perception of } \\
\text { ease/feasibility of adminis- } \\
\text { tration }\end{array}$ & 1 & & Risk Ratio (M-H, Fixed, 95\% Cl) & Totals not selected \\
\hline $\begin{array}{l}8 \text { Volume of fluids trans- } \\
\text { fused }\end{array}$ & 1 & & Mean Difference (IV, Fixed, 95\% CI) & Totals not selected \\
\hline 9 Electrolyte level & 1 & & Mean Difference (IV, Fixed, 95\% CI) & Totals not selected \\
\hline 9.1 Sodium & 1 & & Mean Difference (IV, Fixed, 95\% CI) & $0.0[0.0,0.0]$ \\
\hline 9.2 Potassium & 1 & & Mean Difference (IV, Fixed, 95\% CI) & $0.0[0.0,0.0]$ \\
\hline 10 Renal function & 1 & & Mean Difference (IV, Fixed, 95\% CI) & Totals not selected \\
\hline 10.1 Urea & 1 & & Mean Difference (IV, Fixed, 95\% CI) & $0.0[0.0,0.0]$ \\
\hline 10.2 Creatinine & 1 & & Mean Difference (IV, Fixed, 95\% CI) & $0.0[0.0,0.0]$ \\
\hline
\end{tabular}

Analysis 1.1. Comparison 1 Intravenous versus intraosseous access, Outcome 1 Insertion failures.

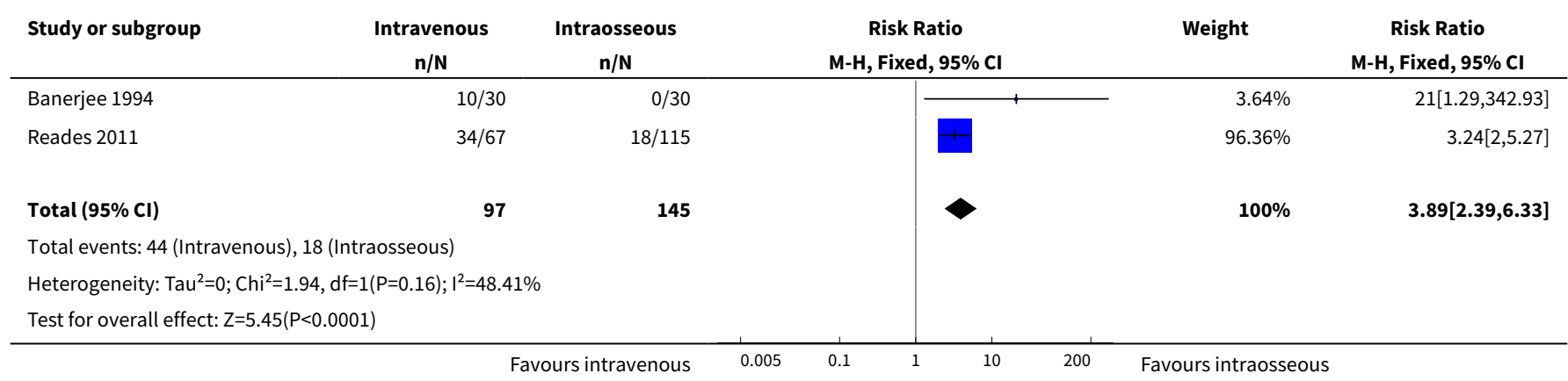

\section{Analysis 1.2. Comparison 1 Intravenous versus intraosseous access, Outcome 2 Insertion failures (subgroup analysis child vs adult).}

\begin{tabular}{|c|c|c|c|c|c|}
\hline Study or subgroup & $\begin{array}{c}\text { Intravenous } \\
n / N\end{array}$ & $\begin{array}{c}\text { Intraosseous } \\
n / N\end{array}$ & $\begin{array}{c}\text { Risk Ratio } \\
\text { M-H, Fixed, 95\% Cl }\end{array}$ & Weight & $\begin{array}{c}\text { Risk Ratio } \\
\text { M-H, Fixed, } 95 \% \mathrm{Cl}\end{array}$ \\
\hline \multicolumn{6}{|l|}{ 1.2.1 Adult } \\
\hline Reades 2011 & $34 / 67$ & $18 / 115$ & & $96.36 \%$ & $3.24[2,5.27]$ \\
\hline Subtotal $(95 \% \mathrm{Cl})$ & 67 & 115 & & $96.36 \%$ & $3.24[2,5.27]$ \\
\hline \multicolumn{6}{|c|}{ Total events: 34 (Intravenous), 18 (Intraosseous) } \\
\hline \multicolumn{6}{|c|}{ Heterogeneity: Not applicable } \\
\hline \multicolumn{6}{|c|}{ Test for overall effect: $Z=4.75(P<0.0001)$} \\
\hline \multicolumn{6}{|l|}{ 1.2.2 Child } \\
\hline Banerjee 1994 & $10 / 30$ & $0 / 30$ & 1 & $3.64 \%$ & $21[1.29,342.93]$ \\
\hline Subtotal $(95 \% \mathrm{Cl})$ & 30 & 30 & 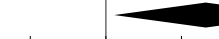 & $3.64 \%$ & $21[1.29,342.93]$ \\
\hline
\end{tabular}




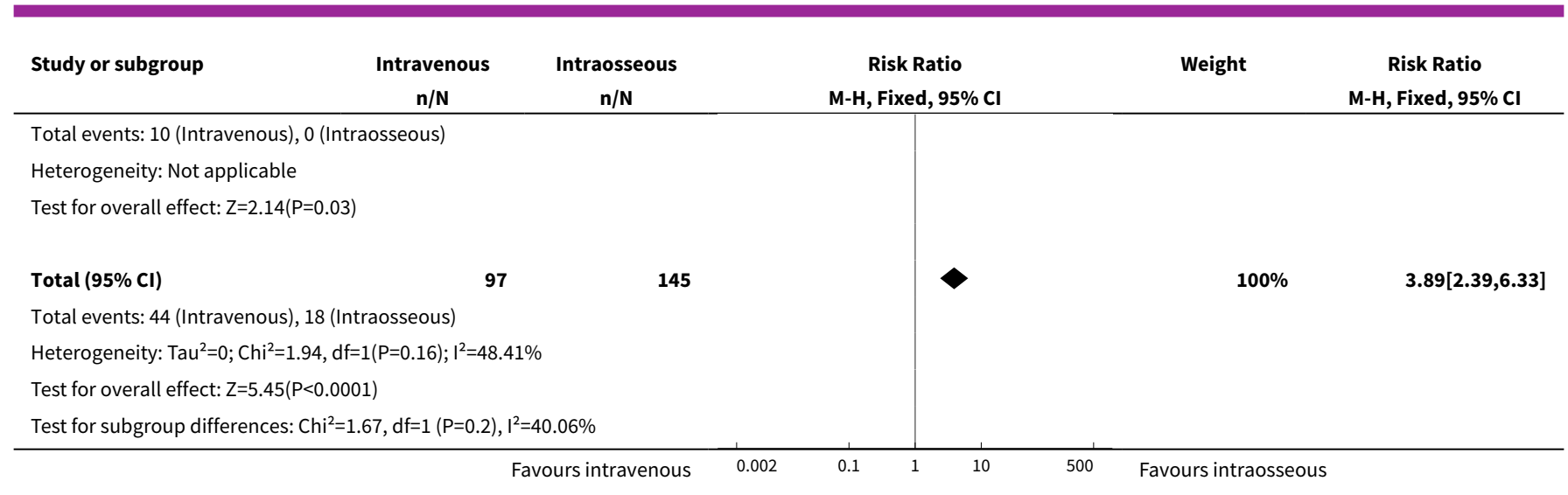

\section{Analysis 1.3. Comparison 1 Intravenous versus intraosseous access, Outcome 3 Time to infusion/placement.}

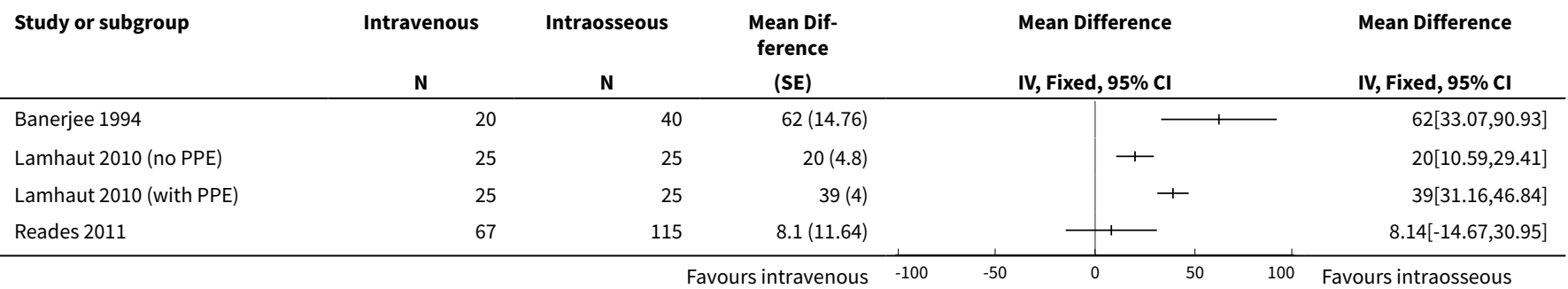

\section{Analysis 1.4. Comparison 1 Intravenous versus intraosseous access, Outcome 4 Average number of insertion attempts.}

\begin{tabular}{|c|c|c|c|c|c|c|}
\hline \multirow[t]{2}{*}{ Study or subgroup } & \multicolumn{2}{|c|}{ Intravenous } & \multicolumn{2}{|c|}{ Intraosseous } & \multirow{2}{*}{$\begin{array}{c}\text { Mean Difference } \\
\text { Fixed, } 95 \% \mathrm{Cl}\end{array}$} & \multirow{2}{*}{$\begin{array}{c}\text { Mean Difference } \\
\text { Fixed, } 95 \% \mathrm{Cl}\end{array}$} \\
\hline & $\mathbf{N}$ & $\operatorname{Mean}(S D)$ & $\mathbf{N}$ & $\operatorname{Mean}(S D)$ & & \\
\hline Reades 2011 & 67 & $1(0.3)$ & 115 & $1(0.2)$ & + & $0[-0.07,0.07]$ \\
\hline
\end{tabular}

\section{Analysis 1.5. Comparison 1 Intravenous versus intraosseous access, Outcome 5 Dislodgement of device during infusion.}

\begin{tabular}{|c|c|c|c|c|}
\hline Study or subgroup & $\begin{array}{c}\text { Intravenous } \\
n / \mathbf{N}\end{array}$ & $\begin{array}{c}\text { Intraosseous } \\
n / N\end{array}$ & $\begin{array}{c}\text { Risk Ratio } \\
\text { M-H, Fixed, 95\% Cl }\end{array}$ & $\begin{array}{c}\text { Risk Ratio } \\
\text { M-H, Fixed, 95\% CI }\end{array}$ \\
\hline Reades 2011 & $4 / 67$ & $13 / 115$ & \begin{tabular}{l|l}
1 & \\
\end{tabular} & $0.53[0.18,1.55]$ \\
\hline
\end{tabular}


Analysis 1.6. Comparison 1 Intravenous versus intraosseous access, Outcome 6 Local site reactions.

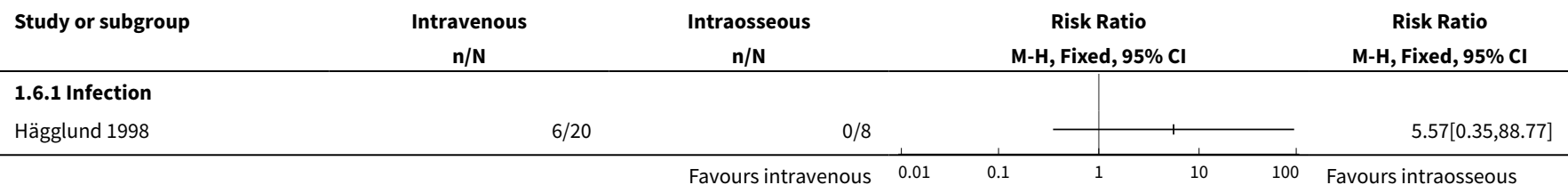

Analysis 1.7. Comparison 1 Intravenous versus intraosseous access, Outcome 7 Clinician's perception of ease/feasibility of administration.

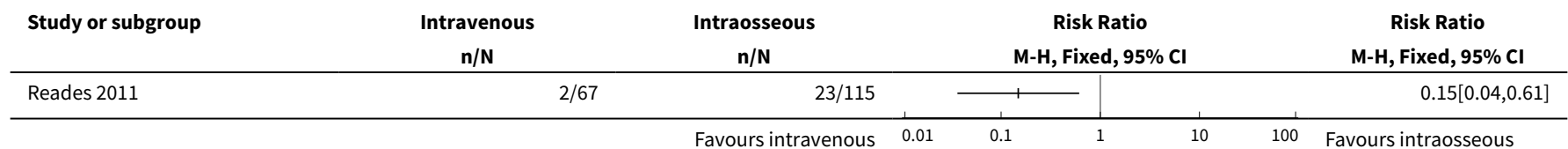

Analysis 1.8. Comparison 1 Intravenous versus intraosseous access, Outcome 8 Volume of fluids transfused.

\begin{tabular}{|c|c|c|c|c|c|c|c|c|c|}
\hline \multirow{3}{*}{$\begin{array}{l}\text { Study or subgroup } \\
\text { Reades } 2011\end{array}$} & \multicolumn{2}{|c|}{ Intravenous } & \multicolumn{2}{|c|}{ Intraosseous } & \multirow{2}{*}{\multicolumn{4}{|c|}{$\begin{array}{c}\text { Mean Difference } \\
\text { Fixed, } 95 \% \mathrm{Cl}\end{array}$}} & \multirow{3}{*}{$\begin{array}{l}\text { Mean Difference } \\
\text { Fixed, 95\% Cl } \\
400[365.57,434.43\end{array}$} \\
\hline & \multirow{2}{*}{$\frac{\mathbf{N}}{67}$} & \multirow{2}{*}{$\frac{\text { Mean(SD) }}{800(125)}$} & \multirow{2}{*}{$\frac{\mathbf{N}}{115}$} & \multirow{2}{*}{$\frac{\text { Mean(SD) }}{400(93.1)}$} & & & & & \\
\hline & & & & & & & & + & \\
\hline
\end{tabular}

Analysis 1.9. Comparison 1 Intravenous versus intraosseous access, Outcome 9 Electrolyte level.

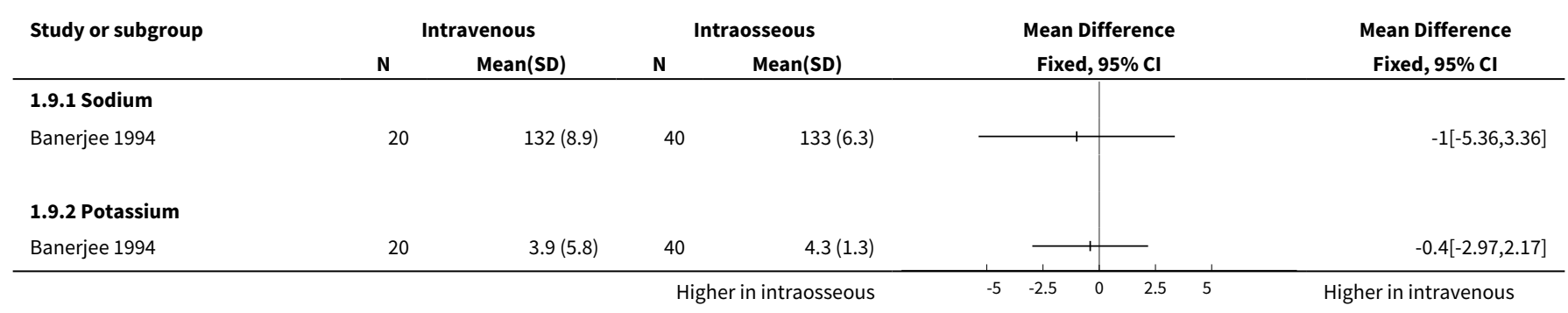

Analysis 1.10. Comparison 1 Intravenous versus intraosseous access, Outcome 10 Renal function.

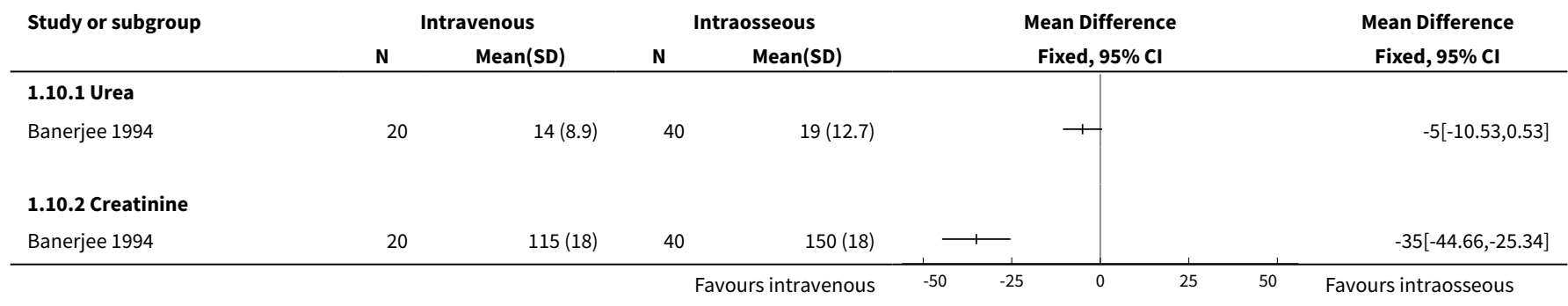


Comparison 2. Intravenous versus subcutaneous access

\begin{tabular}{|c|c|c|c|c|}
\hline Outcome or subgroup title & No. of studies & $\begin{array}{l}\text { No. of partici- } \\
\text { pants }\end{array}$ & Statistical method & Effect size \\
\hline 1 Insertion failures & 3 & 238 & Risk Ratio (M-H, Fixed, 95\% Cl) & $14.79[2.87,76.08]$ \\
\hline $\begin{array}{l}2 \text { Insertion failures (sensitiv- } \\
\text { ity analysis - trial(s) with ad- } \\
\text { equate allocation conceal- } \\
\text { ment) }\end{array}$ & 1 & & Risk Ratio (M-H, Fixed, 95\% Cl) & Totals not selected \\
\hline $\begin{array}{l}3 \text { Insertion failures (subgroup } \\
\text { analysis child vs adult) }\end{array}$ & 3 & 238 & Risk Ratio (M-H, Fixed, 95\% Cl) & $14.79[2.87,76.08]$ \\
\hline 3.1 Adult & 2 & 90 & Risk Ratio (M-H, Fixed, 95\% Cl) & $6.0[0.76,47.39]$ \\
\hline 3.2 Child & 1 & 148 & Risk Ratio (M-H, Fixed, 95\% Cl) & $32.13[1.96,525.87]$ \\
\hline 4 Time to infusion/placement & 1 & & Mean Difference (IV, Fixed, 95\% CI) & Totals not selected \\
\hline $\begin{array}{l}5 \text { Dislodgement of device } \\
\text { during infusion }\end{array}$ & 1 & & Risk Ratio (M-H, Fixed, 95\% Cl) & Totals not selected \\
\hline $\begin{array}{l}6 \text { Time with functional access } \\
\text { (days) }\end{array}$ & 1 & & Mean Difference (IV, Fixed, 95\% CI) & Totals not selected \\
\hline 7 Local site reactions & 9 & & Risk Ratio (M-H, Fixed, 95\% Cl) & Subtotals only \\
\hline 7.1 Any & 5 & 247 & Risk Ratio (M-H, Fixed, 95\% Cl) & $0.91[0.80,1.02]$ \\
\hline 7.2 Erythema & 4 & 296 & Risk Ratio (M-H, Fixed, 95\% Cl) & $0.43[0.31,0.61]$ \\
\hline 7.3 Swelling & 1 & 148 & Risk Ratio (M-H, Fixed, 95\% Cl) & $0.26[0.17,0.41]$ \\
\hline 7.4 Infection & 4 & 211 & Risk Ratio (M-H, Fixed, 95\% Cl) & $3.70[1.06,12.88]$ \\
\hline 7.5 Phlebitis & 3 & 181 & Risk Ratio (M-H, Fixed, 95\% Cl) & $5.04[1.14,22.30]$ \\
\hline 7.6 Oedema & 7 & 453 & Risk Ratio (M-H, Fixed, 95\% Cl) & $0.42[0.25,0.72]$ \\
\hline $\begin{array}{l}8 \text { Local site reactions (sensi- } \\
\text { tivity analysis - trial(s) with } \\
\text { adequate allocation conceal- } \\
\text { ment) }\end{array}$ & 3 & & Risk Ratio (M-H, Fixed, 95\% Cl) & Subtotals only \\
\hline 8.1 Any & 3 & 202 & Risk Ratio (M-H, Fixed, 95\% Cl) & $0.87[0.79,0.96]$ \\
\hline 8.2 Erythema & 3 & 200 & Risk Ratio (M-H, Fixed, 95\% Cl) & $0.33[0.22,0.49]$ \\
\hline 8.3 Swelling & 1 & 148 & Risk Ratio (M-H, Fixed, 95\% Cl) & $0.26[0.17,0.41]$ \\
\hline 8.4 Infection & 1 & 18 & Risk Ratio (M-H, Fixed, 95\% Cl) & $3.0[0.14,65.16]$ \\
\hline 8.5 Phlebitis & 1 & 18 & Risk Ratio (M-H, Fixed, 95\% Cl) & $3.0[0.14,65.16]$ \\
\hline
\end{tabular}




\begin{tabular}{|c|c|c|c|c|}
\hline Outcome or subgroup title & No. of studies & $\begin{array}{l}\text { No. of partici- } \\
\text { pants }\end{array}$ & Statistical method & Effect size \\
\hline 8.6 Oedema & 3 & 202 & Risk Ratio (M-H, Fixed, 95\% Cl) & $0.25[0.06,1.15]$ \\
\hline $\begin{array}{l}9 \text { Clinicians' scores of feasi- } \\
\text { bility of insertion }\end{array}$ & 1 & & Mean Difference (IV, Fixed, 95\% CI) & Totals not selected \\
\hline 9.1 Doctors' scores & 1 & & Mean Difference (IV, Fixed, 95\% CI) & $0.0[0.0,0.0]$ \\
\hline 9.2 Nurses' scores & 1 & & Mean Difference (IV, Fixed, 95\% Cl) & $0.0[0.0,0.0]$ \\
\hline $\begin{array}{l}10 \text { Clinician's perception of } \\
\text { difficulty of insertion }\end{array}$ & 1 & & Risk Ratio (M-H, Fixed, 95\% Cl) & Totals not selected \\
\hline 11 Patients' discomfort & 5 & & Risk Ratio (M-H, Fixed, 95\% Cl) & Subtotals only \\
\hline 11.1 Pain & 3 & 262 & Risk Ratio (M-H, Fixed, 95\% Cl) & $1.01[0.83,1.22]$ \\
\hline 11.2 Agitation & 2 & 125 & Risk Ratio (M-H, Fixed, 95\% Cl) & $1.84[1.26,2.70]$ \\
\hline $\begin{array}{l}12 \text { Patients' discomfort (sen- } \\
\text { sitivity analysis - trial(s) with } \\
\text { adequate allocation conceal- } \\
\text { ment) }\end{array}$ & 2 & & Risk Ratio (M-H, Fixed, 95\% Cl) & Subtotals only \\
\hline 12.1 Pain & 2 & 166 & Risk Ratio (M-H, Fixed, 95\% Cl) & $0.97[0.81,1.16]$ \\
\hline 13 Patient discomfort score & 1 & & Mean Difference (IV, Fixed, 95\% CI) & Totals not selected \\
\hline 14 Mortality & 2 & 106 & Risk Ratio (M-H, Fixed, 95\% Cl) & $1.04[0.18,5.92]$ \\
\hline $\begin{array}{l}15 \text { Mortality (sensitivity } \\
\text { analysis - trial(s) with ade- } \\
\text { quate allocation conceal- } \\
\text { ment) }\end{array}$ & 1 & & Risk Ratio (M-H, Fixed, 95\% Cl) & Totals not selected \\
\hline $\begin{array}{l}16 \text { Volume of fluids trans- } \\
\text { fused }\end{array}$ & 4 & & Mean Difference (IV, Fixed, 95\% CI) & Totals not selected \\
\hline $\begin{array}{l}17 \text { Volume of fluids trans- } \\
\text { fused (sensitivity analysis - } \\
\text { trial(s) with adequate alloca- } \\
\text { tion) }\end{array}$ & 1 & & Mean Difference (IV, Fixed, 95\% CI) & Totals not selected \\
\hline 18 Electrolyte level & 1 & & Mean Difference (IV, Fixed, 95\% CI) & Totals not selected \\
\hline 18.1 Sodium & 1 & & Mean Difference (IV, Fixed, 95\% CI) & $0.0[0.0,0.0]$ \\
\hline 19 Markers of renal function & 2 & & Mean Difference (IV, Fixed, 95\% Cl) & Subtotals only \\
\hline 19.1 Urea & 1 & 67 & Mean Difference (IV, Fixed, 95\% CI) & $-11.29[-24.69,2.11]$ \\
\hline 19.2 Creatinine & 2 & 138 & Mean Difference (IV, Fixed, 95\% CI) & $-0.08[-0.33,0.16]$ \\
\hline
\end{tabular}


Analysis 2.1. Comparison 2 Intravenous versus subcutaneous access, Outcome 1 Insertion failures.

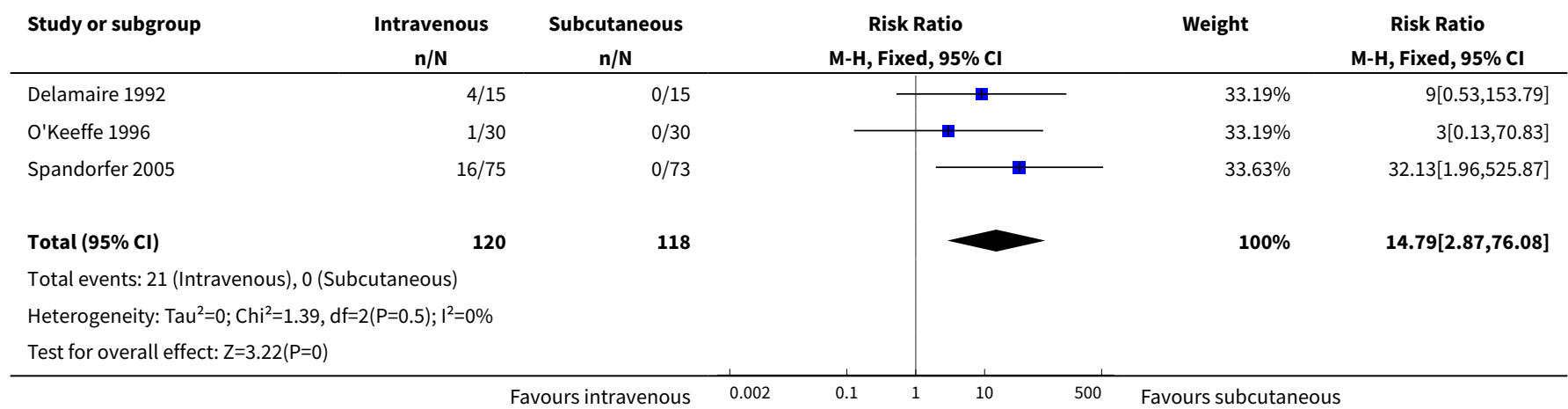

Analysis 2.2. Comparison 2 Intravenous versus subcutaneous access, Outcome 2 Insertion failures (sensitivity analysis - trial(s) with adequate allocation concealment).

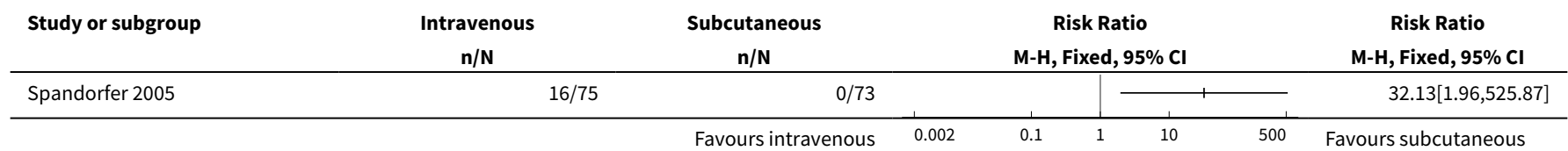

Analysis 2.3. Comparison 2 Intravenous versus subcutaneous access, Outcome 3 Insertion failures (subgroup analysis child vs adult).

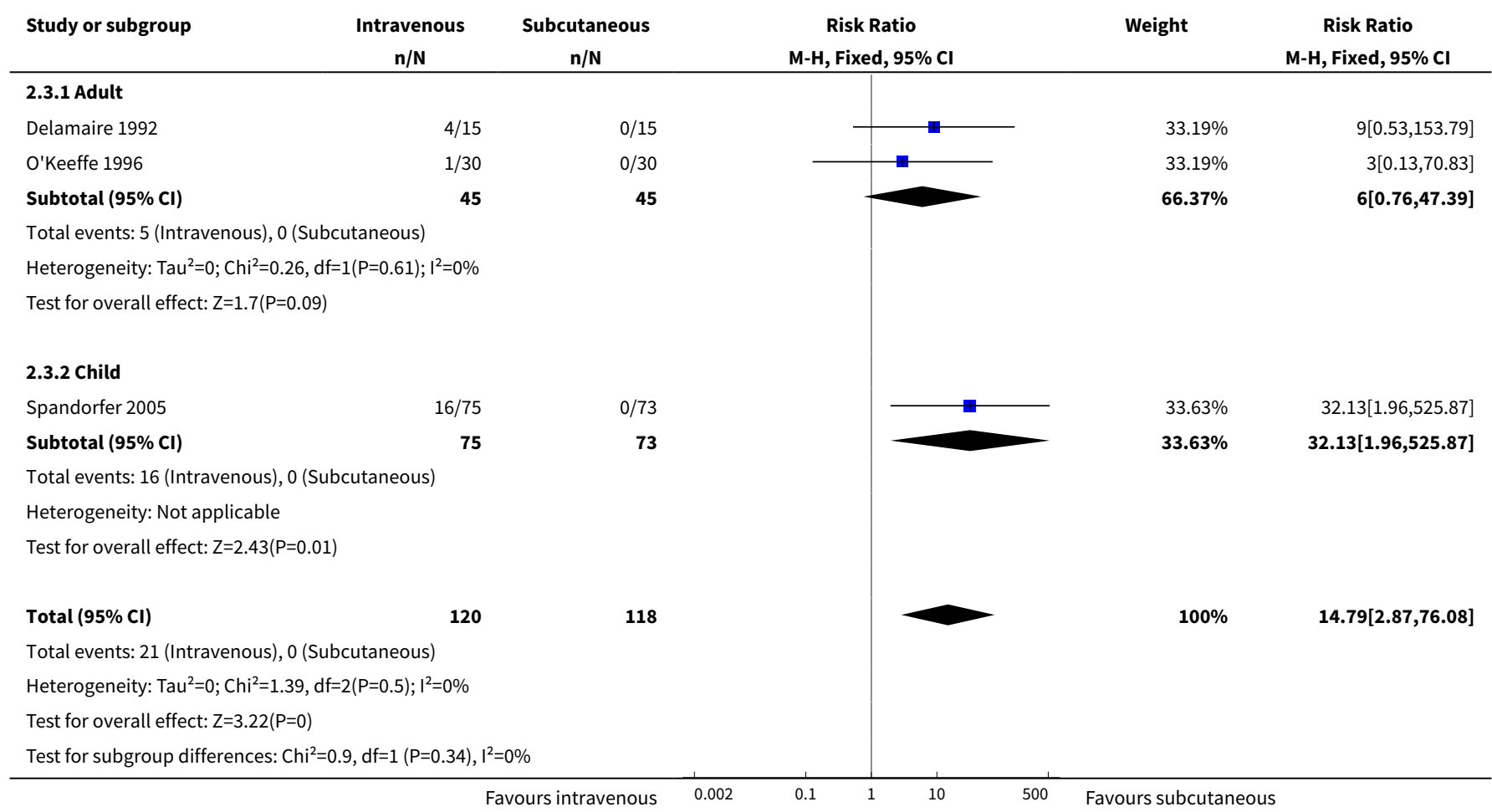


Analysis 2.4. Comparison 2 Intravenous versus subcutaneous access, Outcome 4 Time to infusion/placement.

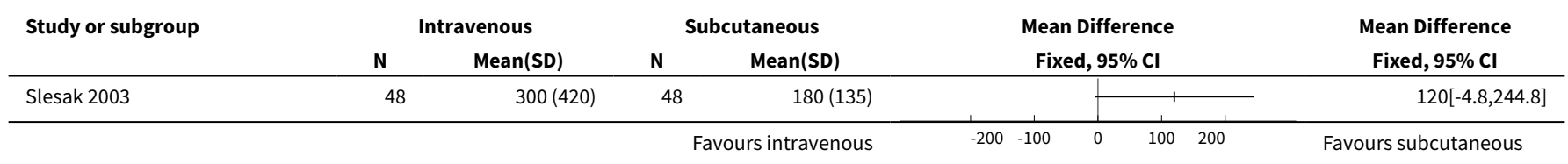

Analysis 2.5. Comparison 2 Intravenous versus subcutaneous access, Outcome 5 Dislodgement of device during infusion.

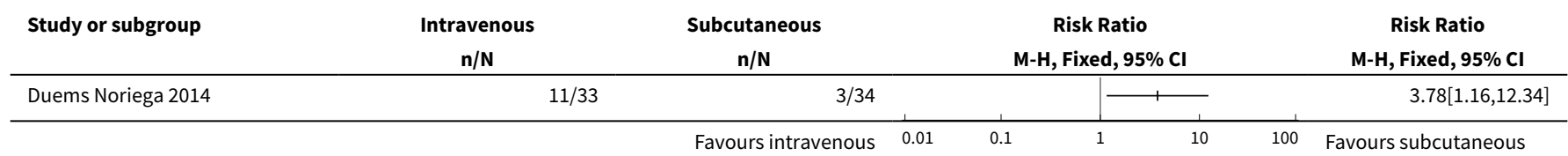

Analysis 2.6. Comparison 2 Intravenous versus subcutaneous access, Outcome 6 Time with functional access (days).

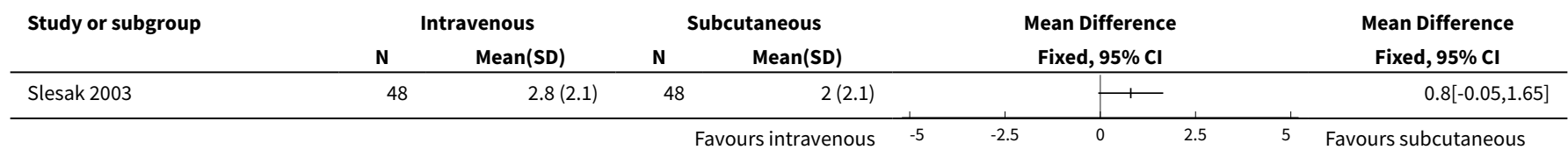

Analysis 2.7. Comparison 2 Intravenous versus subcutaneous access, Outcome 7 Local site reactions.

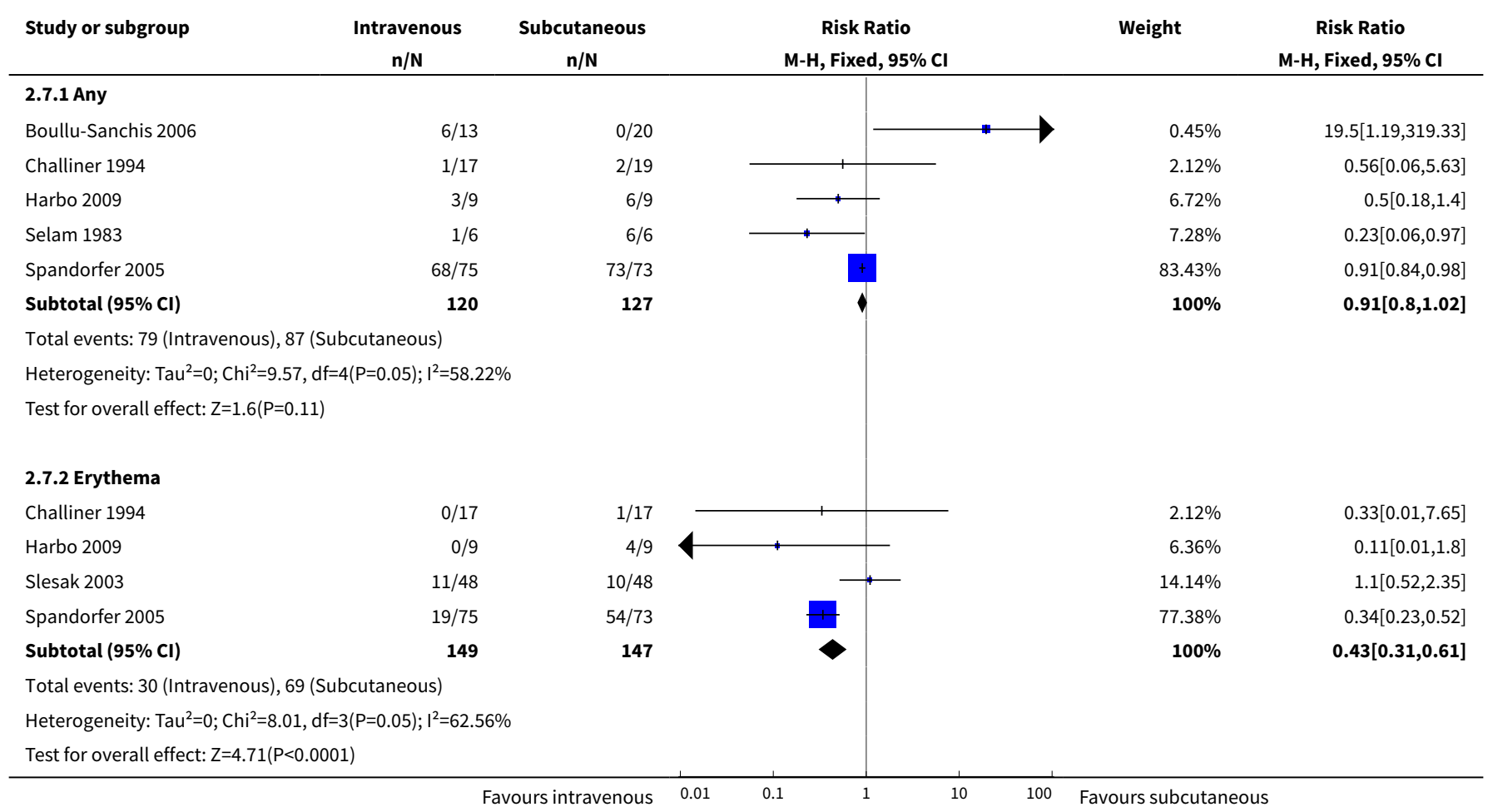




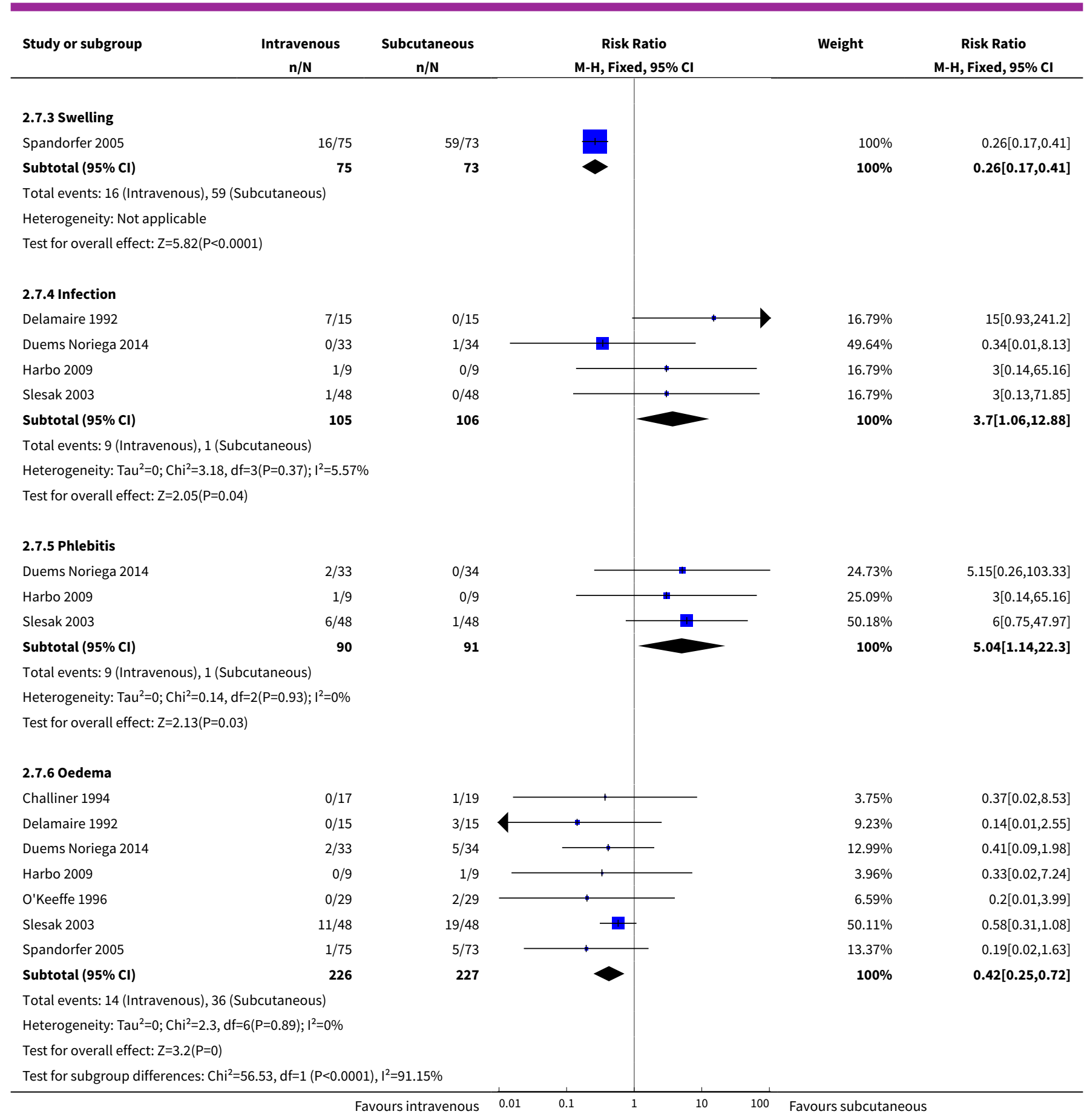

\section{Analysis 2.8. Comparison 2 Intravenous versus subcutaneous access, Outcome 8 Local site reactions (sensitivity analysis - trial(s) with adequate allocation concealment).}

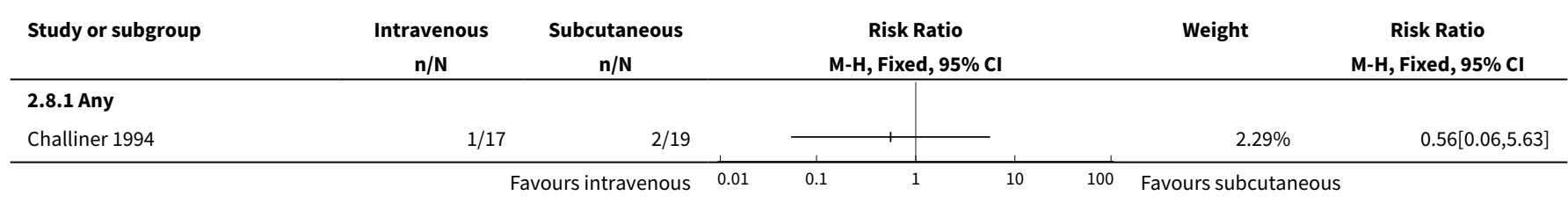




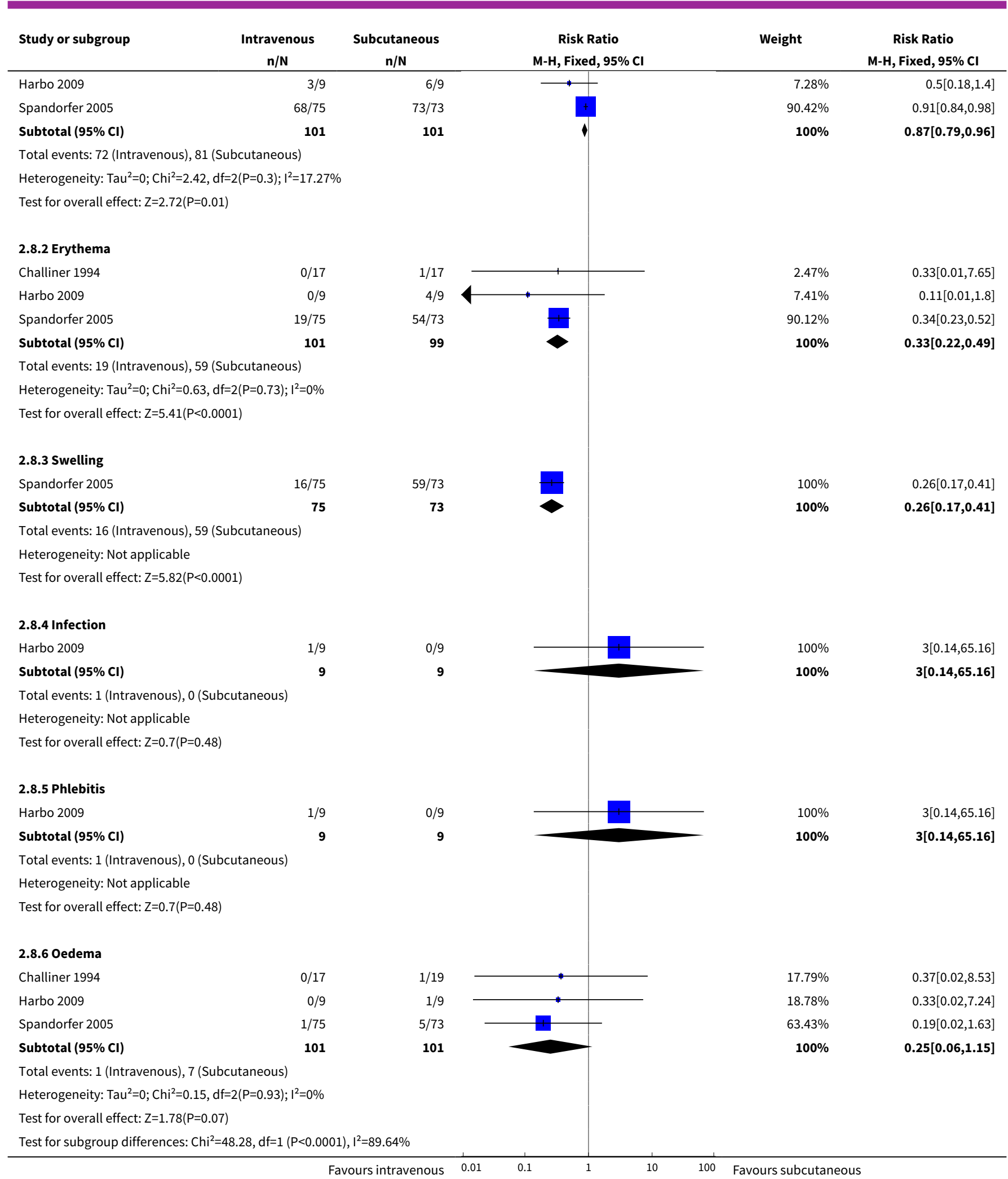


Analysis 2.9. Comparison 2 Intravenous versus subcutaneous access, Outcome 9 Clinicians' scores of feasibility of insertion.

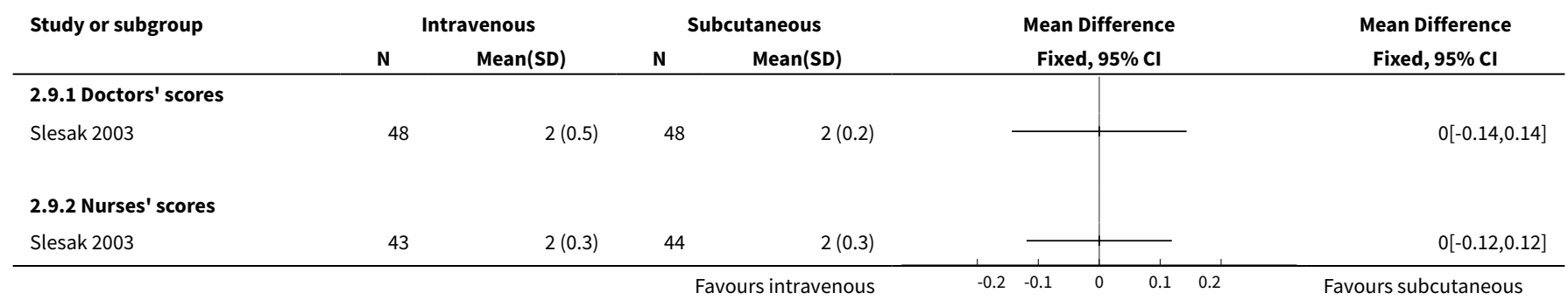

Analysis 2.10. Comparison 2 Intravenous versus subcutaneous access, Outcome 10 Clinician's perception of difficulty of insertion.

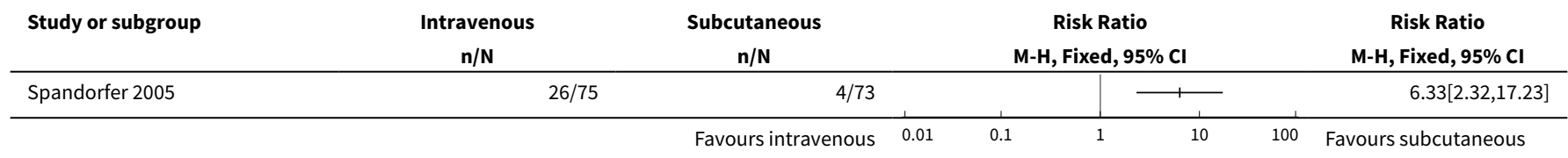

\section{Analysis 2.11. Comparison 2 Intravenous versus subcutaneous access, Outcome 11 Patients' discomfort.}

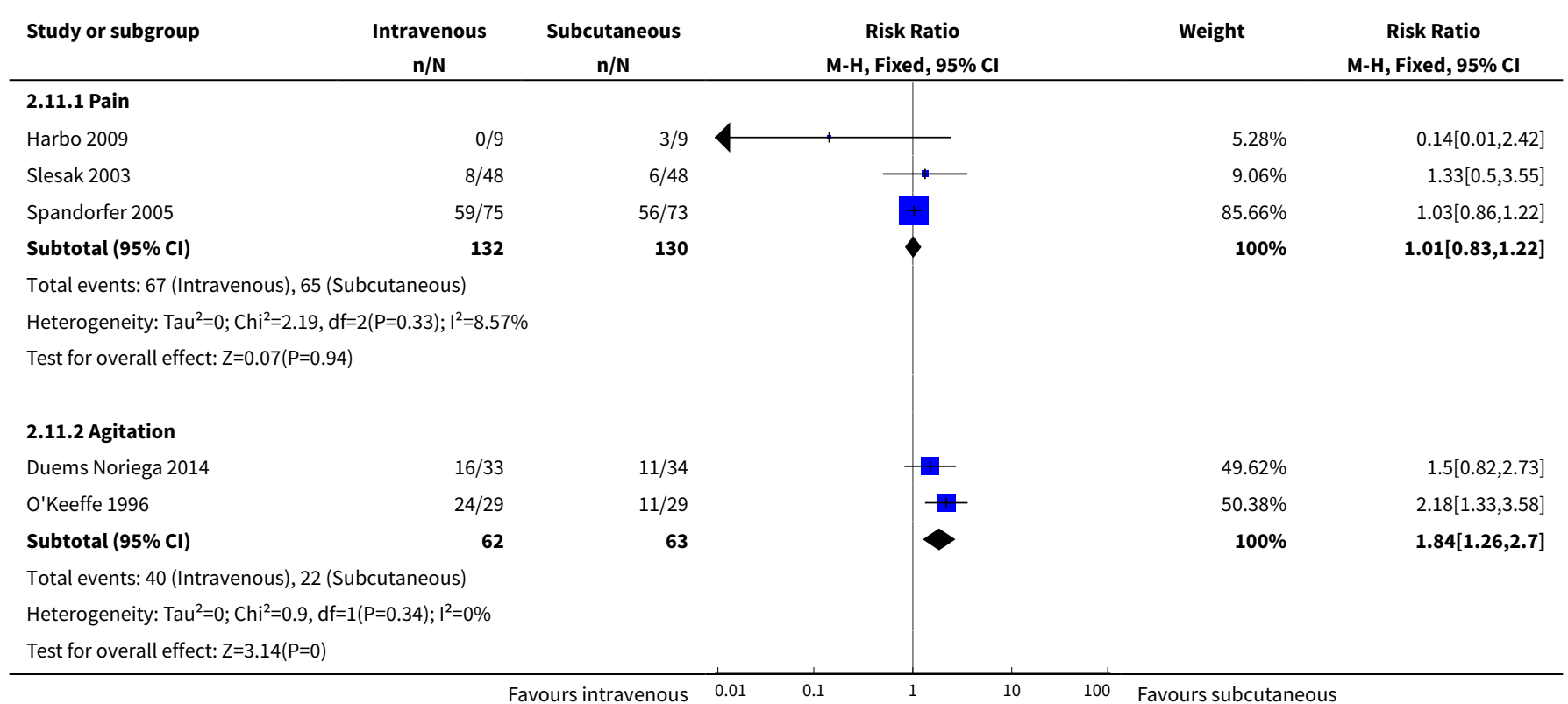


Analysis 2.12. Comparison 2 Intravenous versus subcutaneous access, Outcome 12

Patients' discomfort (sensitivity analysis - trial(s) with adequate allocation concealment).

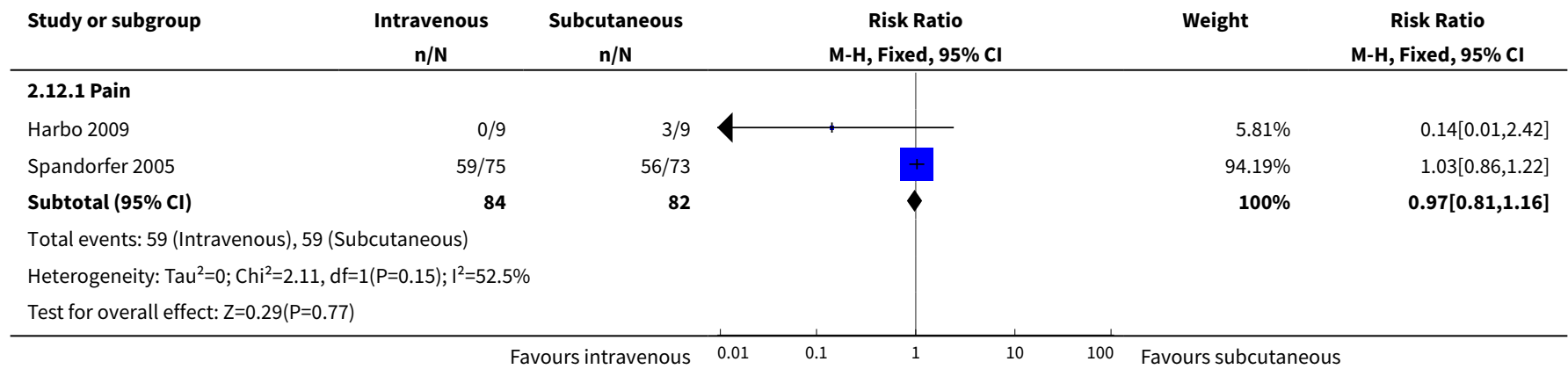

Analysis 2.13. Comparison 2 Intravenous versus subcutaneous access, Outcome 13 Patient discomfort score.

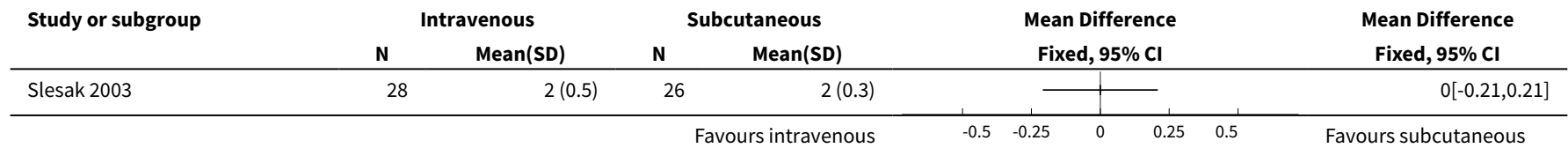

Analysis 2.14. Comparison 2 Intravenous versus subcutaneous access, Outcome 14 Mortality.

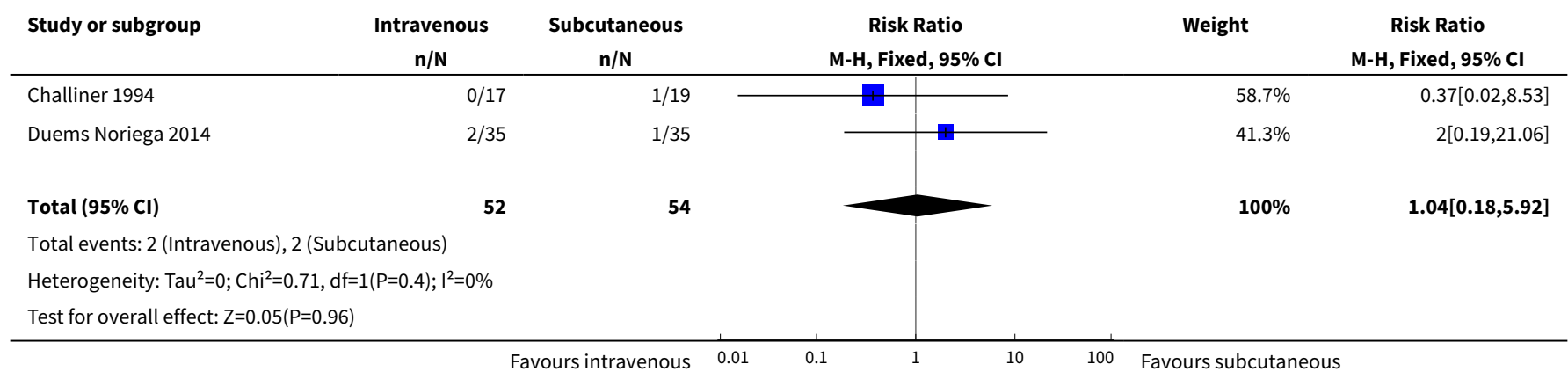

Analysis 2.15. Comparison 2 Intravenous versus subcutaneous access, Outcome 15 Mortality (sensitivity analysis - trial(s) with adequate allocation concealment).

\begin{tabular}{|c|c|c|c|c|c|c|c|}
\hline \multirow{2}{*}{$\begin{array}{l}\text { Study or subgroup } \\
\text { Challiner } 1994\end{array}$} & $\begin{array}{c}\text { Intravenous } \\
n / N \\
\end{array}$ & $\begin{array}{c}\text { Subcutaneous } \\
n / N \\
\end{array}$ & & \multicolumn{2}{|c|}{$\begin{array}{c}\text { Risk Ratio } \\
\text { M-H, Fixed, 95\% CI }\end{array}$} & & \multirow{2}{*}{$\begin{array}{c}\text { Risk Ratio } \\
\text { M-H, Fixed, 95\% Cl } \\
0.37[0.02,8.53]\end{array}$} \\
\hline & $0 / 17$ & $1 / 19$ & & 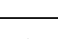 & $\begin{array}{l} \\
\end{array}$ & & \\
\hline
\end{tabular}


Analysis 2.16. Comparison 2 Intravenous versus subcutaneous access, Outcome 16 Volume of fluids transfused.

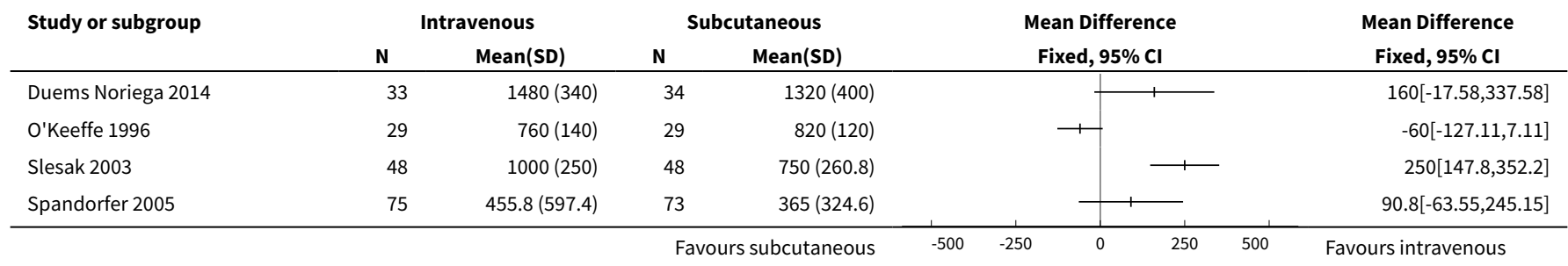

Analysis 2.17. Comparison 2 Intravenous versus subcutaneous access, Outcome 17 Volume of fluids transfused (sensitivity analysis - trial(s) with adequate allocation).

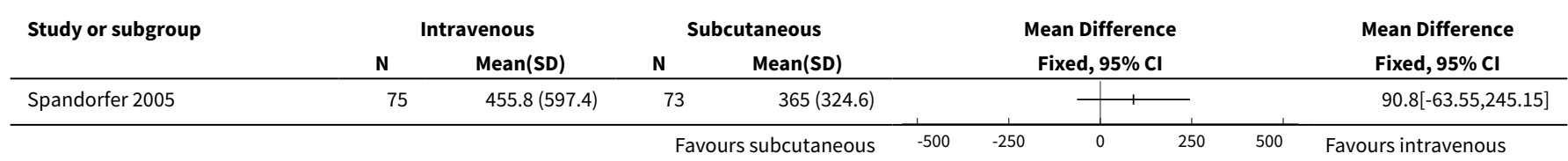

Analysis 2.18. Comparison 2 Intravenous versus subcutaneous access, Outcome 18 Electrolyte level.

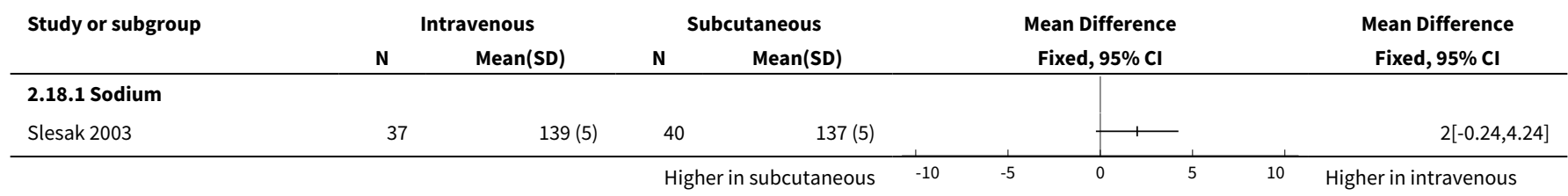

Analysis 2.19. Comparison 2 Intravenous versus subcutaneous access, Outcome 19 Markers of renal function.

\begin{tabular}{|c|c|c|c|c|c|c|c|}
\hline \multirow[t]{2}{*}{ Study or subgroup } & \multicolumn{2}{|c|}{ Intravenous } & \multicolumn{2}{|c|}{ Subcutaneous } & \multirow{2}{*}{$\begin{array}{c}\text { Mean Difference } \\
\text { Fixed, } 95 \% \mathrm{Cl}\end{array}$} & \multirow[t]{2}{*}{ Weight } & \multirow{2}{*}{$\begin{array}{c}\text { Mean Difference } \\
\text { Fixed, } 95 \% \mathrm{Cl}\end{array}$} \\
\hline & $\mathbf{N}$ & $\operatorname{Mean}(S D)$ & $\mathbf{N}$ & Mean(SD) & & & \\
\hline \multicolumn{8}{|l|}{ 2.19.1 Urea } \\
\hline Duems Noriega 2014 & 33 & $52.3(23.8)$ & 34 & $63.6(31.7)$ & & $100 \%$ & $-11.29[-24.69,2.11]$ \\
\hline 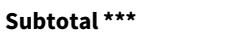 & 33 & & 34 & & & $100 \%$ & $-11.29[-24.69,2.11]$ \\
\hline \multicolumn{8}{|c|}{ Heterogeneity: Not applicable } \\
\hline \multicolumn{8}{|c|}{ Test for overall effect: $Z=1.65(P=0.1)$} \\
\hline \multicolumn{8}{|l|}{ 2.19.2 Creatinine } \\
\hline Duems Noriega 2014 & 33 & $0.6(0.5)$ & 34 & $0.7(0.7)$ & & $79.85 \%$ & $-0.08[-0.36,0.2]$ \\
\hline Slesak 2003 & 31 & $0.8(0.7)$ & 40 & $0.9(1.6)$ & . & $20.15 \%$ & $-0.1[-0.65,0.45]$ \\
\hline Subtotal $\star \star \star$ & 64 & & 74 & & & $100 \%$ & $-0.08[-0.33,0.16]$ \\
\hline \multicolumn{8}{|c|}{ Heterogeneity: $\operatorname{Tau}^{2}=0 ; \mathrm{Chi}^{2}=0, \mathrm{df}=1(\mathrm{P}=0.95) ; \mathrm{I}^{2}=0 \%$} \\
\hline \multicolumn{8}{|c|}{ Test for overall effect: $Z=0.66(P=0.51)$} \\
\hline
\end{tabular}


Comparison 3. Saphenous vein cutdown versus intraosseous access

\begin{tabular}{lllll}
\hline Outcome or subgroup title & No. of studies & $\begin{array}{l}\text { No. of partici- } \\
\text { pants }\end{array}$ & Statistical method & Effect size \\
\hline 1 Insertion failures & 1 & Risk Ratio (M-H, Fixed, 95\% Cl) & Totals not selected \\
\hline $\begin{array}{l}\text { 2 Time to infusion/placement } \\
\text { (seconds) }\end{array}$ & 1 & $\begin{array}{l}\text { Mean Difference (Fixed, 95\% } \\
\mathrm{Cl})\end{array}$ & Totals not selected \\
\hline
\end{tabular}

\section{Analysis 3.1. Comparison 3 Saphenous vein cutdown versus intraosseous access, Outcome 1 Insertion failures.}

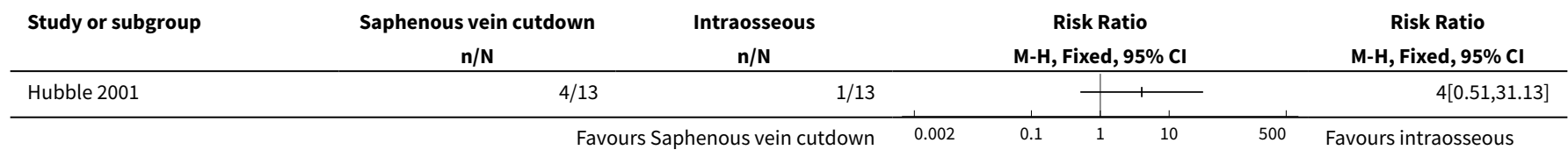

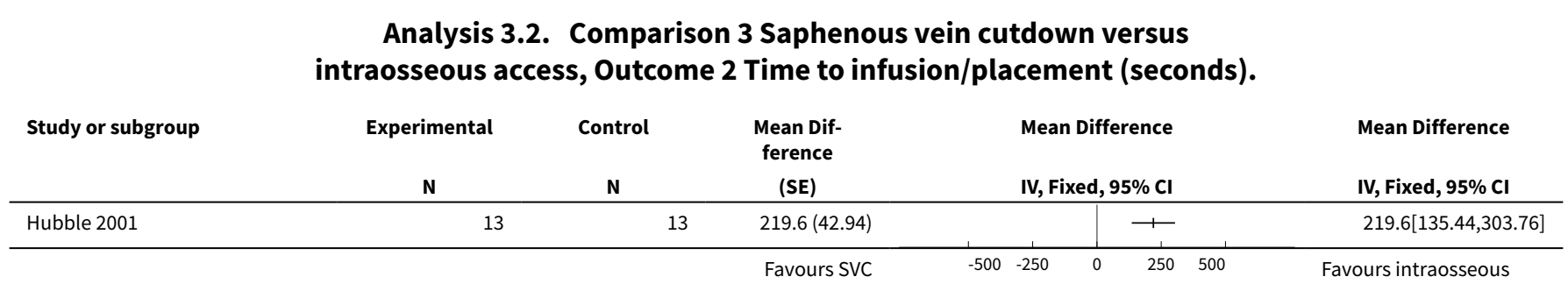

\section{AP P E N DICES}

\section{Appendix 1. Search strategies}

\section{Cochrane Injuries Group Specialised Register \& Cochrane Central Register of Controlled Trials (CENTRAL, The Cochrane Library)}

\#1((Intravenous or venous) ADJ3 (route ${ }^{\star}$ or access ${ }^{\star}$ or insert $^{\star}$ or device or method $^{\star}$ or fluid ${ }^{\star}$ or therap $^{\star}$ or administer $^{\star}$ or administrat $^{\star}$ or $^{*}$ infus $^{\star}$ or dehydrat* ${\text { or rehydrat* }{ }^{*} \text { or hydrat }{ }^{\star} \text { or drug }^{\star} \text { or medication }}^{\star})): \mathrm{TI}, \mathrm{AB}, \mathrm{KY}$

\#2MESH DESCRIPTOR Infusions, Intravenous

\#3\#1 OR \#2

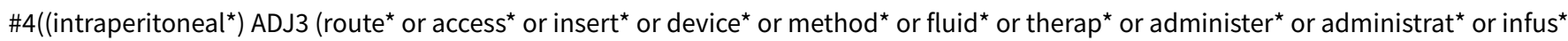
or dehydrat* or hydrat ${ }^{\star}$ or rehydrat ${ }^{\star}$ or drug* $^{\star}$ or medication $\left.\left.{ }^{\star}\right)\right): T \mathrm{TI}, \mathrm{AB}, \mathrm{KY}$

\#5MESH DESCRIPTOR Infusions, Intraosseous

\#6(intraosseous ${ }^{\star}$ ) ADJ3 (route* or access ${ }^{\star}$ or insert ${ }^{\star}$ or device ${ }^{\star}$ or method ${ }^{\star}$ or fluid ${ }^{\star}$ or therap ${ }^{\star}$ or administer ${ }^{\star}$ or administrat ${ }^{\star}$ or infus ${ }^{\star}$ or dehydrat $^{\star}$ or rehydrat ${ }^{\star}$ or hydrat* or drug $^{\star}$ or medication*)

\#7\#5 OR \#6

\#8MESH DESCRIPTOR Infusions, Subcutaneous

\#9MESH DESCRIPTOR Hypodermoclysis

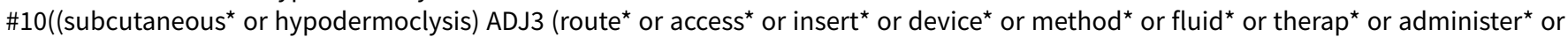
administrat ${ }^{\star}$ or infus* or dehydrat* $^{\star}$ or rehydrat* or hydrat $^{\star}$ or drug $^{\star}$ or medication $\left.\left.{ }^{\star}\right)\right): \mathrm{TI}, \mathrm{AB}, \mathrm{KY}$

\#11\#8 OR \#9 OR \#10

\#12\#4 OR \#7 OR \#11

\#13\#3 AND \#12

\#14\#3 OR \#7 OR \#11

\#15\#4 AND \#14 
\#16\#3 OR \#4 OR \#11

$\# 17 \# 7$ AND \#16

\#18\#3 OR \#4 OR \#7

\#19\#11 AND \#18

\#20\#13 OR \#15 OR \#17 OR \#19

\#21* NOT INMEDLINE NOT INEMBASE

\#22\#20 AND \#21

\section{Ovid MEDLINE(R) In-Process \& Other Non-Indexed Citations, Ovid MEDLINE(R) Daily, Ovid MEDLINE(R) and Ovid OLDMEDLINE(R)}

1. Infusions, Intravenous/

2. (("intra?venous ${ }^{\star}$ or venous) adj3 (route* or access* or insert* or device* or method ${ }^{\star}$ or fluid* or therap* or administer* or administrat* or infus ${ }^{\star}$ or dehydrat* or rehydrat $^{\star}$ or hydrat $^{\star}$ or drug* $^{\star}$ or medication*)).ab,ti.

3. 1 or 2

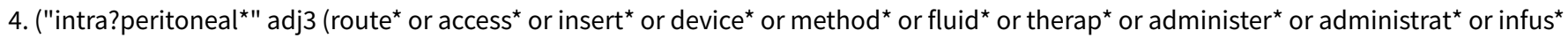
or dehydrat ${ }^{\star}$ or hydrat* or rehydrat* ${ }^{\star}$ or drug* or medication $\left.{ }^{\star}\right)$ ).ab,ti.

5. Infusions, Intraosseous/

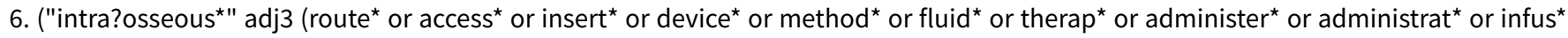
or dehydrat* ${ }^{\star}$ or rehydrat* or hydrat* ${ }^{\star}$ or drug* or medication $\left.{ }^{\star}\right)$ ).ab,ti.

7.5 or 6

8. infusions, subcutaneous/ or hypodermoclysis/

9. ((subcutaneous ${ }^{\star}$ or subcut or hypodermoclysis) adj3 (route* or access* or insert* or device* or method ${ }^{\star}$ or fluid $^{\star}$ or therap $^{\star}$ or administer ${ }^{\star}$ or administrat ${ }^{\star}$ or infus ${ }^{\star}$ or dehydrat ${ }^{\star}$ or rehydrat ${ }^{\star}$ or hydrat ${ }^{\star}$ or drug $^{\star}$ or medication $\left.\left.{ }^{\star}\right)\right)$.ab,ti.

10. 8 or 9

11.4 or 7 or 10

12. 3 and 11

13. 3 or 7 or 10

14.4 and 13

15. 3 or 4 or 10

16. 7 and 15

17. 3 or 4 or 7

18. 10 and 17

19. 12 or 14 or 16 or 18

20. randomi?ed.ab,ti.

21. randomized controlled trial.pt.

22. controlled clinical trial.pt.

23. placebo.ab.

24. clinical trials as topic.sh.

25. randomly.ab.

26. trial.ti.

27. Comparative Study/

28.20 or 21 or 22 or 23 or 24 or 25 or 26 or 27

29. (animals not (humans and animals)).sh.

30. 28 not 29

31. 19 and 30

\section{Embase + Embase Classic}

1. Infusions, Intravenous/

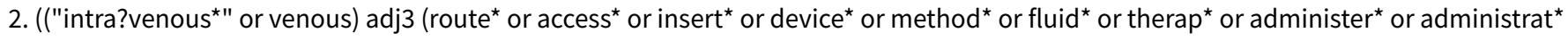

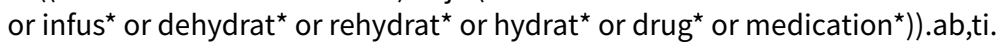

3. 1 or 2

4. ("intra?peritoneal ${ }^{\star}$ adj3 (route* or access ${ }^{\star}$ or insert* or device* or method* or fluid $^{\star}$ or therap* or administer $^{\star}$ or administrat ${ }^{\star}$ or infus ${ }^{\star}$ or dehydrat* or hydrat* or rehydrat* or drug* or medication*)).ab,ti.

5. Infusions, Intraosseous/

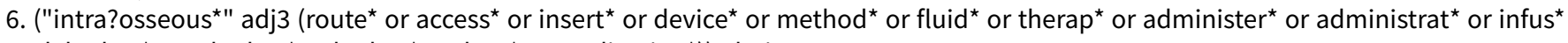
or dehydrat* or rehydrat* or hydrat* or drug* or medication*)).ab,ti.

7.5 or 6

8. infusions, subcutaneous/ or hypodermoclysis/

9. ((subcutaneous ${ }^{\star}$ or subcut or hypodermoclysis) adj3 (route* or access ${ }^{\star}$ or insert ${ }^{\star}$ or device* or method $^{\star}$ or fluid $^{\star}$ or therap $^{\star}$ or administer ${ }^{\star}$ or administrat ${ }^{\star}$ or infus $^{\star}$ or dehydrat ${ }^{\star}$ or rehydrat* or hydrat $^{\star}$ or drug $^{\star}$ or medication $\left.{ }^{\star}\right)$ ).ab,ti.

10. 8 or 9

11.4 or 7 or 10

Comparison of routes for achieving parenteral access with a focus on the management of patients with Ebola virus disease (Review) 
12. 3 and 11

13. 3 or 7 or 10

14.4 and 13

15.3 or 4 or 10

16.7 and 15

17. 3 or 4 or 7

18. 10 and 17

19. 12 or 14 or 16 or 18

20. exp Randomized Controlled Trial/

21. exp controlled clinical trial/

22. exp controlled study/

23. comparative study/

24. randomi?ed.ab,ti.

25. placebo.ab.

26. *Clinical Trial/

27. exp major clinical study/

28. randomly.ab.

29. (trial or study).ti.

30.20 or 21 or 22 or 24 or 25 or 26 or 27 or 28 or 29

31. exp animal/ not (exp human/ and exp animal/)

32. 30 not 31

33. 19 and 32

34. limit 33 to exclude medline journals

CINAHL Plus (EBSCO)

\begin{tabular}{|c|c|}
\hline S1 & (MH "Clinical Trials") \\
\hline S2 & PT clinical trial* \\
\hline S3 & TX clinical N3 trial ${ }^{*}$ \\
\hline S4 & 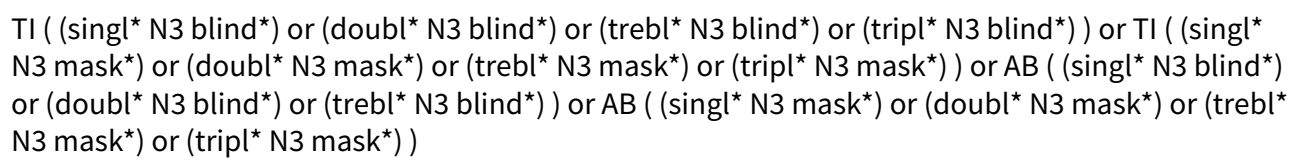 \\
\hline S5 & TX randomi?ed N3 control ${ }^{\star} \mathrm{N} 3$ trial $^{*}$ \\
\hline S6 & (MH "Placebos") \\
\hline S7 & TX placebo* \\
\hline S8 & (MH "Random Assignment") \\
\hline S9 & TX random* N3 allocat* \\
\hline S10 & MH quantitative studies \\
\hline S11 & $\mathrm{S} 1$ or $\mathrm{S} 2$ or $\mathrm{S} 3$ or $\mathrm{S} 4$ or $\mathrm{S} 5$ or $\mathrm{S} 6$ or $\mathrm{S} 7$ or $\mathrm{S} 8$ or $\mathrm{S} 9$ or $\mathrm{S} 10$ \\
\hline S12 & (MH "Infusions, Intravenous") \\
\hline S13 & 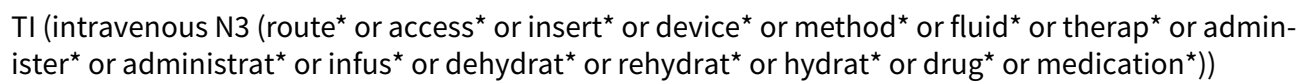 \\
\hline
\end{tabular}




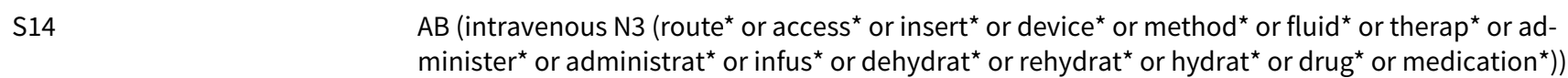

\section{S15}

S12 OR S13 OR S14

S16

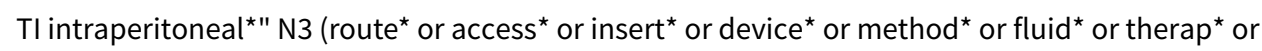
administer ${ }^{\star}$ or administrat* or infus $^{\star}$ or dehydrat ${ }^{\star}$ or hydrat* ${ }^{\star}$ or rehydrat* or drug $^{\star}$ or medication*)

$\mathrm{S} 17$

AB intraperitoneal ${ }^{\star \star}$ N3 (route or access $^{*}$ or insert ${ }^{*}$ or device ${ }^{\star}$ or method $^{*}$ or fluid ${ }^{\star}$ or therap* or administer ${ }^{\star}$ or administrat ${ }^{\star}$ or infus ${ }^{\star}$ or dehydrat ${ }^{\star}$ or hydrat ${ }^{\star}$ or rehydrat ${ }^{\star}$ or drug* ${ }^{\star}$ or medication*)

\begin{tabular}{|c|c|}
\hline S18 & S16 OR S17 \\
\hline S19 & (MH "Infusions, Intraosseous") \\
\hline S20 & 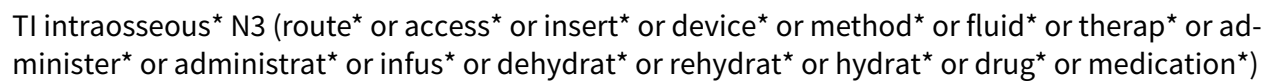 \\
\hline
\end{tabular}

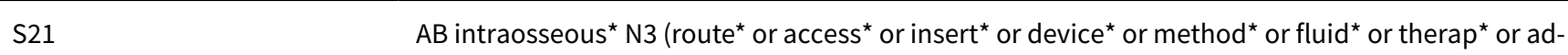
minister ${ }^{\star}$ or administrat ${ }^{*}$ or infus ${ }^{*}$ or dehydrat ${ }^{*}$ or rehydrat ${ }^{\star}$ or hydrat ${ }^{*}$ or drug* ${ }^{*}$ or medication ${ }^{\star}$ )

\begin{tabular}{|c|c|}
\hline S22 & S19 OR S20 OR S21 \\
\hline S23 & (MH "Infusions, Subcutaneous") \\
\hline S24 & (MH "Hypodermoclysis") \\
\hline S25 & $\begin{array}{l}\text { TI (subcutaneous }{ }^{\star} \text { or hypodermoclysis) N3 (route } \text { or access }^{*} \text { or insert } \text { or device }^{*} \text { or method } \text { or }^{*} \\
\text { fluid } \\
\text { drug }^{\star} \text { or therap medication }{ }^{\star} \text { ) }\end{array}$ \\
\hline
\end{tabular}

S26

AB (subcutaneous* or hypodermoclysis) N3 (route* or access ${ }^{\star}$ or insert ${ }^{\star}$ or device ${ }^{\star}$ or method ${ }^{\star}$ or fluid $^{\star}$ or therap* or administer* or administrat ${ }^{*}$ or infus ${ }^{*}$ or dehydrat* ${ }^{\star}$ or rehydrat ${ }^{\star}$ or hydrat ${ }^{\star}$ or drug $^{*}$ or medication ${ }^{*}$ )

\begin{tabular}{ll}
\hline S27 & S23 OR S24 OR S25 OR S26 \\
\hline S28 & S18 OR S22 OR S27 \\
\hline S29 & S15 AND S28 \\
\hline S30 & S15 OR S22 OR S27 \\
\hline S31 & S18 AND S30 \\
\hline S32 & S15 OR S18 OR S27 \\
\hline S33 & S22 AND S32 \\
\hline S34 & S15 OR S18 OR S22 \\
\hline S35 & S27 AND S34 \\
\hline S36 & S29 OR S31 OR S33 OR S35 \\
\hline S37 & S11 AND S36 Limiters - Exclude MEDLINE records \\
\hline
\end{tabular}

Comparison of routes for achieving parenteral access with a focus on the management of patients with Ebola virus disease (Review) 


\section{Clinicaltrials.gov}

( subcutaneous OR rectal OR proctoclysis OR intraosseous ) AND INFLECT EXACT "Interventional" [STUDY-TYPES] AND fluids [TREATMENT]

\section{Appendix 2. Formulae to estimate mean and standard deviation from median, range and sample size as recommended by Hozo et al}

\section{Estimation of mean}

If sample size is $>25$, median can be used to estimate mean.

\section{Estimation of standard deviation (SD)}

If moderate sample size $(15<\mathrm{n} \leq 70)$ estimated $\mathrm{SD}=$ range $/ 4$.

If large sample size $(n>70)$ estimated SD = range/6.

(Hozo 2005).

WHAT'S NEW

\begin{tabular}{lll}
\hline Date & Event & Description \\
\hline 22 May 2015 & Amended & Acknowledgement added \\
\hline
\end{tabular}

\section{CONTRIBUTIONS OF AUTHORS}

All authors contributed to the development of the protocol and the review.

\section{DECLARATIONS OF INTEREST}

KK, GT, DB and HS have no known conflicts of interest.

AP: My institution receives financial support for trials from Fresenius Kabi and CSL Behring.

TH: My institution receives financial support for trials from Fresenius Kabi and CSL Behring.

IR: We (the Cochrane Injuries Group) received a small grant from The Cochrane Collaboration to complete this Cochrane Review.

\section{SOURCES OF SUPPORT}

\section{Internal sources}

- Clinical Trials Unit, London School of Hygiene \& Tropical Medicine, UK.

- National Institute for Health Research, UK.

The Cochrane Injuries Group editorial base is supported by funds from the NIHR and Professor lan Roberts is a recipient of a NIHR Senior Investigator Award.

\section{External sources}

- The Cochrane Collaboration, UK.

The Cochrane Editorial Unit provided financial support towards the completion of this review and the accompanying film.

\section{DIFFERENCES BETWEEN PROTOCOLANDREVIEW}

We added further details to the Types of studies and Types of participants sections. These changes do not represent a change in the inclusion criteria between the protocol and review, but have been made based on the recommendations in editorial comments on the completed review to improve clarity.

We have included a paragraph to describe how data from cluster-randomised controlled trials would be included in the analysis. 
At the request of the Cochrane Editorial Unit editors, we refined the outcomes included in the 'Summary of findings' tables and GRADE assessment. Rather than including all outcomes as originally proposed, only outcomes most closely aligned with the objectives of the review are included (success of route of placement; time to placement/start of infusion; dislodgement of device during infusion; volume of fluid infused and needlestick injuries).

\section{NDEX TERMS}

\section{Medical Subject Headings (MeSH)}

Dehydration [etiology] [*therapy]; Disease Management; Hemorrhagic Fever, Ebola [ ${ }^{*}$ complications]; Hypodermoclysis; Infusions, Intraosseous; Infusions, Intravenous; Infusions, Parenteral [ ${ }^{\star}$ methods]; Saphenous Vein

\section{MeSH check words}

Humans 